Aus dem Department für Herz- und Kreislaufphysiologie (Direktor: Prof. Dr. Markus Hecker) der Universität Heidelberg

\title{
Endothelial cell modulation of cardiomyocyte gene expression
}

\author{
Inauguraldissertation \\ zur Erlangung des Doctor scientiarum humanarum \\ an der \\ Medizinischen Fakultät Heidelberg \\ der \\ Ruprecht-Karls-Universität
}

vorgelegt von

M.Sc. Fan Jiang

aus

Huangshan, P.R. China 
Dekan: Herr Prof. Dr. Wolfgang Herzog

Doktorvater: Herr Prof. Dr. Markus Hecker 


\section{Contents}

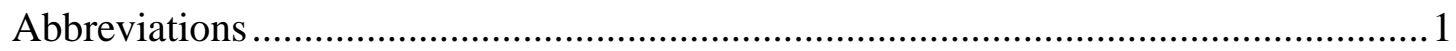

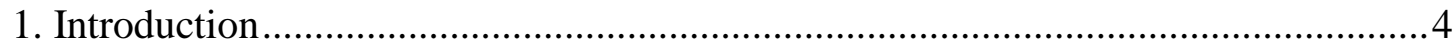

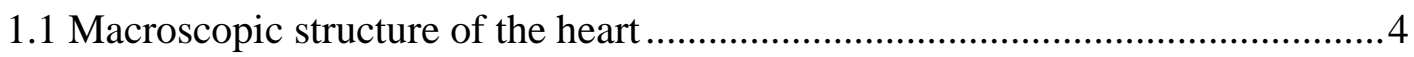

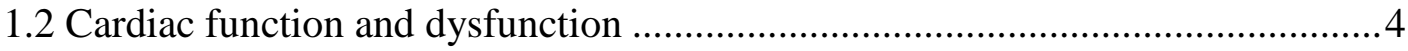

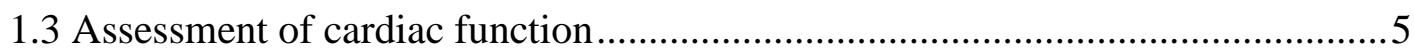

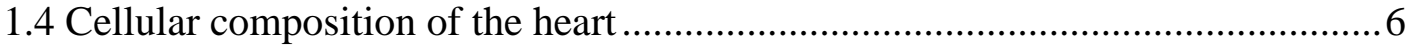

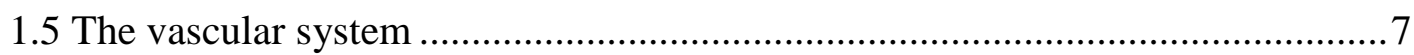

1.5.1 Macrovascular and microvascular endothelial cells ....................................

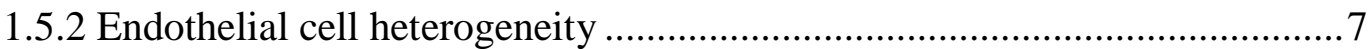

1.5.3 Endothelial cell activation and dysfunction............................................ 8

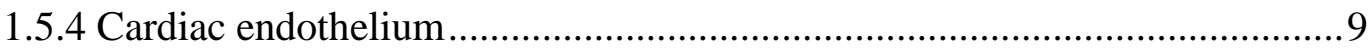

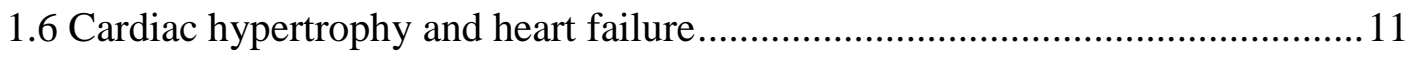

1.6.1 A brief macroscopic view of the process of cardiac hypertrophy ...............11

1.6.2 Potential circulating biomarkers during cardiac hypertrophy ....................13

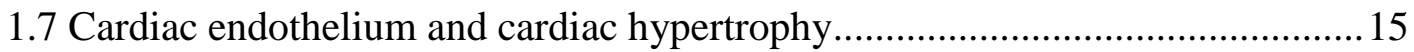

1.7.1 Angiogenesis and cardiac hypertrophy ................................................. 15

1.7.2 Endothelial cell - cardiomyocyte interaction during the process of cardiac

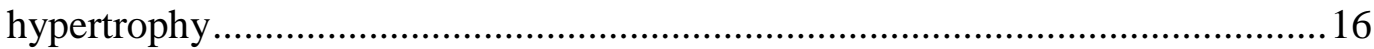

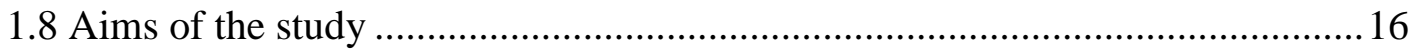

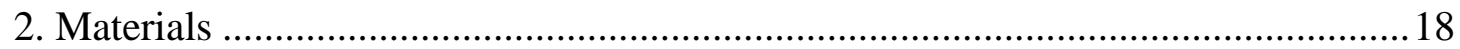

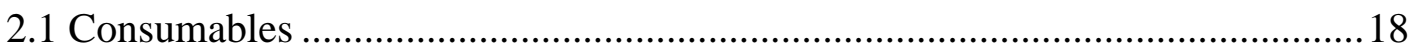

2.2 Cell culture medium and supplements ........................................................ 18

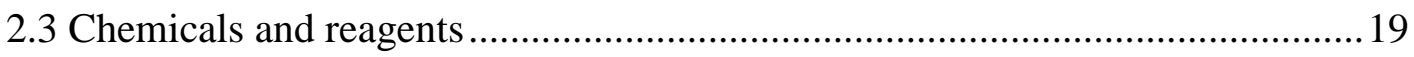

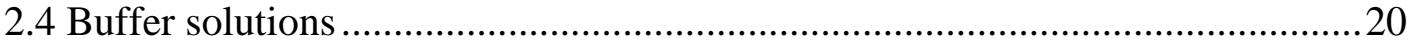

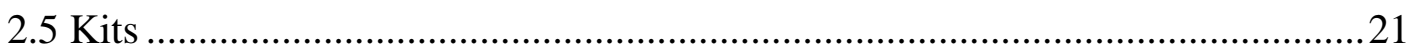

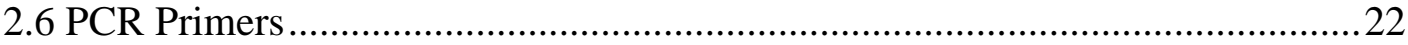

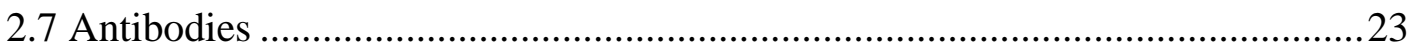

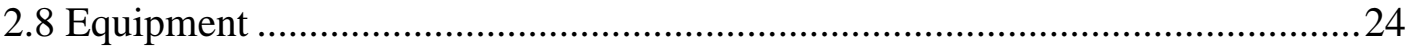

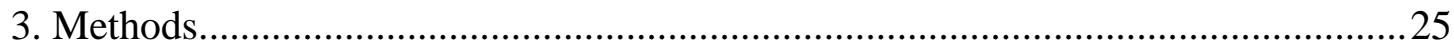




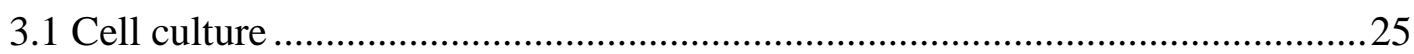

3.1.1 Endothelial cells, cardiomyocytes cell culture .......................................25

3.1.2 Endothelial cells, cardiomyocytes co-culture system ...............................25

3.1.3 Preparation of endothelial cell conditioned medium ...............................26

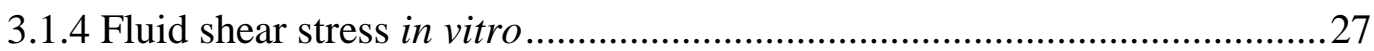

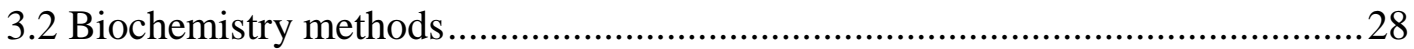

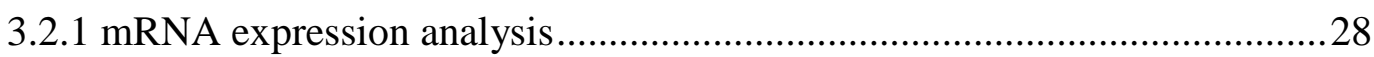

3.2.3 Cellular reactive oxygen species detection assay .....................................34

3.2.4 Extracellular nitric oxide (NO) detection assay .........................................34

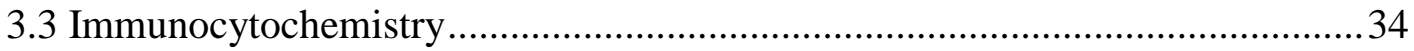

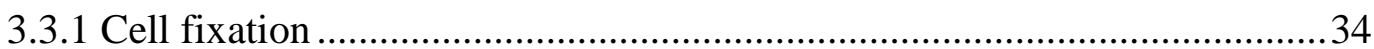

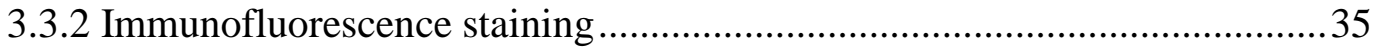

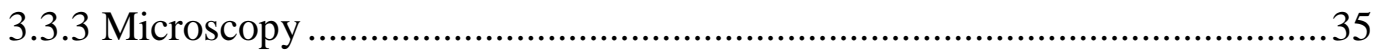

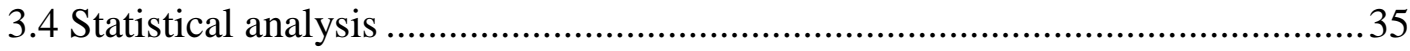

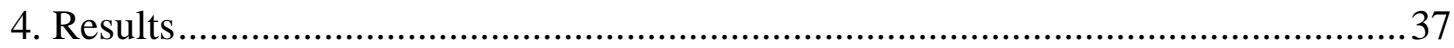

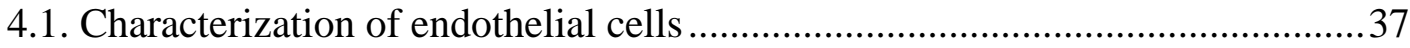

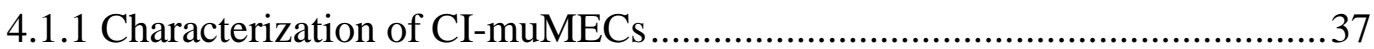

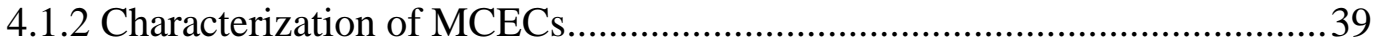

4.2 Endothelin-1 (ET-1) induced fetal gene expression in HL-1 cells.....................40

4.2.1 ET-1 induced fetal gene expression in HL-1 cells ...................................41

4.2.2 Endothelin-1 (ET-1) induced ANP peptide release into HL-1 cell culture

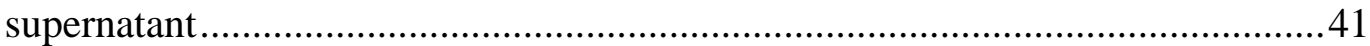

4.3 Fetal gene expression in HL-1 cells co-cultured with endothelial cells.............42

4.3.1 Morphology and permeability of the endothelial cell monolayer seeded on

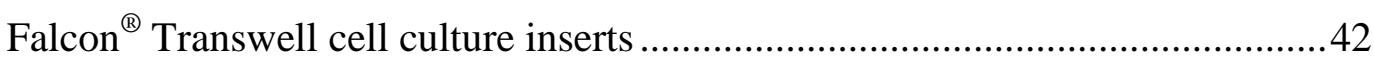

4.3.2 Fetal gene expression in HL-1 cells co-cultured with endothelial cells ......43

4.4 Fetal gene expression in HL-1 cells co-cultured with EC-conditioned medium45

4.4.1 ANP and BNP mRNA expression in HL-1 cells co-cultured with

EC-conditioned medium

4.4.2 ANP peptide release in cell culture supernatant from HL-1 cells cultured with EC-conditioned medium . .46 
4.5 Analysis of EC-conditioned medium

4.5.1 Rough fractionation of the EC-conditioned medium according to molecular mass

4.5.2 SDS-PAGE analysis of EC-conditioned medium 48

4.6 Angiopoietin-2 and endothelin-1 co-effects on fetal gene expression in HL-1 cells

4.6.1 ANP mRNA expression in HL-1 cells

4.6.2 Effects of Angiopoietin-2 on endothelin-1-stimulated ANP mRNA expression in HL-1 cells

4.6.3 ANP peptide concentration in cell culture supernatant from HL-1 cells cultured with Angiopoietin-2 and Endothelin-1

4.7 The role of nuclear factor of activated T-cells (NFAT) in endothelial cell-cardiomyocyte interaction..... 52

4.7.1 NFAT activity inhibition in endothelial cell-cardiomyocyte interaction ....52

4.7.2 Vascular endothelial growth factor C (VEGF-C) release in EC-conditioned medium

4.8 Qualitative mass spectrometry analysis of EC-conditioned medium

4.8.1 Gene ontology annotation of proteins detected in EC-conditioned medium by mass spectrometry .54

4.8.2 Gene functional classification of differently released proteins in EC-conditioned medium .56

5. Discussion 59

5.1 Characterization of endothelial cells 59

5.1.1 Characterization of CI-muMECs... 59

5.1.2 Characterization of MCECs. 60

5.2 Endothelin-1 induced fetal gene expression in HL-1 cells 61

5.3 Fetal gene expression in HL-1 cells co-cultured with endothelial cells 62

5.3.1 HL-1 cell-endothelial cell co-culture system.

5.3.2 ANP and BNP mRNA expression in HL-1 cells co-cultured with endothelial cells

5.4 Fetal gene expression in HL-1 cells co-cultured with endothelial cell conditioned medium. 


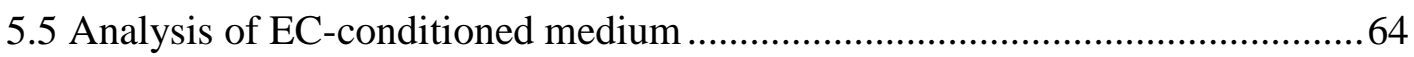

5.5.1 EC-conditioned medium fractionation by molecular weight ......................64

5.5.2 SDS-PAGE analysis of EC-conditioned medium ....................................65

5.6 Angiopoietin-2 and endothelin-1 co-effect on fetal gene expression in HL-1

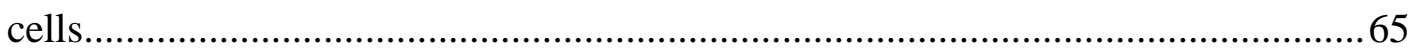

5.7 The role of NFAT in endothelial cell-cardiomyocyte interaction.....................66

5.8 Mass spectrometry analysis of EC-conditioned medium ..............................67

5.8.1 Gene ontology annotation of proteins detected in EC-conditioned medium

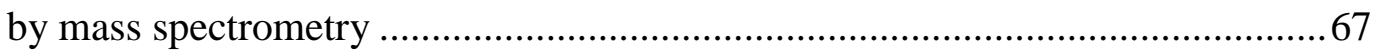

5.8.2 Gene functional classification of distinctively presented proteins in

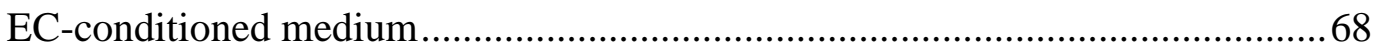

5.8.3 Pathway analysis of distinctively presented proteins in EC-conditioned

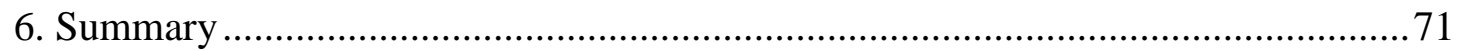

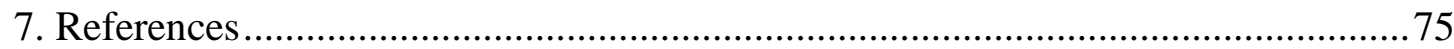

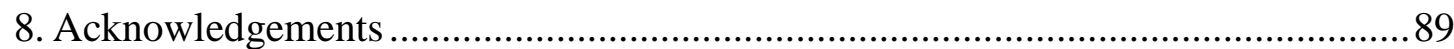


Abbreviations

\begin{tabular}{|c|c|}
\hline Ang2 & Angiopoietin-2 \\
\hline ANP & Atrial natriuretic peptide \\
\hline BNP & Brain natriuretic peptide \\
\hline cDNA & Complementary DNA \\
\hline CI-muMECs & $\begin{array}{l}\text { Functionally immortalized murine microvascular endothelial } \\
\text { cells }\end{array}$ \\
\hline DAPI & 4',6-Diamidino-2-phenylindole \\
\hline DCF-DA & 2',7'- Dichlorodihydrofluorescein diacetate \\
\hline DMSO & Dimethyl sulfoxide \\
\hline D-PBS & Dulbecco's phosphate buffered saline \\
\hline ECGS & Endothelial cell growth supplement \\
\hline ECs & Endothelial cells \\
\hline ELISA & Enzyme-linked immunosorbent assay \\
\hline ET-1 & Endothelin-1 \\
\hline FITC & Fluorescein isothiocyanate \\
\hline FK506 & Tacrolimus \\
\hline FSS & Fluid shear stress \\
\hline GFR & Glomerular filtration rate \\
\hline GO & Gene ontology \\
\hline HEPES & 4-(2-Hydroxyethyl)-1-piperazineethanesulfonic acid \\
\hline $\mathrm{HF}$ & Heart failure \\
\hline HFpEF & Heart failure with preserved ejection fraction \\
\hline HnRNPs & Heterogeneous nuclear ribonucleoproteins \\
\hline HRP & Horseradish Peroxidase \\
\hline HUVECs & Human umbilical vein endothelial cells \\
\hline ICAM-1 & Intercellular adhesion molecule 1 \\
\hline ICC & Immunocytochemistry \\
\hline
\end{tabular}




\begin{tabular}{|c|c|}
\hline $\mathrm{IFN} \gamma$ & Interferon- $\gamma$ \\
\hline IQR & Interquartile range \\
\hline LVEF & Left ventricular ejection factor \\
\hline MCECs & Mouse cardiac endothelial cells \\
\hline MCP-1 & Monocyte chemoattractant protein-1 \\
\hline miRNA & MicroRNA \\
\hline MMPs & Matrix metalloproteinases \\
\hline mRNA & Messenger RNA \\
\hline mRPL32 & Mouse 39S ribosomal protein L32 \\
\hline NFAT & Nuclear factor of activated T-cells \\
\hline$N F-\kappa B$ & $\begin{array}{l}\text { Nuclear factor kappa-light-chain-enhancer of activated B } \\
\text { cells }\end{array}$ \\
\hline NO & Nitric oxide \\
\hline NOS3 & Endothelial nitric oxide synthase \\
\hline PVDF & Polyvinylidene difluoride \\
\hline qRT-PCR & Quantitative real time polymerase chain reaction \\
\hline ROS & Reactive oxygen species \\
\hline SDS-PAGE & Sodium dodecyl sulfate polyacrylamide gel electrophoresis \\
\hline Tie 1 & $\begin{array}{l}\text { Tyrosine kinase with immunoglobulin-like and epidermal } \\
\text { growth factor-similar domains } 1\end{array}$ \\
\hline Tie2 & $\begin{array}{l}\text { Tyrosine kinase with immunoglobulin-like and growth } \\
\text { factor-similar domains } 2\end{array}$ \\
\hline TIMPs & Tissue inhibitors of metalloproteinases \\
\hline $\mathrm{TNF} \alpha$ & Tumor necrosis factor-alpha \\
\hline VCAM-1 & Vascular cell adhesion protein 1 \\
\hline VEGF-C & Vascular endothelial growth factor C \\
\hline VEGFR2 & Vascular endothelial growth factor receptor 2 \\
\hline VEGFR3 & Vascular endothelial growth factor receptor 3 \\
\hline vWF & von Willebrand factor \\
\hline
\end{tabular}


WB

Western blot

WGA

Wheat germ agglutinin

$\beta-\mathrm{MHC}$

$\beta$-Myosin heavy chain 


\section{Introduction}

\subsection{Macroscopic structure of the heart}

A normal human heart is an organ with four chambers. The upper chambers, the right and left atria, receive incoming blood. The left atrium receives oxygenated blood from the pulmonary circulation and the right atrium receives blood from the systemic circulation. The lower chambers, the more muscular right and left ventricles, pump blood out of the heart into the lungs and into the main circulation (Guyton and Hall, 2006).

\subsection{Cardiac function and dysfunction}

The heart services as a pump of the circulation, to transport nutrients and oxygen to the body tissues, to transport metabolic waste products away from the tissues, to conduct hormones through different parts of the body, and, in general, to maintain an appropriate environment in all the tissue fluids of the body for optimal survival and function of the cells (Guyton and Hall, 2006).

A reduction or damage of cardiac function could cause systemic complications. In adults with congenital heart disease, nearly all organ systems were reported to be affected (Lui et al., 2017), including decreased glomerular filtration rate (GFR) (Dimopoulos et al., 2008), a reduced forced vital capacity positively related to the complexity of the underlying heart defect in pulmonary function tests (Alonso-Gonzalez et al., 2013) and other organ dysfunctions (Alonso-Gonzalez et al., 2013, Fredriksen et al., 2001).

Kidney disease is commonly found in heart failure (HF) patients (Grande et al., 2017). It was found that GFR is associated with the degree of cardiac diastolic dysfunction and adverse clinical outcomes (Jain et al., 2017). A recent nationwide population-based cohort study showed that heart failure patients have a higher risk of developing dementia (Adelborg et al., 2017). Studies also revealed 
altered cerebral hemodynamics in heart failure. Reduced cerebral blood flow velocity and regional cerebral oxygen saturation was observed in HF patients (Mamalyga and Mamalyga, 2017, Erkelens et al., 2017).

\subsection{Assessment of cardiac function}

In 1962, Folse and Braunwald published their study about the use of a radioisotope indicator dilution technique to assess the "fraction of left ventricular volume ejected per beat' (Folse and Braunwald, 1962). This first description of a technique to measure what has subsequently been coined 'ejection fraction' heralded an era in which this single measure has become the most important metric of cardiac function utilized by clinicians (Cikes and Solomon, 2016). Factors such as exercise, diabetes, and hypertension have been reported to correlate with left ventricular ejection fraction (LVEF) (Haddadzadeh et al., 2011, Ehl et al., 2011, Georgiopoulou et al., 2013). The 2013 ACCF/AHA guidelines classify heart failure (HF) as a complex clinical syndrome that results from any structural or functional impairment of ventricular filling or ejection of blood. HF patients with a LVEF of $\geq 50 \%$ were defined as having a preserved ejection fraction (HFpEF) (Yancy et al., 2013). Numerous studies suggest that a LVEF of $<50 \%$ is associated with the development of heart failure (Fonarow and Hsu, 2016) and a LVEF less than 35\% might be indicative of manifest heart failure.

Besides LVEF, there are several parameters that contribute to the assessment of cardiac function. Left ventricular (LV) geometry and left atrium size is independently associated with morbidity and mortality in patients with HFpEF (Zile et al., 2011). Increased baseline LV mass and abnormal LV geometry portend an increased risk for morbidity and mortality following high-risk myocardial infarction (Verma et al., 2008). 


\subsection{Cellular composition of the heart}

The cell is the basic structural and functional unit of an organ. Proper cell function is essential for maintaining homeostasis. An accurate and up to date knowledge of cardiac cellular composition is needed to better understand normal cardiac function as well as the complex pathogenesis of cardiac disease processes.

A recent study from Pinto et al. (Pinto et al., 2016) analysed cellular composition in adult mouse and human hearts by using a combination of genetic tools and cellular markers. Immunohistochemistry revealed $31.0 \pm 4.2 \%$ of nuclei can be attributed to cardiomyocytes, $43.6 \pm 4.1 \%$ to endothelial cells (ECs), $4.7 \pm 1.5 \%$ to leukocytes and unmarked cells accounted for $20.7 \pm 4.5 \%$ of the nuclei in the adult mouse heart. Afterwards, examination of human tissues demonstrated that $31.2 \pm 5.6 \%$ of nuclei correspond to cardiomyocytes, $53.8 \pm 6.4 \%$ to ECs, and $2.8 \pm 1.2 \%$ to leukocytes. Further detection of non-myocytes in adult mouse hearts delineated a distribution consisting of $64 \%$ ECs, $27 \%$ resident mesenchymal cells (15\% fibroblasts plus $12 \%$ others), and 9\% leukocytes (7\% myeloid plus others). Immunofluorescence detection in murine cardiac tissue further indicated the presence of $5.7 \pm 1.1 \%$ vascular smooth muscle cells (VSMCs) and/or pericytes, which account for a major part of the unmarked cells in the other staining. Current estimation of EC abundance in the human heart reflects those observed in the mouse heart.

Cardiac cellular plasticity has been extensively studied during the last decade. In a study by Bergmann et al. in 2015 (Bergmann et al., 2015), it was determined post-mortem that $73.6 \% \pm 7.0 \%$ of all cardiomyocytes were mono-nucleated, $25.5 \% \pm$ $7.4 \%$ were bi-nucleated, and $1.0 \% \pm 1.2 \%$ were tri-nucleated in the heart of individuals aged one month to 73 years. In agreement with previous studies (Mollova et al., 2013, Olivetti et al., 1996), they established that already 1 month after birth; the final number of cardiomyocytes was reached $\left(3.2 \pm 0.75 \times 10^{9}\right.$ cells $)$ and remained constant throughout life. By stereological measuring the average volume of cardiomyocytes at different ages, it was found that the adaptive about 3 -fold greater 
growth of the left ventricle can be fully explained by the increase in volume of the cardiomyocytes. Moreover, it was shown that cardiac endothelial and mesenchymal cells also expand during physiological growth of the heart.

\subsection{The vascular system}

\subsubsection{Macrovascular and microvascular endothelial cells}

Endothelial cells form a cell monolayer which lines the entire vascular system, from the heart to the smallest capillary. Arteries and veins have a thick wall composed of connective tissue and, at least in arteries, of many layers of smooth muscle cells that constitute the so-called media. The innermost wall, designated intima, is lined by an exceedingly thin monolayer of ECs, known as macrovascular endothelial cells, separated from the surrounding medial layers by a basal lamina. In the finest branches of the vascular tree, the capillaries, the vessel wall consist of nothing but ECs and a basal lamina. These ECs are known as microvascular endothelial cells (Bruce et al., 2002).

\subsubsection{Endothelial cell heterogeneity}

The vascular endothelium is an essential locus of regulatory nodes in the homeostatic network to achieve diverse organ functions (Gimbrone, 1987). In consideration of achieving precise regulation of various functions, heterogeneity among endothelial cells has been extensively investigated.

In general, from a structural point of view, the shape of endothelial cells varies across the vascular tree (Aird, 2007). Thus, endothelial cell thicknesses varies from less than $0.1 \mu \mathrm{m}$ in capillaries and veins to $1 \mu \mathrm{m}$ in the aorta (Florey, 1966). The endothelium of arteries and veins forms a continuous uninterrupted layer of cells, held together by tight junctions. The endothelium of capillaries may be continuous, fenestrated, or discontinuous, according to the needs of the underlying tissue (Aird, 2012). Besides 
such differences at the structural level, ECs show remarkable heterogeneity in function. For example, phosphorylation and movement of adherence junction protein VE-cadherin altered endothelium permeability (Su et al., 2002, Semina et al., 2014). And VE-cadherin was found differently expressed on venous, capillary and arterial endothelial cells (Herwig et al., 2008). Moreover, it was observed (Moldobaeva and Wagner, 2002) that bradykinin caused a maximal increase in permeability in sheep bronchial artery and bronchial microvascular endothelial cells, while thrombin treatment was able to enhance permeability only in microvascular ECs. For studies about endothelial cell function in a particular organ, organ-specific heterogeneity of ECs would be highly interesting.

\subsubsection{Endothelial cell activation and dysfunction}

The term endothelial activation was first coined in the 1960s. Willms-Kretschmer (Willms-Kretschmer et al., 1967) used 'activated' to imply a change of endothelial cell function as well as morphology observed during experiments. Afterwards, numerous studies have shown surface molecule expression change and altered functions in endothelial cells upon cytokine stimulation. In the 1990s, the term endothelial cell activation was reintroduced to emphasize that such changes do not reflect endothelial cell injury or dysfunction (Hunt and Jurd, 1998).

Endothelial dysfunction is a pathological condition characterized mainly by an imbalance between mediators with vasodilating, anti-mitogenic, and anti-thrombotic properties (endothelium-derived relaxing factors) and substances with vasoconstricting, pro-thrombotic, and growth-promoting characteristics (endothelium-derived contracting factors) (Flammer et al., 2012). Furchgott and Zawadzki (Furchgott and Zawadzki, 1980) first described the phenomenon of endothelium-dependent relaxation in 1980. Subsequently, the identification of nitric oxide (NO) as the crucial endothelium-derived mediator of vascular relaxation led to substantial progress in cardiovascular research (Flammer et al., 2012). In addition to 
causing vascular smooth muscle cell (SMC) relaxation, NO is known to selectively reduce endothelial cell expression of adhesion molecules and pro-inflammatory chemokines or cytokines (De Caterina et al., 1995).

Since endothelial cell activation proceeding to endothelial dysfunction was commonly observed, endothelial activation / dysfunction has been studied as two converging concepts. The influence and regulation of endothelial activation / dysfunction has been strongly correlated with the pathogenesis of complex disease processes such as diabetes (Jia et al., 2017, Watt et al., 2017), maladaptive cardiac remodelling (Rose et al., 2017, Tsai et al., 2017), and atherosclerosis (Corban et al., 2017).

\subsubsection{Cardiac endothelium}

The endocardium consists of a continuous endothelial cell monolayer lining the inner wall of the cavities of the heart; therefore they have been termed endocardial endothelial cells and present an organ-specific subtype of macrovascular ECs. The inner surface of the conduit coronary arteries and veins as well as that of the resistance-sized arterioles is covered by a different type of macrovascular ECs while the capillaries and post-capillary venules are lined by a continuous monolayer of microvascular ECs (Noireaud and Andriantsitohaina, 2014). The small coronary arteries and arterioles are able to match blood flow and thus delivery of oxygen and nutrients to the myocardium according to its demand by adapting their tone and thus resistance to blood flow (coronary reserve). This 'auto regulation' may be severely compromised by coronary heart disease, i.e. atherosclerosis in the large conduit arteries preceding the resistance vessels, eventually leading to ischemia of the myocardium. It is the capillaries where oxygen, nutrients and other mediators are exchanged between the blood and the interstitium. Figure 1A shows a cross-section image from an adult mouse myocardium. It clearly delineates that there is at least one capillary next to each cardiomyocyte. This anatomical arrangement of cardiomyocytes within the capillary network not only allows for the exchange of nutrients and 
metabolites but also for a rather intimate bidirectional communication between endothelial cells and cardiomyocytes (Hsieh et al., 2006)

A

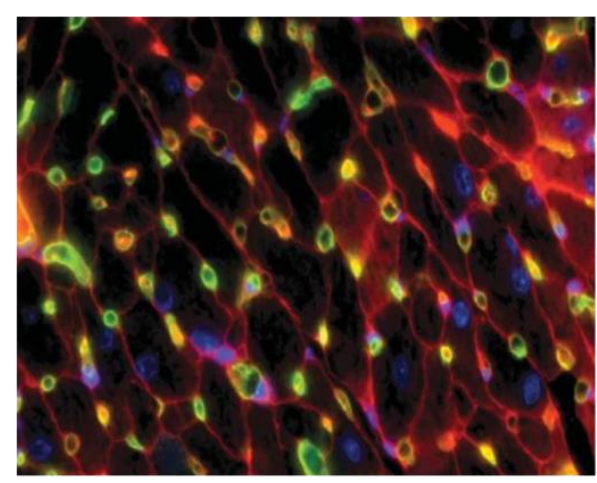

B

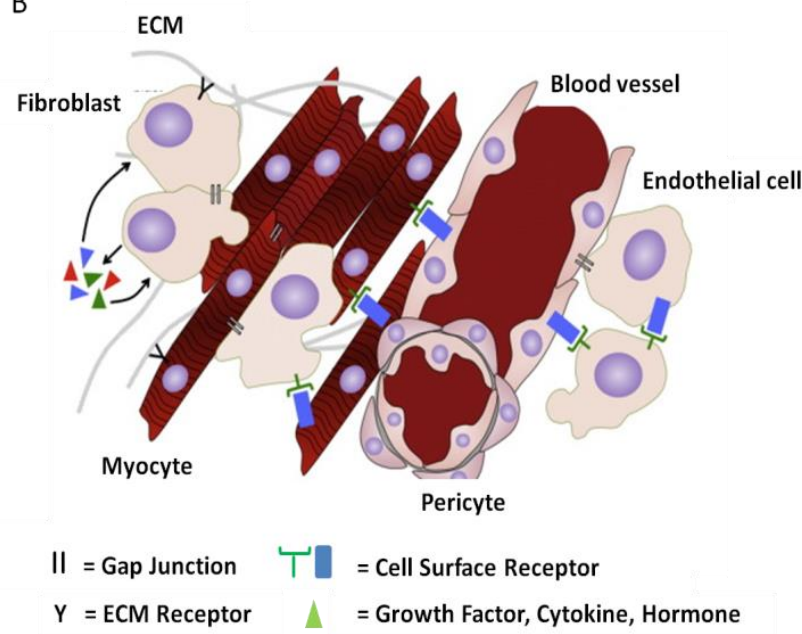

Figure 1. Microvascular endothelial cells in the heart. A. Endothelial cell-cardiomyocyte assembly in an adult mouse myocardium. Cardiomyocyte cell borders are stained in red, capillary EC borders in green (isolectin-fluorescein staining) and nuclei in blue (Hoechst dye). Original magnification: $600 \times$ (Hsieh et al., 2006). B. Endothelial cells interact with cardiac myocytes and fibroblasts though multiple ways (adapted from (Howard and Baudino, 2014)).

As delineated in Figure 1B, it is well-known that capillary ECs interact with nearby cardiomyocytes and fibroblasts thought multiple ways. Cardiomyocytes and endothelial cells communicate through gap junction proteins, such as $\mathrm{Cx} 43$, which link electromechanical processes in the myocardium with the vasculature (Givvimani et al., 2011). The endothelial cell secretory products comprising growth factors, cytokines, NO, endothelin-1, and neuregulin act on myocytes and fibroblasts in a paracrine manner (Takeda and Manabe, 2011, Penna et al., 2017). A recent study showed that NO produced by coronary endothelial cells plays a pivotal role in the cardioprotective effect of exercise (Farah et al., 2017). Moreover, endothelial cell-derived neuregulin protects cardiomyocytes against hypoxia-reoxygenation induced apoptosis and reduces infarct sizes after coronary artery ligation (Hedhli et al., 2011).

The extracellular matrix (ECM) acts as a scaffold for the heart and allows for cellular and acellular networks to form in the heart. It contains molecules released from 
cardiomyocytes and non-myocytes, especially matrix metalloproteinases (MMPs) and tissue inhibitors of metalloproteinases (TIMPs), which correlate with endothelial cell proliferation, increased tube formation, and lead to changes in angiogenesis (Liu et al., 2008, Shen et al., 2016).

\subsection{Cardiac hypertrophy and heart failure}

\subsubsection{A brief macroscopic view of the process of cardiac hypertrophy}

Cardiac hypertrophy is except in endurance sports (Radovits et al., 2013) a maladaptive response of the heart to a variety of extrinsic and intrinsic stimuli. Extrinsic stimuli comprise, e.g. arterial hypertension (Frohlich et al., 1992) or aortic valve stenosis, while familial hypertrophic cardiomyopathy (Marian and Braunwald, 2017) is prototypic for intrinsic stimuli. The critical point during both maladaptive remodelling processes is the biomechanical overload to which the heart is chronically exposed (Frey and Olson, 2003).

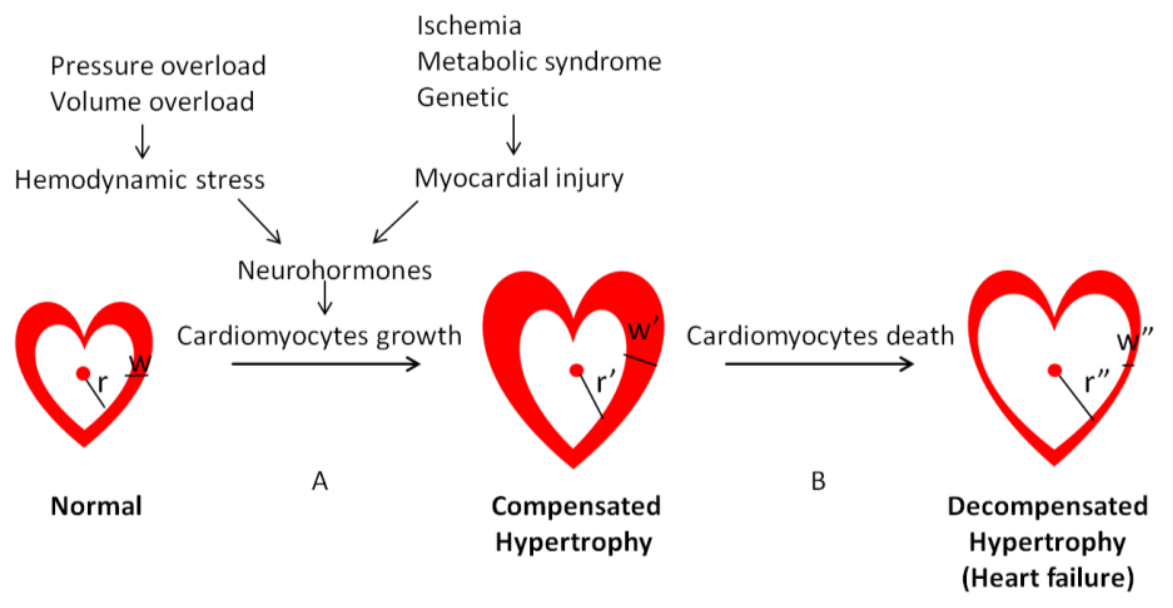

Figure 2. Development and progression of cardiac hypertrophy. A. The progression from a normal heart to 'compensated' hypertrophy, which per se is a maladaptive process (e.g. decreased fractional shortening as the first sign of a systolic dysfunction), manifests itself as cardiomyocyte growth together with an increase in thickness of the (left) ventricular wall ( $w^{\prime}>w$, wall thickness) to normalize wall tension. B. The progression from this intermediate state to decompensated hypertrophy (heart failure) is accompanied by a major remodelling process within the ECM that ultimately causes increased cardiomyocyte apoptosis and necrosis provoking the transition to dilated cardiomyopathy $\left(r^{\prime \prime}>r^{\prime}\right.$, radius of the ventricular cavity) and wall thinning $\left(\mathrm{w}^{\prime \prime}<\mathrm{w}^{\prime}\right)$ hence a major increase in wall tension. Adapted from (Diwan and Dorn, 2007). 
As delineated in Figure 2, in the face of hemodynamic stress or ischemic injury, cardiomyocytes respond with enhanced protein synthesis, heightened organization of the sarcomeres, increased transcriptional activity such as an upregulation of the calcineurin-nuclear factor of activated T-cells (NFAT) pathway, re-expression of fetal genes such as atrial natriuretic peptide (ANP), brain natriuretic peptide (BNP), and $\beta$-myosin heavy chain ( $\beta$-MHC), and manifests itself by increased cardiomyocyte size, ventricular wall thickness and neurohormonal activation. These changes have previously been considered as an adaptive response to maintain cardiac output. In fact, they already lead to systolic dysfunction of the heart because of the compromised slower contraction of the enlarged cardiomyocytes. Moreover, there is an activation of the cardiac fibroblasts which start to remodel the ECM by replacing the normal collagen skeleton with other collagens that are much less tear-resistant. If the inadequate hemodynamic stress persists, the remodelling process ultimately leads to enhanced cardiomyocyte death, increased fibrosis, dilatation of the ventricle and thus a major increase in wall tension that can no longer be compensated (critical heart weight has been reached) so that cardiac output drops below the critical level. In fact, dilated cardiomyopathy, the end-stage of this maladaptive remodelling process, is by far the main reason for affected individuals to develop heart failure (Diwan and Dorn, 2007, Frey and Olson, 2003).

In earlier clinical trials (Hood et al., 1968, Grossman et al., 1975), it was observed that pressure overload of the left heart was exactly counterbalanced by increased wall thickness in the left ventricle. Subsequent studies have shown that this left ventricular hypertrophy is associated with a significantly increased risk of clinical events, such as an enhanced incidence of coronary heart disease as well as increased mortality from cardiovascular disease (Levy et al., 1990, Koren et al., 1991). Some clinical trials further demonstrated that patients with arterial hypertension and echocardiographically documented left ventricular hypertrophy, who received either the $\mathrm{AT}_{1}$ receptor blocker losartan or the $\beta_{1}$ receptor blocker atenolol, were much less likely to experience such a major cardiovascular event (Kjeldsen et al., 2002). Also 
the angiotensin-converting-enzyme inhibitor ramipril significantly reduces the rates of death, myocardial infarction, and stroke in a broad range of high-risk patients (Heart Outcomes Prevention Evaluation Study et al., 2000). It was proposed during the last decade and is meanwhile widely accepted that the development of cardiac hypertrophy should be prevented in patients with pressure overload (Frey et al., 2004). Since then numerous studies have been undertaken to delineate the cellular mechanisms that spur cardiac hypertrophy. With the improved understanding of the process in recent years there has been a controversy about whether inhibition of the development of ventricular hypertrophy is a proper therapeutic strategy in patients with ventricular pressure overload (Schiattarella and Hill, 2015, Crozatier and Ventura-Clapier, 2015).

\subsubsection{Potential circulating biomarkers during cardiac hypertrophy}

\section{- Endothelin-1 (ET-1)}

Endothelin-1 (ET-1) was discovered in 1980 as an endothelial cell-derived peptide with great vasoconstrictive potency. It has been shown that ET-1 achieves its effects through two receptors: the $\mathrm{ET}_{\mathrm{A}}$ receptor, mainly located on vascular smooth muscle cells and on cardiomyocytes; and the $\mathrm{ET}_{\mathrm{B}}$ receptor, mainly located on vascular endothelial cells (Farhat et al., 2008, Sanchez et al., 2002, Brunner et al., 2006). Stimulation by ET-1 has been shown to induce cardiac hypertrophy both in vitro (Jen et al., 2017) and in vivo (Archer et al., 2017). High levels of plasma big endothelin-1, the biological precursor of endothelin-1, were observed to predict a worse prognosis for patients with hypertrophic cardiomyopathy (Wang et al., 2017b). In a recent trial (Demissei et al., 2017) aiming at predicting low risk vs. high risk for early post-discharge death or for readmission to hospital of $\mathrm{HF}$ patients due to acute heart failure, ET-1 plasma levels showed better performance for high-risk prediction than other biomarkers.

\section{- Atrial natriuretic peptide (ANP) and brain natriuretic peptide (BNP)}


Atrial natriuretic peptide (ANP) and brain natriuretic peptide (BNP) are myocardial cell-derived peptides, the release of which is enhanced in response to hypervolemia in the atria or pressure overload in the ventricles, with similar structure but different actions on cardiorenal and fluid homeostasis (Torres-Courchoud and Chen, 2016). ANP is released mainly from the atria in the normal heart, but major amounts were found in ventricles of fetuses and in patients with left ventricular hypertrophy (Federico, 2010). Moreover, the plasma concentration of ANP is elevated in essential hypertension (Kato et al., 1999, Hu et al., 2015), and has been observed to correlated with higher renin activity in some cases, which was further indicated to have a counterregulatory role during activation of the renin-angiotensin-aldosterone system (Sergev et al., 1991). Higher plasma concentration of ANP was also found companioned with more frequent premature ventricular depolarizations, and more advanced hemodynamic abnormalities in patients with chronic heart failure (Gottlieb et al., 1989).

Increased wall tension normally drives synthesis of pre-proBNP in the atrial and ventricular myocardium. Subsequently, the pre-propeptide is cleaved first to proBNP1-108, then to the biologically active BNP1-32 and the inactive amino-terminal fragment (NT-proBNP) (Chen and Burnett, 1999). During cardiac hypertrophy, plasma BNP concentration is a sensitive marker for moderate-to-severe preclinical systolic dysfunction, but less so for milder systolic dysfunction or diastolic dysfunction (Redfield et al., 2004). It was observed that both BNP and NT-proBNP plasma levels are significantly higher in HF patients compared with healthy subjects, whereby NT-proBNP levels are more sensitive and specific to distinguish HF from non-HF subjects (Fonseca et al., 2004). NT-proBNP levels were also suggested to be highly predictive of incident atrial fibrillation, the most common cardiac rhythm abnormality, after adjustment for an extensive number of covariates (Patton et al., 2009).

Although ANP and BNP have been recommended to provide prognostic information 
during the process of cardiovascular diseases, the release of these peptides may considerably influence pathogenesis of the underlying disease processes. Enhanced early endogenous natriuretic peptide activation partly contributes to post-ischemic cardioprotection due to their pro-angiogenic, anti-apoptotic, anti-hypertrophic and anti-fibrotic effects (Lilyanna et al., 2015). ANP also attenuated myocardial fibrosis and inflammation in angiotensin II-induced cardiac remodelling in mice (Fujita et al., 2013). However, there is a study which showed that in mice with dilated cardiomyopathy, cardiac-targeted over-expression of corin, an enzyme that cleaves natriuretic peptides, significantly reduces the development of cardiac fibrosis and enhances cardiac contractile function (Gladysheva et al., 2013). In consideration of the complex disease progresses, the various roles that ANP and BNP play in cardiovascular disease motivate further investigation in this area of research.

\subsection{Cardiac endothelium and cardiac hypertrophy}

\subsubsection{Angiogenesis and cardiac hypertrophy}

During the process of cardiac hypertrophy, along with the growth of cardiomyocytes and enhanced contractility, interstitial cells, such as capillary endothelial cells and cardiac fibroblasts, also dynamically undergo a phenotypic change. While the cardiomyocytes grow in proportion to the increase in heart mass, the capillary network does not expand to the same extent and eventually becomes limiting for oxygen and nutrients supply to the cardiomyocytes when the so-called critical heart weight is reached (Oka et al., 2014). There is evidence that cardiac angiogenesis is enhanced during the acute phase of adaptive cardiac growth (e.g., in endurance athletes) but reduced as hearts undergo pathological remodelling. Enhanced angiogenesis in adaptive remodelling was associated with myocardial VEGF and angiopoietin-2 release, whereas inhibition of VEGF in maladaptive remodelling led to decreased capillary density and impaired cardiac function (Shiojima et al., 2005, Rose et al., 2017). NO production also plays a critical role in the mechanism that couples cardiac angiogenesis to cardiomyocyte growth. Enhancing endothelial cell release of 
NO induced an increase in cardiomyocyte size and left ventricular wall thickness by promoting proteasomal degradation of the regulator of G-protein signalling type 4, RGS-4 (Jaba et al., 2013).

\subsubsection{Endothelial cell - cardiomyocyte interaction during the process of cardiac hypertrophy}

As delineated in Figure 2, endothelial cells communicate with cardiomyocytes and other interstitial cells through multiple channels. E-selectin, intercellular adhesion molecule-1 (ICAM-1) and NADPH oxidase 2 expression in cardiac ECs is upregulated in HFpEF patients as compared to healthy subjects, suggesting that HFpEF is associated with coronary microvascular endothelial cell activation and oxidative stress (Franssen et al., 2016). Cardiac fibrosis is known to contribute largely to the transition of 'compensated' cardiac hypertrophy to heart failure. Endothelial-to-mesenchymal transition contributes to the process of cardiac fibrosis (Zeisberg et al., 2007). Human cardiac endothelial cells abundantly express bone marrow kinase in chromosome $\mathrm{X}(\mathrm{Bmx})$, an arterial non-receptor tyrosine kinase, while very little Bmx is expressed by cardiomyocytes. Angiotensin II (Ang II)-induced cardiac hypertrophy is significantly reduced in mice deficient in Bmx, so that there may be a cross-talk between endothelial cells and cardiomyocytes through Bmx activity during of cardiac remodelling (Holopainen et al., 2015).

\subsection{Aims of the study}

Previous studies have demonstrated an essential role of the cardiac endothelium, namely the vascular ECs, in maintaining proper cardiac function and to prevent pathological remodelling processes underlying cardiac disease. ANP and BNP are crucial peptide mediators released by the myocardium with a variety of functions throughout the cardiovascular system. Despite a multitude of studies on endothelial cell - cardiomyocyte interaction in the heart, very little is known about the influence 
of endothelial cells on ANP and BNP expression by cardiomyocytes.

Myocardial endothelial cell activation influences cardiomyocyte size and contractility, and thus plays an important role in the progression of cardiac hypertrophy. The cellular mechanism underlying this effect has been widely investigated, but has not been uncovered yet. Endothelin-1 is a circulating vasoactive peptide known to induce endothelial cell activation and dysfunction. Plasma ET-1 levels are elevated in patients with arterial hypertension and cardiac hypertrophy. We therefore wondered which effect ET-1 activation of endothelial cells may have on cardiomyocyte ANP and BNP expression in a novel EC-cardiomyocyte interaction model in vitro.

The aims and strategies of this work can be summarized as follows:

1. Basic characterization of the microvascular endothelial cells used in this study.

2. To establish an endothelial cell - cardiomyocyte co-culture system in vitro.

3. To analyse ANP and BNP expression in cardiomyocytes co-cultured with endothelial cells (with and without ET-1 activation).

4. To characterize the nature of this cross-talk between the two cells, whether this requires physical cell-cell contact or is mediated by a humoral EC-derived factor, and to characterize this(these) factor(s) by employing MALDI-TOF mass spectrometry analysis. 


\section{Materials}

\subsection{Consumables}

Tab. 1: Consumables

\begin{tabular}{ll}
\hline Material & Supplier \\
\hline Biosphere ${ }^{\circledR}$ SafeSeal tubes & Sarstedt \\
Cell culture flasks (T-25, T-75) & Sarstedt \\
Cell culture pipettes and tips & Sarstedt \\
Cell culture plates and dishes & Sarstedt \\
Cell scrapers & Sarstedt \\
Falcon ${ }^{\circledR}$ cell culture insert companion plates & Corning \\
Falcon ${ }^{\circledR}$ cell culture inserts $(0.4 \mu \mathrm{m})$ & Corning \\
Glass cover slides & Marienfeld \\
Immobilon ${ }^{\circledR}$-P PVDF membrane $(0.45 \mu \mathrm{m})$ & Merck Millipore \\
Microscope slides & Marienfeld \\
PCR LightCycler ${ }^{\circledR}$ capillaries & Roche \\
Vivaspin ${ }^{\circledR} 6$ centrifugal concentrators & Sartorius \\
\hline
\end{tabular}

\subsection{Cell culture medium and supplements}

Tab. 2: Cell culture medium and supplements

\begin{tabular}{ll}
\hline Material & Supplier \\
\hline Claycomb medium & Sigma-Aldrich \\
DMEM medium & Gibco, Life Technologies \\
$(1 \mathrm{~g} / \mathrm{ml}$ glucose $; 4.5 \mathrm{~g} / \mathrm{ml}$ glucose $)$ & \\
D-PBS & Gibco, Life Technologies \\
ECGS & PromoCell \\
Fetal bovine serum (FCS) for ECs & Gibco, Life Technologies \\
Fetal bovine serum (FCS) for HL-1 cells & Sigma-Aldrich \\
Fungizone & Gibco, Life Technologies \\
\hline
\end{tabular}


Gelatin

HEPES

L-Glutamine

Na-Pyruvate

Non-Essential-Amino-Acids

Norepinephrine

Penicillin/Streptomycin

Trypsin-EDTA
Merck

Sigma-Aldrich

Sigma-Aldrich

Gibco, Life Technologies

Gibco, Life Technologies

Sigma-Aldrich

Gibco, Life Technologies

Gibco, Life Technologies

\subsection{Chemicals and reagents}

Tab. 3: Chemicals and reagents

\begin{tabular}{ll}
\hline Chemical/Reagent & Supplier \\
\hline Acrylamid (30\%) & Merck \\
Agarose & Sigma-Aldrich \\
Angiopoietin-2 (mouse, recombinant) & R\&D system \\
Bovine Serum Albumin & Sigma-Aldrich \\
$\beta$ - Mercaptoethanol & Sigma-Aldrich \\
DCF (CM-H ${ }_{2}$ DCFDA) & Invitrogen \\
DMSO & Sigma-Aldrich \\
Dithiothreitol (DTT) & Sigma-Aldrich \\
Endothelin-1 (human, procine) & Sigma-Aldrich \\
Ethanol (99\%) & Sigma-Aldrich \\
FK506 & Enzo Life Sciences \\
Fluoroshield & Sigma Aldrich \\
Glucose & Mith DAPI \\
IFN-gamma (murine, recombinant) & Gibco, Life Technologies \\
LuminataTM Western HRP Chemiluminescence & Merck Millipore \\
L-Glutamine & Sigmaldrich \\
\hline
\end{tabular}


Naphthylendiamin

Paraformaldehyde (PFA)

Pefabloc

Protein-assay-concentrate

Sodium dodecyl sulfate (SDS)

Sodium chloride

Sulfanilamide

TNF-alpha (murine, recombinant)

TEMED

Tween ${ }^{\circledR} 20$

Triton-X 100
Sigma-Aldrich

Thermo Scientific

Sigma-Aldrich

Bio-Rad

SERVA Electrophoresis

Sigma-Aldrich

Sigma-Aldrich

Gibco, Life Technologies

Carl Roth

Carl Roth

Sigma-Aldrich

\subsection{Buffer solutions}

Tab. 4: Buffer solutions

\begin{tabular}{lll}
\hline Buffer & Composition & \\
\hline Phosphate-buffered saline (PBS) & $\mathrm{NaCl}$ & $8.0 \mathrm{~g}$ \\
(per liter) & $\mathrm{KCl}$ & $0.2 \mathrm{~g}$ \\
& $\mathrm{Na}_{2} \mathrm{HPO}_{4}$ & $1.44 \mathrm{~g}$ \\
& & \\
Tris-buffered saline (TBS) & Tris $(0.5 \mathrm{M})$ & $6.1 \mathrm{~g}$ \\
(per liter) & $\mathrm{NaCl}(1.5 \mathrm{M})$ & $8.75 \mathrm{~g}$ \\
& & \\
PBS-T/TBS-T & $0.5 \mathrm{ml}$ Tween ${ }^{\circledR} 20 \mathrm{in} 1 \mathrm{~L} 1 \times \mathrm{PBS} / \mathrm{TBS}$ \\
& & \\
Homo- I buffer $(2 \times)$ & Tris & $50 \mathrm{mM}$ \\
& KCl & $1.15 \%$ \\
& EDTA & $2 \mathrm{mM}$ \\
& Glucose & $5 \mathrm{mM}$ \\
\hline
\end{tabular}




\begin{tabular}{|c|c|c|}
\hline \multirow[t]{4}{*}{ Homo buffer } & Homo- I buffer $(2 \times)$ & $485 \mu l$ \\
\hline & Dithiothreitol (0.1 M) & $1 \mu l$ \\
\hline & Pefabloc $(40 \mathrm{mg} / \mathrm{ml})$ & $2 \mu l$ \\
\hline & Protease inhibitor mix & $12 \mu 1$ \\
\hline \multirow[t]{4}{*}{ Protease inhibitor mix (PIM) } & Pepstatin A & $1 \mathrm{mg}$ in $200 \mu \mathrm{l} \mathrm{DMSO}$ \\
\hline & Hepes (15 mM) & $800 \mu \mathrm{l}$ \\
\hline & Leupeptin & $1 \mathrm{mg}$ in $200 \mu \mathrm{l} \mathrm{DMSO}$ \\
\hline & Hepes (15 mM) & $800 \mu \mathrm{l}$ \\
\hline Western blot (WB) & Tris & $248 \mathrm{mM}$ \\
\hline \multirow[t]{3}{*}{-Running buffer $(10 \times)$} & Glycine & $1.92 \mathrm{M}$ \\
\hline & SDS & $35 \mathrm{mM}$ \\
\hline & $\mathrm{H}_{2} \mathrm{O}$ & \\
\hline \multirow[t]{3}{*}{ WB-Transfer buffer $(10 \times)$} & Tris & $248 \mathrm{mM}$ \\
\hline & Glycine & $1.92 \mathrm{M}$ \\
\hline & $\mathrm{H}_{2} \mathrm{O}$ & \\
\hline WB-blocking buffer & \multicolumn{2}{|c|}{$5 \%$ Milk powder in TBST } \\
\hline WB-Stripping buffer & $\mathrm{NaOH}$ & $0.2 \mathrm{M}$ \\
\hline
\end{tabular}

\subsection{Kits}

Tab. 5: Kits

\begin{tabular}{ll}
\hline Kit & Supplier \\
\hline RNeasy ${ }^{\circledR}$ RNA extraction Kit & Qiagen \\
Omniscript $^{\circledR}$ Reverse Transcription Kit & Qiagen \\
\hline
\end{tabular}




\begin{tabular}{ll}
\hline QuantiTect $^{\circledR}$ SYBR $^{\circledR}$ Green PCR Kit & Qiagen \\
ANP ELISA Kit & Sigma-Aldrich \\
VEGF-C ELISA Kit & Aviva System Biology \\
\hline
\end{tabular}

\subsection{PCR Primers}

Tab. 6: PCR primers

\begin{tabular}{|c|c|c|c|}
\hline $\begin{array}{l}\text { Gene } \\
\text { (Murine) }\end{array}$ & Sequence & Supplier & $\mathbf{T}_{\text {annealing }}$ \\
\hline \multirow[t]{2}{*}{ ICAM-1 } & For 5'-ATCTCAGGCCGCAAGGG-3' & Biomers & $60^{\circ} \mathrm{C}$ \\
\hline & Rev 5'-CGAAAGTCCGGAGGCTGG-3' & & \\
\hline \multirow[t]{2}{*}{ VCAM-1 } & For 5'-CCCCAAGGATCCAGAGATTCA-3' & Biomers & $60^{\circ} \mathrm{C}$ \\
\hline & Rev 5'-ACTTGACCGTGACCGGCTT-3' & & \\
\hline \multirow[t]{2}{*}{ ANP } & Proprietary & Qiagen & $55^{\circ} \mathrm{C}$ \\
\hline & QuantiTect Primer Assay Mm_LOC230899_1_SG & & \\
\hline \multirow[t]{2}{*}{ BNP } & Proprietary & Qiagen & $55^{\circ} \mathrm{C}$ \\
\hline & QuantiTect Primer Assay Mm_Nppb_1_SG & & \\
\hline \multirow[t]{2}{*}{$\beta-\mathrm{MHC}$} & Proprietary & Qiagen & $55^{\circ} \mathrm{C}$ \\
\hline & QuantiTect Primer Assay Mm_Myh7_1_SG & & \\
\hline \multirow[t]{2}{*}{ RPL32 } & For 5'-GGGAGCAACAAGAAAACCAA-3' & Biomers & $55^{\circ} \mathrm{C}$ \\
\hline & Rev 5'-ATTGTGGACCAGGAACTTGC-3' & & \\
\hline \multirow[t]{2}{*}{ NOS3 } & For 5'-CCTTCCGCTACCAGCCAGA-3' & Biomers & $55^{\circ} \mathrm{C}$ \\
\hline & Rev 5'-CAGAGATCTTCACTGCATTGGCTA-3' & & \\
\hline
\end{tabular}




\begin{tabular}{llll}
\hline MCP-1 & For 5'-CCAGCCGGCAACTGTGA-3' & Biomers & \multirow{2}{*}{$60^{\circ} \mathrm{C}$} \\
& Rev 5'-CCAGCCGGCAACTGTGA-3' & \\
VEGFR2 & For 5'-TAGCTGTCGCTCTGTGGTTCT-3' & Biomers & $58^{\circ} \mathrm{C}$ \\
& Rev 5'-TGTCAGTATGTCTTTCTGTGTGCT-3' & & \\
& & & \\
VEGFR3 & For 5'-AACTCTCCAGCATCCTGACCATC-3' & Biomers & $58^{\circ} \mathrm{C}$ \\
& Rev 5'-AGCCACTCGACACTGATGAAGG-3' & & \\
& & & \\
VEGF-C & Proprietary & Qiagen & $58^{\circ} \mathrm{C}$ \\
& QuantiTect Primer Assay Mm_Vegfc_1_SG & & \\
\hline
\end{tabular}

\subsection{Antibodies}

Tab. 7: Antibodies

\begin{tabular}{lll}
\hline Primary-Antibody & Supplier & Working dilution \\
\hline Mouse monoclonal anti-NOS3 & BD Biosciences & $1: 1000 \mathrm{WB}$ \\
Rabbit monoclonal anti-VACM-1 & Novus Biologicals & $1: 1000 \mathrm{WB}$ \\
Mouse monoclonal anti- $\beta$-actin & Abcam & $1: 5000 \mathrm{WB}$ \\
Mouse monoclonal anti-Ang2 & R\&D System & $1: 1000 \mathrm{WB} ; \quad 1: 400 \mathrm{ICC}$ \\
Rabbit polyclonal anti-vWF & Santa Cruz & $1: 400 \mathrm{ICC}$ \\
& Biotechnology & \\
\hline
\end{tabular}

WB: Western Blot; ICC: Immunocytochemistry

\begin{tabular}{lll}
\hline Secondary-Antibody & Supplier & Working dilution \\
\hline Goat anti Mouse IgG HRP & Rockland Immunochemicals & $1: 5000 \mathrm{WB}$ \\
Goat anti Rabbit IgG HRP & Rockland Immunochemicals & $1: 5000 \mathrm{WB}$ \\
Goat anti rabbit Alexa 488 & LuBioScience & $1: 200 \mathrm{ICC}$ \\
Donkey anti mouse Alexa 568 & LuBioScience & $1: 200 \mathrm{ICC}$ \\
\hline
\end{tabular}

WB: Western Blot; ICC: Immunocytochemistry 


\subsection{Equipment}

Tab. 8: Equipment

\begin{tabular}{ll}
\hline Equipment & Supplier \\
\hline Cell culture CO2 incubator & Nuaire \\
Centrifuge & Eppendorf \\
Cone-and-plate viscometer & Martin-Luther University, \\
& Halle-Wittenberg \\
Dmi1-Light microscope & Leica \\
Fluorescence spectrophotometry & Thermo Fisher Scientific \\
Freezer $\left(-20^{\circ} \mathrm{C}\right)$ & Liebherr \\
Freezer $\left(-80^{\circ} \mathrm{C}\right)$ & Sanyo \\
Fridge $\left(4^{\circ} \mathrm{C}\right)$ & Liebherr \\
ImageQuant ${ }^{\mathrm{TM}}$ LAS 4000 mini Image system & GE Healthcare \\
Laminar airflow workstation & Nuaire \\
LightCycle ${ }^{\circledR} 1.5$ q-RT-PCR system & Roche \\
Mini-Protean ${ }^{\circledR}$ electrophoresis system & Bio-Rad \\
NanoDrop ${ }^{\circledR}$ ND-1000 spectrophotometer & Thermo Fisher Scientific \\
PowerWave & Bio-Tek \\
TCS SP8 confocal microscope & Leica \\
\hline
\end{tabular}




\section{Methods}

\subsection{Cell culture}

\subsubsection{Endothelial cells, cardiomyocytes cell culture}

The mouse cardiac endothelial cell (MCEC) line was prepared from microvascular neonatal mouse cardiac endothelial cells by transfection with lentiviral vectors carrying SV40T antigen and human telomerase. This cell line was provided by Cedarlane $^{\circledR}$, US. Functionally immortalized murine microvascular endothelial cells (CI-muMECs) were provided by InSCREENeX, Germany, with proprietary technology.

MCECs were maintained in DMEM cell culture medium $(1 \mathrm{~g} / \mathrm{ml}$ glucose) with $5 \%$ FCS and $1 \%$ penicillin/streptomycin. CI-muMECs were maintained in DMEM cell culture medium ( $5 \mathrm{~g} / \mathrm{ml}$ glucose) with $20 \%$ FCS, $1 \%$ penicillin/streptomycin, $0.5 \%$ ECGS, $0.02 \%$ Fungizone, $1 \%$ Na-pyruvate and $1 \%$ non-essential-amino-acids. Both cell lines were seeded on $2 \%$ gelatin coated surface, kept at $37{ }^{\circ} \mathrm{C}$, with $5 \% \mathrm{CO}_{2}$ and appropriate humidity.

A cardiac muscle cell line, HL-1, was derived from the AT-1 mouse atrial cardiomyocyte tumor lineage by Claycomb WC et al., and kindly provided. HL-1 cells were seeded on $2 \%$ gelatin/fibronectin coated surfaces. Cells were maintained in Claycomb medium supplied with $10 \%$ FBS, $1 \%$ penicillin/streptomycin, $1 \%$ norepinephrine and $1 \%$ L-glutamine.

Cells were split into sub-cultures at a ratio of 1:3-1:5 at around 90\% confluence, by trypsin-EDTA $(0.05 \%)$ gentle digestion. Cell culture medium was refreshed every 2-3 days.

\subsubsection{Endothelial cells, cardiomyocytes co-culture system}

Two co-culture approaches were used in this study (Figure 3).

Approach 1: HL-1 cells were seeded on the surface of 6-well plates (companion 
plates for Falcon ${ }^{\circledR}$ Transwell inserts), and ECs were seeded on the insert membrane in other 6 well plates without HL-1 cells. The seeding density was adjusted (around 0.5 $\times 10^{6}$ ) so ECs and HL-1 cells reached confluence around same time, then both cells were kept in serum free DMEM medium overnight. Afterwards, Falcon inserts with ECs were moved into companion plates which had HL-1 cells in culture. The ECs were stimulated with/without ET-1 (100nM).

Approach 2: HL-1 cells were seeded on the lower part of the inserts membrane, and kept in a companion plate. ECs were seeded with an appropriate density $\left(0.25 \times 10^{6}\right.$, reach confluence in 3 days) on the top side of inserts membrane two days before HL-1 cells reached confluence (cells on the lower part of the membrane were invisible with ECs seeding on the top). On the third day after seeding ECs (around 100\% confluence), both cell culture media were changed to serum-free DMEM medium. After overnight incubation, ECs were stimulated with or without ET-1 (100 nM).
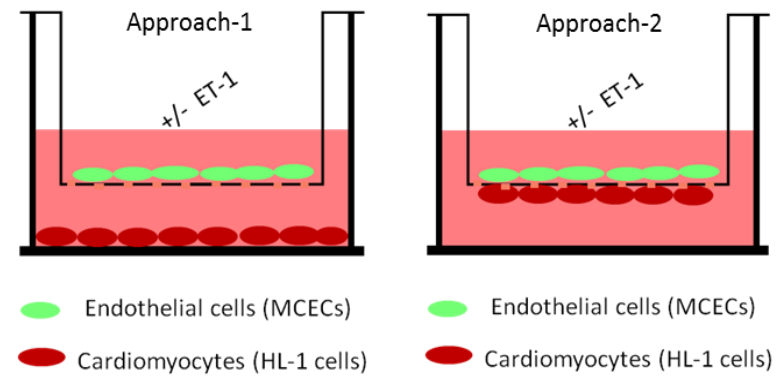

Figure 3. Endothelial cell-cardiomyocyte co-culture system in vitro. Two different approaches of the co-culture system were used. Endothelial cells seeded on the insert membrane with cardiomyocytes seeded on the surface of the companion plate (Approach 1) or on the other side of the membrane (Approach 2).

\subsubsection{Preparation of endothelial cell conditioned medium}

After reaching confluence, ECs were gently rinsed with serum-free DMEM medium twice and kept in serum-free DMEM medium for overnight incubation. ECs were stimulated with or without ET-1 the next morning. After 24 hours, cell culture supernatant was collected and centrifuged at $1000 \mathrm{rpm}$ for $5 \mathrm{~min}$ at $4^{\circ} \mathrm{C}$. The supernatant was kept at $-80^{\circ} \mathrm{C}$ as $500-\mu 1$ aliquots (endothelial cell conditioned 
medium, ECCM) after being flash frozen in liquid nitrogen.

To test the effect of ECCM on fetal gene expression in HL-1 cells, ECCM aliquots were thawed at $37^{\circ} \mathrm{C}$ and added to HL-1 cells as half volume of the total cell culture supernatant (Figure 4A). To test the effect of different fractions of ECCM, separated by molecular weight, EC culture supernatant was centrifuged at $1000 \mathrm{rpm}$ for $5 \mathrm{~min}$, then further centrifuged with Vivaspin ${ }^{\circledR}$ centrifugal concentrators with different membrane sizes $(10,30,50,100 \mathrm{kDa})$ at a ratio of 5 to 1 (Figure $4 \mathrm{~B}$ ). To prepare samples for mass spectrometry (MS) analysis, cell culture supernatant was concentrated with Vivaspin ${ }^{\circledR}$ centrifugal concentrator of $10 \mathrm{kDa}$ membrane size, at a ratio of about 25 to 1 . The final protein concentration must be higher than $0.5 \mu \mathrm{g} / \mu \mathrm{l}$ (the lowest detection rang for MS) in successfully prepared samples, selected by Bradford protein concentration measurement.

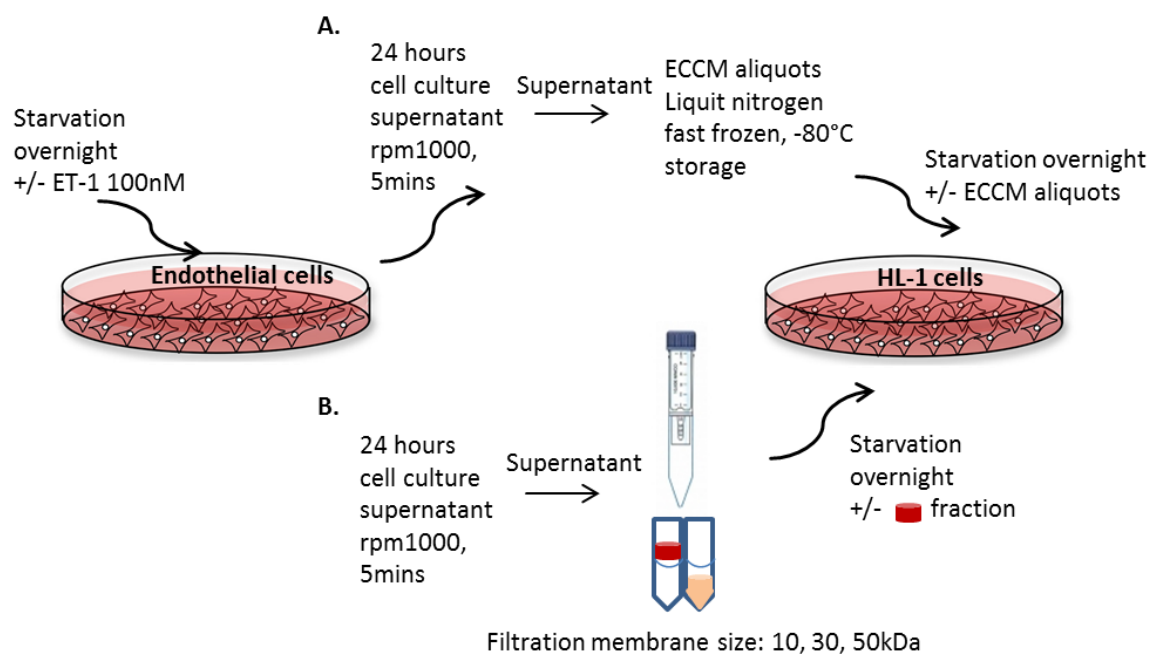

Figure 4. Preparation and experimental procedures of EC-conditioned medium (ECCM). A. Experimental procedure of EC-conditioned medium (with/without ET-1 pre-incubation) and its application on HL-1 cells. B. Experimental procedure of EC-conditioned medium fractions with centrifugal concentrators and its application on HL-1 cells.

\subsubsection{Fluid shear stress in vitro}

CI-muMECs were seeded on $60 \mathrm{~mm}$ cell culture dishes. Upon reaching confluence, $3 \%$ vinyl pyrrolidone was added to cell culture medium to increase its viscosity, and cells were subjected to unidirectional shear stress $\left(\approx 30 \mathrm{dyn} / \mathrm{cm}^{2}\right)$ in a cone-and-plate 
viscometer at $37^{\circ} \mathrm{C}$ with $5 \% \mathrm{CO}_{2}$. After 24 hours, cell culture supernatant and the cell pellet was collected separately and kept at $-80^{\circ} \mathrm{C}$. This part was done in collaboration with Dr. Cordula Rumig.

\subsection{Biochemistry methods}

\subsection{1 mRNA expression analysis}

\subsubsection{1 mRNA extraction from cultured cells}

Adherent cells were rinsed with ice-cold D-PBS twice and $350 \mu \mathrm{l}$ of RNeasy ${ }^{\circledR}$ lysis buffer containing $1 \% \beta$-mercaptoethanol was added into each cell culture well. After gently shaking the whole plate for 1-2 minutes, same volume of $70 \%$ ethanol (350 $\mu \mathrm{l})$ was added into each well. The mixture from each sample was transported into an mRNA extraction column (from RNeasy ${ }^{\circledR}$ RNA extraction Kit), and extraction was performed according to the manufacturer's instructions. At the last step, total RNA was eluted from each column with 20-30 $\mu 1$ RNase-free water. The concentration and extraction quality of RNA was measured with a NanoDrop ${ }^{\circledR}$ ND-1000 spectrophotometer.

\subsubsection{Reverse Transcription (RT)}

Reverse Transcription was performed with the Omniscript ${ }^{\circledR}$ RT kit. According to the measured concentration, 1,000 ng RNA from each sample was diluted with RNase-free water to a volume of $12 \mu \mathrm{l}$ in a Biosphere ${ }^{\circledR}$ SafeSeal Tube $(1.5 \mathrm{ml})$, and then $8 \mu \mathrm{l}$ of Master Mix was prepared and added into the tube according to the manufacturer's instructions. The mixture was incubated at $37^{\circ} \mathrm{C}$ for $60 \mathrm{~min}$ and diluted with $80 \mu \mathrm{l}$ of water. The final concentration of cDNA in each tube was 10 $\mathrm{ng} / \mu \mathrm{l}$.

\subsubsection{Quantitative real time polymerase chain reaction (qRT-PCR)}

Quantitative real time PCR was performed with a LightCycler ${ }^{\circledR}$ instrument and the 
QuantiTect $^{\circledR}$ SYBR $^{\circledR}$ Green Kit. Briefly, $5 \mu$ cDNA (10 ng/ $\mu$ l) was mixed with $10 \mu \mathrm{l}$ QuantiTect buffer, $1 \mu \mathrm{l}$ forward primer $(0.5 \mu \mathrm{M}), 1 \mu \mathrm{l}$ reverse primer $(0.5 \mu \mathrm{M})$, and 3 $\mu 1$ water to a total volume of $20 \mu 1$ in one LightCycler ${ }^{\circledR}$ capillary. Polymerase chain reaction was performed according to the program listed in Table 9. To analyse the gene expression differences among samples in each experiment, the target gene expression was expressed relative to a stably expressed reference gene within the same samples. In this study, mouse 60S ribosomal protein L32 (mRPL32) was used as a reference gene. The relative target gene expression $(\mathrm{R})$ was calculated according to Equation 1 (Michael W. Pfaffl, 2001).

$$
\mathrm{R}=\frac{\left(\mathrm{E}_{\text {target }}\right)^{\Delta \mathrm{CP} \text { target }} \text { (contrl-sample) }}{\left(\mathrm{E}_{\mathrm{ref}}\right)^{\Delta \mathrm{CP} \text { ref }} \text { (contrl-sample) }}
$$

The corresponding real-time PCR efficiency (E) was calculated from the given slope in the LightCycler software as Equation 2.

$$
\mathrm{E}=10^{[-1 / \text { slope }]}
$$

The crossing point $(\mathrm{CP})$ is defined as the point at which the fluorescence rises appreciably above the background fluorescence.

\begin{tabular}{|c|c|c|c|}
\hline Program & Temperature & Time & Number of cycles \\
\hline Denaturation & $95^{\circ} \mathrm{C}$ & 15 minutes & 1 \\
\hline \multirow[t]{3}{*}{ Quantification } & $94^{\circ} \mathrm{C}$ & 15 seconds & \multirow{3}{*}{$40-45$} \\
\hline & $\mathrm{T}_{\text {annealing }}$ & 30 seconds & \\
\hline & $72^{\circ} \mathrm{C}$ & 30 seconds & \\
\hline \multirow[t]{3}{*}{ Melting } & $95^{\circ} \mathrm{C}$ & 15 seconds & \multirow[t]{3}{*}{1} \\
\hline & $65^{\circ} \mathrm{C}$ & 30 seconds & \\
\hline & $95^{\circ} \mathrm{C}$ & 30 seconds & \\
\hline Cooling & $40^{\circ} \mathrm{C}$ & 10 minutes & 1 \\
\hline
\end{tabular}

Tab. 9: Quantitative real time polymerase chain reaction program 


\subsubsection{Protein expression analysis}

\subsubsection{Total cellular protein extraction}

Cells were rinsed twice with ice-cold D-PBS and scraped off into $1 \mathrm{ml}$ of ice-cold D-PBS. Cell suspension from each sample was collected in a $1.5 \mathrm{ml}$ Eppendorf ${ }^{\circledR}$ tube and centrifuged at 3,000 rpm for $3 \mathrm{~min}$ at $4{ }^{\circ} \mathrm{C}$. The cell pellets were re-suspended in $50 \mu \mathrm{l}$ Millipore ${ }^{\circledR}$ water after removing the supernatant. Cell suspensions were flash frozen in liquid nitrogen and immediately thereafter thawed at $37^{\circ} \mathrm{C}$ for 5 cycles to break up the cell membranes and release the cellular protein. Same amount of homo-1 buffer was added into each tube and the mixture was centrifuged at 3,000 rpm for 5 min at $4{ }^{\circ} \mathrm{C}$. The supernatants were collected and transferred into fresh tubes and the protein samples were then flash frozen in liquid nitrogen and stored at $-80^{\circ} \mathrm{C}$.

\subsubsection{Protein concentration measurement}

Protein concentration was measured using the Bradford method. Briefly, sample dilutions were prepared at 1:50 or 1:100 ratios (4 $\mu 1$ sample in $196 \mu 1$ water or $2 \mu 1$ sample in $198 \mu \mathrm{l}$ water). Two hundred $\mu \mathrm{l}$ Bio- $\operatorname{Rad}^{\circledR}$ Bradford Reagent was added into each well of a 96-well ELISA plate, $80 \mu \mathrm{l}$ water (blank), $80 \mu \mathrm{l}$ standard protein $(5,10$, $15,20,30 \mu \mathrm{g} / \mathrm{ml})$ and $80 \mu 1$ sample dilutions were added into each well in duplicates. The absorbance of each well was measured at $595 \mathrm{~nm}$ with a Powerwave ${ }^{\circledR}$ spectrophotometer and the concentration of the protein sample calculated by using the standard curve.

\subsubsection{Sodium dodecylsulfate polyacrylamide gel electrophoresis (SDS-PAGE)}

SDS-PAGE was preformed to separate proteins generally by molecular weight. A $10 \%$ separating gel and 4\% stacking gel was prepared according to the protocol below (Table 10). Equal amount of protein (5 to $15 \mu \mathrm{g}$ ) from each sample was diluted with water to a volume of $18 \mu 1$ and then mixed with $6 \mu$ of $4 \times$ loading buffer. The mixture was heated at $95^{\circ} \mathrm{C}$ for $5 \mathrm{~min}$ and loaded into each pocket in the gel. Proteins were 
separated by electrophoresis in running buffer at $80 \mathrm{~V}$ in the stacking gel for around $30 \mathrm{~min}$ and then at $110 \mathrm{~V}$ in the separating gel for around 1.5 hours. A dual colour protein standard marker was loaded onto each gel to estimate the electrophoresis process and general distribution of the proteins.

Tab. 10: SDS-PAGE gel preparation

\begin{tabular}{lll}
\hline & $\begin{array}{l}\text { Separating gel } \\
\text { 1 gel }(\mathbf{5} \mathbf{~ m l})\end{array}$ & Stacking gel \\
& 1.2 & $\mathbf{1}$ gel $(\mathbf{1 . 5} \mathbf{~ m l})$ \\
\hline $\mathrm{H}_{2} \mathrm{O}(\mathrm{ml})$ & 2 & 1.1 \\
Tris- $\mathrm{HCl} \mathrm{pH}=8.8(\mathrm{ml})$ & 1.7 & 0.188 \\
$30 \%$ Acrylamide $(\mathrm{ml})$ & 50 & 0.2 \\
$10 \%$ SDS $(\mu \mathrm{l})$ & 50 & 15 \\
$10 \%$ APS $(\mu \mathrm{l})$ & 3 & 15 \\
TEMED $(\mu \mathrm{l})$ & & 1.5 \\
\hline
\end{tabular}

\subsubsection{Western blotting}

After electrophoresis separation, proteins in the gel were transferred onto a methanol activated PVDF membrane in transfer buffer at $350 \mathrm{~mA}$ for $60-90$ min (mainly dependent on the target protein size). Then the membrane was rinsed in 5\% non-fat dried Blotto ${ }^{\circledR}$ milk dissolved in TBS-T for 30-60 min to block unspecific binding. After blocking, the membrane was incubated with first antibody, dissolved in TBS-T at a ratio of $1: 500$ to $1: 2000$, overnight at $4^{\circ} \mathrm{C}$. Subsequently, the membrane was rinsed in TBS-T 3 times, 5 min each, and incubated with species specific secondary antibody for 60-90 min at RT. Afterwards; the membrane was rinsed twice in TBS-T, once in TBS and then developed with Luminata ${ }^{\circledR}$ Forte substrate according to the manufacturer's instructions. Finally, the visualized bands were analysed using Image J software (NIH, Bethesda, Maryland, USA). Similar to mRNA expression analysis, $\beta$-actin was used as a reference gene in each experiment. 


\subsubsection{Enzyme Linked Immunosorbent Assay (ELISA)}

The concentration of ANP released by HL-1 cells and VEGF-C released by ECs in cell culture supernatants were measured by ELISA. There are four most commonly used ELISA types (Figure 5A). In this study, the mouse-VEGF-C ELISA kit is based on the standard sandwich ELISA technology. The working procedure is briefly shown in Figure 5B. The ANP ELISA kit is an assay based on the principle of competitive enzyme immunoassay, as shown in Figure 5C.

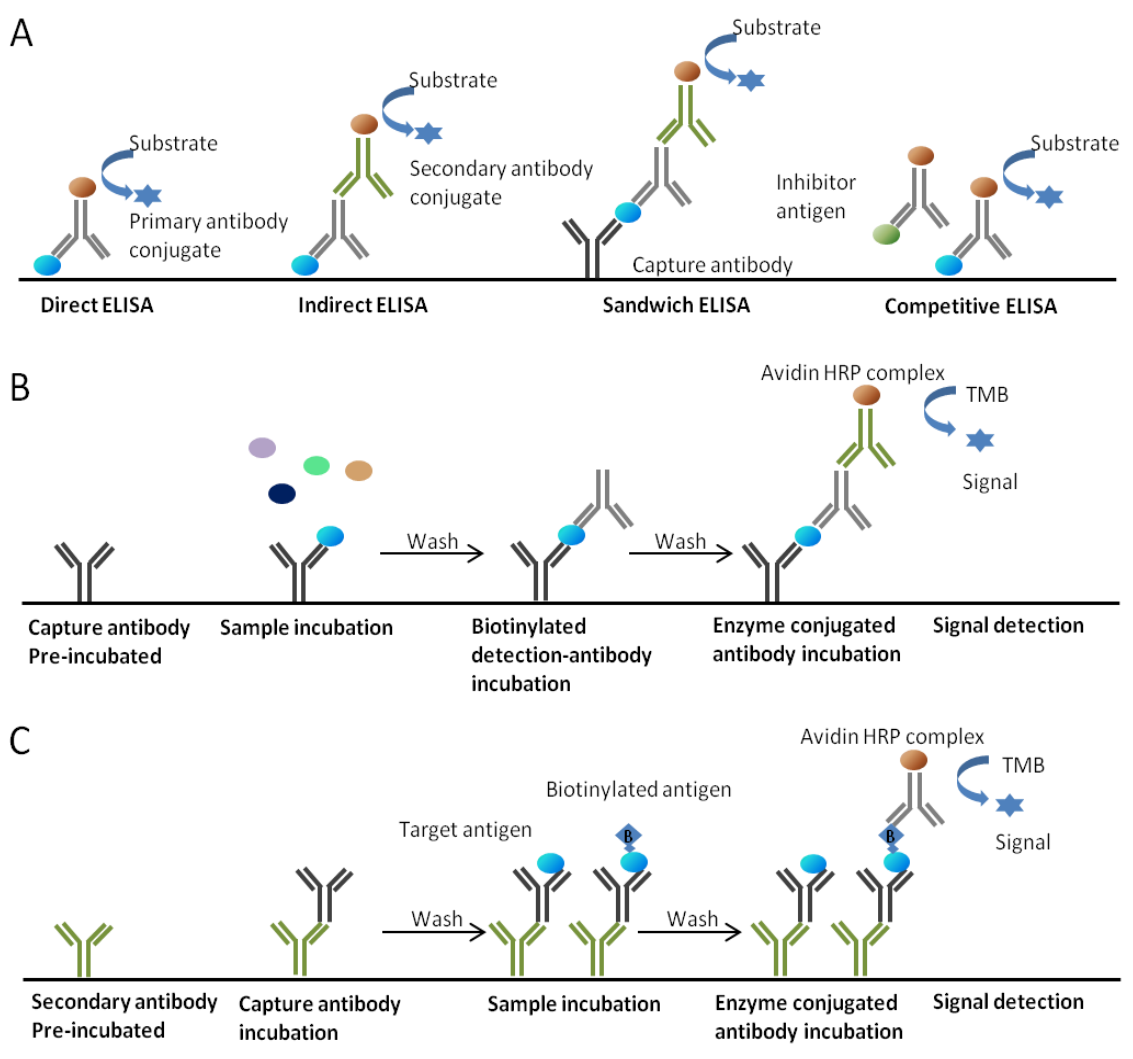

Figure 5. Principle of ELISA kits used. A. Four commonly used ELISA types. B. Working procedure of the VEGF-C Standard Sandwich ELISA kit. A 96-well plate had been pre-coated with VEGF-C specific antibody. Test samples were added into the wells, incubated and removed. A biotinylated detection antibody specific for VEGF-C was added, incubated and followed by washing. Avidin-Peroxidase Conjugate was added, incubated and unbound conjugate was washed away. An enzymatic reaction was produced through the addition of TMB substrate which is converted by HRP, generating a blue: colour product that changed to yellow after adding acidic stop solution. The absorbance of the yellow colour read at $450 \mathrm{~nm}$ is quantitatively proportional to the amount of VEGF-C captured in the wells. C. Working procedure of the ANP competitive ELISA kit. The microplate was pre-coated with secondary antibody. After incubation with anti-ANP capture antibody, both target ANP peptide in samples and biotinylated ANP peptide $(10 \mathrm{pg} / \mathrm{ml})$ competitively interacted with the capture 
antibody. Bound biotinylated ANP peptide interacted with HRP, causing the same colour development as described above, the intensity of which is quantitatively proportional to the amount of biotinylated ANP peptide-HRP complex and inversely proportional to the amount of ANP peptide in tested samples. (Adapted from the manufacturer's instructions: Sigma-Aldrich, USA; Aviva System Biology, USA)

\subsubsection{Mass spectrometry (MS) analysis}

Preparation of ECCM samples for MS analysis was briefly introduced in Figure 4B. For each sample, ECCM was collected from one T25 flask, and centrifuged with a $10-\mathrm{kDa}$ centrifugal concentrator to a ratio of about 25:1. For comparison of ECCM contents with or without ET-1 stimulation, each pair of samples was prepared from two flasks of ECs with the same sub-culture passage and seeding density.

After digestion by using trypsin as a protease, the tryptic peptides were cleaned up using C18 pipette tips from Merck KGaA (Damstadt, Germany). The peptide solution was dried under vacuum and resuspended using water containing 3\% acetonitrile $(\mathrm{MeCN})$ and $0.1 \%$ formic acid (FA).

High-performance liquid chromatography experiments were performed using the UltiMate3000 system (Dionex) and a Kinetex C18 column (Phenomenex, 2-6 $\mu \mathrm{m}$, $100 \AA$, i.d. $2.1 \mathrm{~mm}$ and length $100 \mathrm{~mm}$ ). Water containing $5 \% \mathrm{MeCN}$ and $0.1 \% \mathrm{FA}$ was used as solvent $\mathrm{A}$ and $\mathrm{MeCN}$ containing $5 \%$ water and $0.1 \% \mathrm{FA}$ as solvent $\mathrm{B}$. A flow rate of $0.25 \mathrm{~mL} / \mathrm{min}$ was used for each run. A multi-step gradient approach was used for peptide separation starting with $2 \%$ B. In 7-9 min, B was increased from $2 \%$ to $40 \%$. Afterwards, B was increased to $50 \%$ in $5 \mathrm{~min}$, further increased to $98 \%$ in 3 min and kept at $98 \%$ for 8 min. The gradient was then ramped down to $2 \% \mathrm{~B}$ in $3 \mathrm{~min}$. The HPLC system was coupled to a Q-Exactive Orbitrap mass spectrometer (Thermo Fisher Scientific GmbH, Bremen, Germany) using a mass range of $m / z$ 350-1,800 and a mass resolution of 140,000 for full MS. The top ten peaks were fragmented using higher energy collisional dissociation (HCD) and a dynamic exclusion of $15 \mathrm{~s}$. The data were analysed using Proteome Discoverer, Version 1.4. This part was done by Pegah Khamehgir-Silz, Justus-Liebig University, Giessen, Germany. 


\subsubsection{Cellular reactive oxygen species detection assay}

Endothelin-1 (ET-1) induced cellular reactive oxygen species in ECs were detected by DCF-DA. Cells seeded in 12-well plates were rinsed with warm D-PBS twice after reaching confluence, and incubated in D-PBS containing $5 \mu \mathrm{M} \mathrm{DCF}$ and $1 \mathrm{~g} / 1$ glucose at $37^{\circ} \mathrm{C}$ for $60 \mathrm{~min}$. ET-1 $(1,10,100 \mathrm{nM})$ was added to the ECs, and fluorescence was measured at $485 \mathrm{~nm}$ excitation/538 nm emission using a fluorescence spectrometer, at the time points $1 \mathrm{~min}$ before, and 30, 60 and $120 \mathrm{~min}$ after adding ET-1.

\subsubsection{Extracellular nitric oxide (NO) detection assay}

Extracellular NO levels in ECs with or without fluid shear stress or ET-1 stimulation was detected indirectly by measuring nitrite $\left(\mathrm{NO}_{2}^{-}\right)$using the Griess reaction assay. Solution A (1\% (w/v) Sulfanilamide dissolved in 1 N HCL) and solution B $(0.1 \%$ (w/v) N-1-napthylethylenediamine dihydrochloride, NED dissolved in $1 \mathrm{~N} \mathrm{HCL}$ ) were prepared and stored at $4{ }^{\circ} \mathrm{C}$ protected from light. Nitrite standards were freshly prepared with dilutions of $100 \mu \mathrm{M} \mathrm{NaOH}$. Both solutions were equilibrated to ambient temperature (15-30 min) at the beginning of each experiment. Fifty $\mu$ l of each sample and standards were added into 96-well plates in duplicate, followed by adding $50 \mu 1$ solution A and 10 min incubation (RT, protected from light). Afterwards, $50 \mu 1 \mathrm{~B}$ was added into each well and incubated for $10 \mathrm{~min}$ (RT, protected from light). Absorbance at 520-550 nm was measured using a microplate reader within $30 \mathrm{~min}$ and nitrite concentration was calculated according to the standard curve.

\subsection{Immunocytochemistry}

\subsubsection{Cell fixation}

Cells cultured on circular glass cover slips were rinsed with PBS and fixed in 4\% PFA for 20 min. PFA was removed and cells were rinsed twice again with PBS. Thereafter, they were either processed for immunofluorescence staining or kept at $4^{\circ} \mathrm{C}$. 


\subsubsection{Immunofluorescence staining}

PBS supplied with $1 \%$ BSA plus $0.3 \%$ TritonX served as a blocking buffer and antibody solvent. Cells were kept in blocking buffer for 30 min to reduce unspecific binding. Afterwards, they were incubated with primary antibody solution for 2 hours, followed by $3 \times 5$ min washing with PBS. Cells were kept in species specific secondary antibody solution for 1 hour and then washed 3 times with PBS for 5 min. These washes were performed at ambient temperature with 1-2 $\mathrm{rpm} / \mathrm{sec}$ gentle shaking. Finally, glass cover slips were rinsed quickly with Millipore water, and put on one drop of Fluoroshield ${ }^{\mathrm{TM}}$ DAPI (cells face down) on clean microscope slides. Slides were kept in light-protected box at $4^{\circ} \mathrm{C}$.

\subsubsection{Microscopy}

Confocal microscopy (Leica TCS SP8 laser scanning) was used to detect fluorescence from prepared slides (this part was done with Dr. Nina D. Ullrich and Dr. Sarawuth Wantha, Cardiovascular Physiology, Heidelberg University). Fluorescence density was calculated and analysed by the Leica Application Suite (Leica Microsystems, Mannheim, Germany) and Image J software (NIH, Bethesda, Maryland, USA).

\subsection{Statistical analysis}

All data are presented as means \pm standard error of the mean (SEM). Comparison among samples from multiple groups was performed by using one-way ANOVA followed by a suitable post-hoc test. Unpaired student's $t$-test was applied for comparisons between two groups. For comparison of two groups in which the values in one group were reference values such as 1 or $100 \%$, a one-sample $t$-test was performed. All statistical calculations were performed by using the InStat3 software package (GraphPad, San Diego, California, USA). A probability of $<0.05$ was considered to be significantly different. Probability values are presented as $* \mathrm{p}<0.05$, $* * \mathrm{p}<0.01$, and $* * * \mathrm{p}<0.001$. Box plot figures present data distribution as median 
line and range within 1.5 IQR (interquartile range, 25\%-75\%), and these were analysed by using OriginLab (Northampton, Massachusetts, USA). 


\section{Results}

\subsection{Characterization of endothelial cells}

\subsubsection{Characterization of CI-muMECs}

The CI-muMECs cell line is pulmonary and immortalized with proprietary technology. Experiments using immortalized human umbilical vein endothelial cells (iHUVECs) produced with the same technology showed satisfying performance in one study from our lab (Heiss et al., 2015). There was no available reference of experiments with CI-muMECs. In this context, basic characterization of CI-muMECs with cytokine stimulation was performed at the beginning of this study.

CI-muMECs were seeded in 12-well plates and stimulated with cytokines (TNF $\alpha$ $100 \mathrm{U} / \mathrm{ml}+\mathrm{IFN} \gamma 1,000 \mathrm{U} / \mathrm{ml}$ ) after reaching confluence. Cells were stimulated and harvested after 4, 8, 16 and 24 hours in the first trial. qRT-PCR analysis delineated peaks of VCAM-1 and MCP-1 expression around 8 hours (Figure 6A). EC-marker genes expression was therefore checked at 8 hours in the following experiments. As shown in Figure 6B, after cytokine stimulation, NOS3 mRNA expression slightly decreased; VCAM-1, ICAM-1 and MCP-1 mRNA expression increased significantly.

A

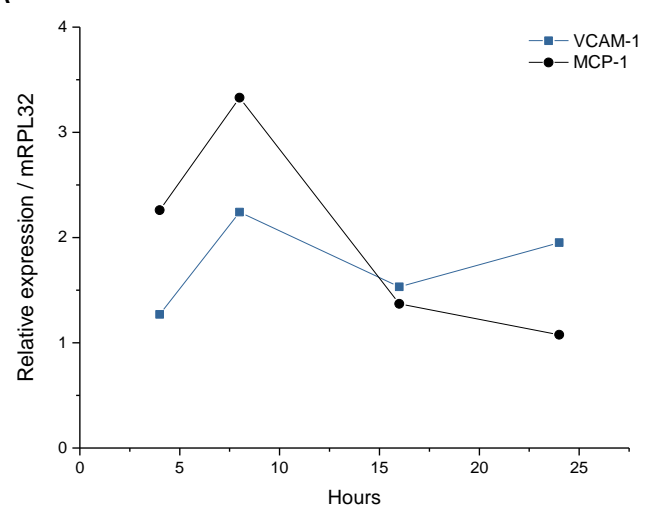

B

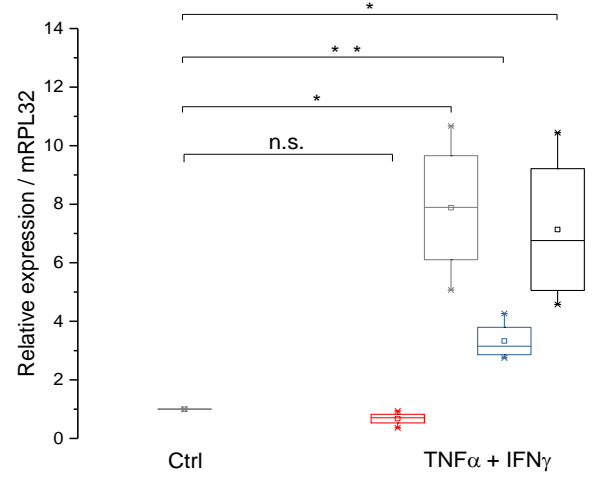

Figure 6. EC-marker gene expression in CI-muMECs after cytokine stimulation on the mRNA level. A. VCAM-1 and MCP-1 mRNA expression in CI-muMECs after 4, 8, 16 and 24 hours with cytokine (TNF $100 \mathrm{U} / \mathrm{ml}+\mathrm{IFN} \gamma 1,000 \mathrm{U} / \mathrm{ml})$ stimulation, exemplary experiment. B. NOS3 (red), VCAM-1 (grey), ICAM-1 (blue) and MCP-1 (black) mRNA expression in CI-muMECs at 8 hours after stimulation with the same cytokines, $n=4$. The respective mRNA level in non-stimulated cells was set to $1 .{ }^{*} \mathrm{p}<0.05,{ }^{*} \mathrm{p}<0.01$ as indicated; n.s., not significant. 
As shown in Figure 7A, in agreement with the mRNA expression data, VCAM-1 protein abundance was significantly upregulated after cytokine stimulation. To subsequently detect NO production in CI-muMECs exposed to unidirectional fluid shear stress $\left(\mathrm{FSS}, \approx 30 \mathrm{dyn} / \mathrm{cm}^{2}\right.$ ), NOS3 protein expression was analysed by Western blot and formation of $\mathrm{NO}$ was detected indirectly by using the Griess reaction. As shown in Figure 7B, there was an increase in cellular NOS3 protein abundance with FSS, and the nitrite concentration in the supernatant (Figure 7C) was also significantly upregulated.

A

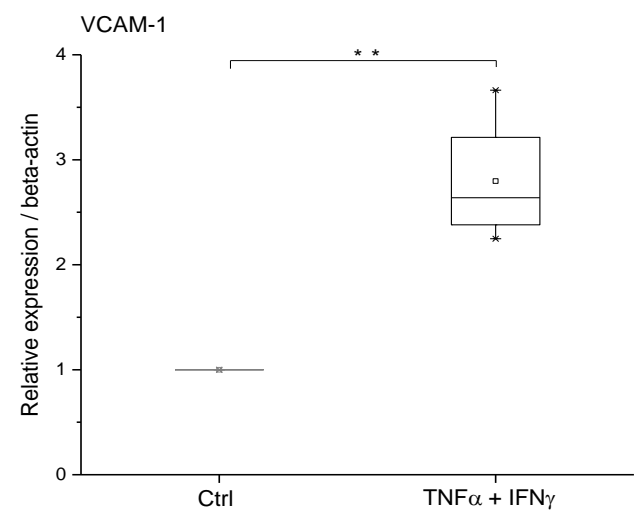

C

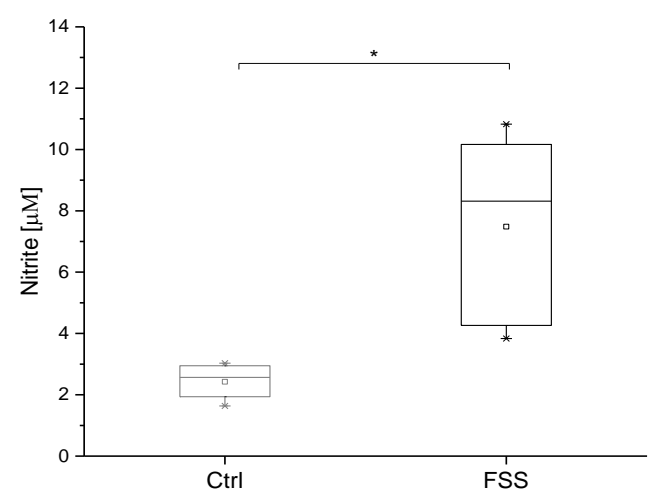

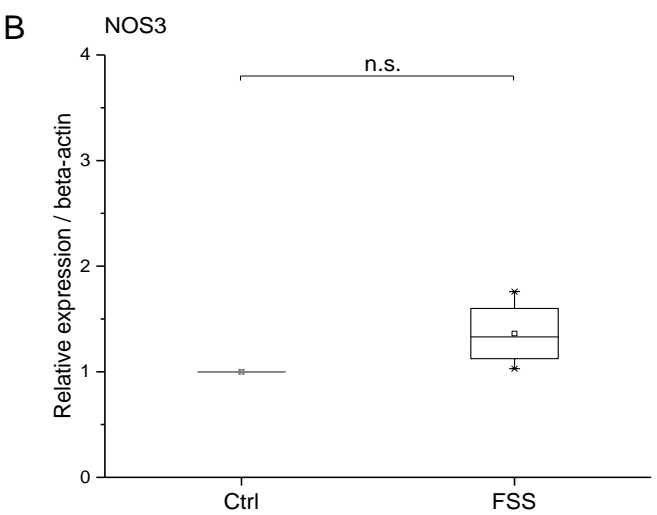
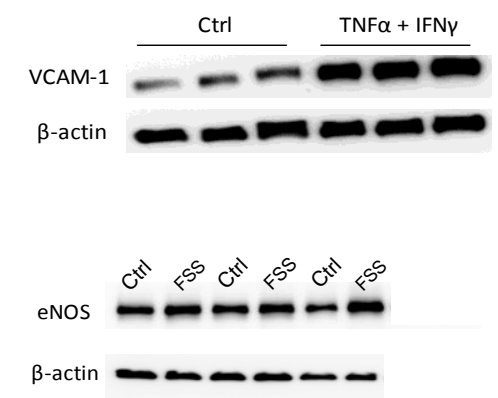

Figure 7. VCAM-1 protein (A), NOS3 protein (B) expression and NO production $(C)$ in CI-muMECs. Ctrl: CI-muMECs without stimulation; TNFa + IFN $\gamma$ : CI-muMECs stimulated with TNF $\alpha 100 \mathrm{U} / \mathrm{ml}+$ IFN $\gamma$ 1,000 U/ml for 24 hours; FSS: CI-muMECs exposed to unidirectional fluid shear stress $\left(30 \mathrm{dyn} / \mathrm{cm}^{2}\right)$ for 24 hours. VCAM-1 and eNOS protein expression: $n=4$; nitrite production: $n=5$. Inserts below $\mathrm{A}$ and $\mathrm{B}$ show original Western blots. $* \mathrm{p}<0.05, * * \mathrm{p}<0.01 ;$ n.s., not significant. 


\subsubsection{Characterization of MCECs}

The MCEC cell line has been widely used in previous researches (Barbieri and Weksler, 2007, He et al., 2008, Barbieri et al., 2008). Therefore, not much characterization experiment with cytokine stimulation was performed.

\subsubsection{ROS production in MCECs}

There have been numerous reports about endothelin-1 (ET-1) and oxidative stress in the cardiovascular system (Xu et al., 2004, Leurgans et al., 2016). Since ET-1 was a crucial molecule in our study, the effect of ET-1 on ROS production in MCECs was investigated. ROS production in MCECs was detected with DCF-DA. As detailed in the methods section, fluorescence at $485 / 538 \mathrm{~nm}$ was measured at $1 \mathrm{~min}$ before and 10, 30, 60, $120 \mathrm{~min}$ after ET-1 (1, 10, $100 \mathrm{nM})$ stimulation. Cells with ET-1 stimulation showed no $(1 \mathrm{nM})$, rather modest $(10 \mathrm{nM})$ and significant $(100 \mathrm{nM})$ increase in fluorescence as compared to the non-stimulated control cells with time (Figure 8). The maximum detection period was $120 \mathrm{~min}$ in these experiments due to the occurrence of cell detachment thereafter.

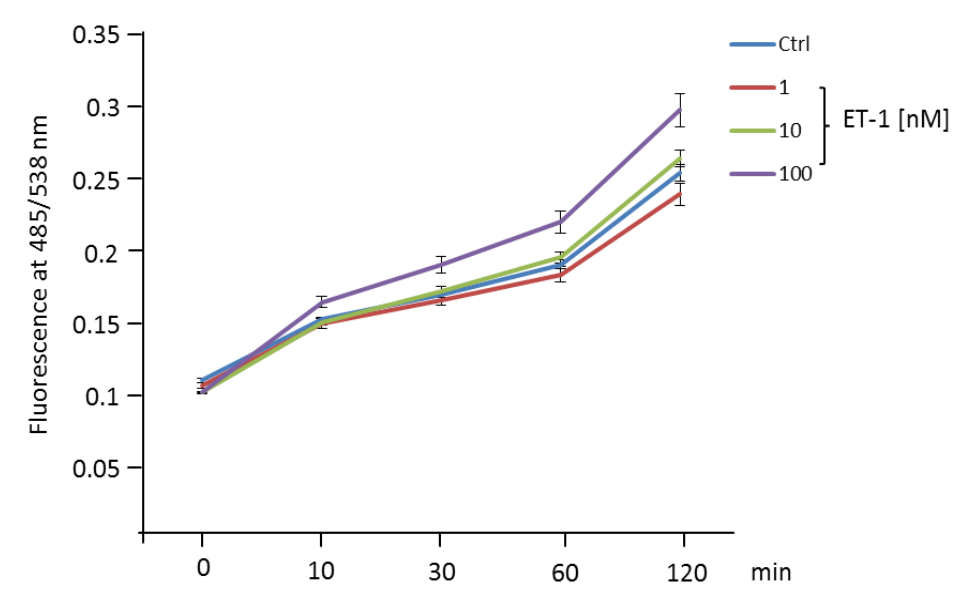

Figure 8. ROS production in MCECs upon ET-1 stimulation. Ctrl (blue): MCECs pre-incubated with DCF $(5 \mu \mathrm{M})$, kept in D-PBS (plus $1 \mathrm{~g} / \mathrm{ml}$ glucose) and without stimulation. ET-1 (1, 10, $100 \mathrm{nM})$ : MCECs pre-incubated with DCF $(5 \mu \mathrm{M})$ in D-PBS, and stimulated with ET-1 $1 \mathrm{nM}$ (red), $10 \mathrm{nM}$ (green), and $100 \mathrm{nM}$ (purple), $n=6$. 
4.1.2.2 Von Willebrand factor (vWF) and Angiopoietin-2 (Ang2) expression in MCECs

To detect vWF and Ang2 protein expression in MCECs, cells were seeded on circular glass cover slips in 12-well plates and prepared as detailed in the methods section. At baseline, both proteins showed homogeneous cellular distribution with some nuclear accumulation (Figure 9A). After one hour starvation, vWF and Ang2 were partially co-localized on the cell membrane and around-the nucleus (Figure 9B).

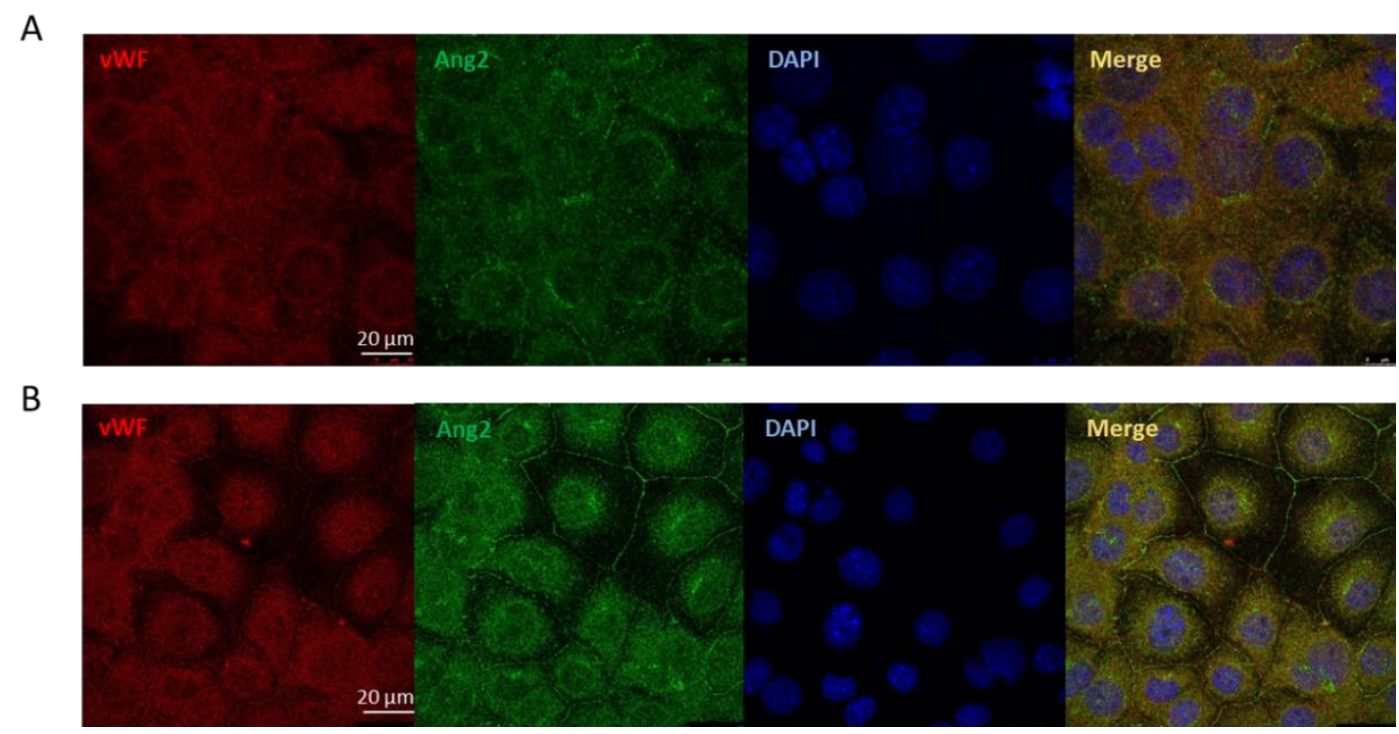

Figure 9. vWF and Ang2 expression in MCECs. A. vWF and Ang2 expression in MCECs at the basal level. B. vWF and Ang2 expression in MCECs after 1 hour of starvation. Representative images. Fluorescence: red, vWF; green, Ang2; blue, DAPI; yellow, merge. Scale bar: $20 \mu \mathrm{m}$.

\subsection{Endothelin-1 (ET-1) induced fetal gene expression in HL-1 cells}

HL-1 is a cardiac myocyte cell line that can be repeatedly passaged and yet maintain a cardiac-specific phenotype (Claycomb et al., 1998). Despite its wide application in cardiovascular research, very few studies have been conducted on the effect of ET-1 on HL-1 cells. In our study, the effects of ET-1 on ANP, BNP and $\beta$-MHC expression in HL-1 cells were analysed. 


\subsubsection{ET-1 induced fetal gene expression in HL-1 cells}

HL-1 cells were seeded in 12-well plates. When confluence was reached and the cells started to show cell contraction activity (a critical feature of cardiomyocytes), cells were kept in serum-free DMEM medium for overnight incubation. ET-1 (10, 30, 100 nM) was applied to cells the next day. After 24 hours of ET-1 stimulation, total mRNA was extracted from the cell lysate. As shown in Figure 11, both ANP and BNP mRNA expression in HL-1 cells was upregulated with ET-1 stimulation. ANP expression increased significantly with $10 \mathrm{nM}$ ET-1, and the increase was further enhanced at higher concentrations (30 and $100 \mathrm{nM}$ ). $\beta$-MHC mRNA expression was also upregulated reacting to ET-1 stimulation significantly.

A

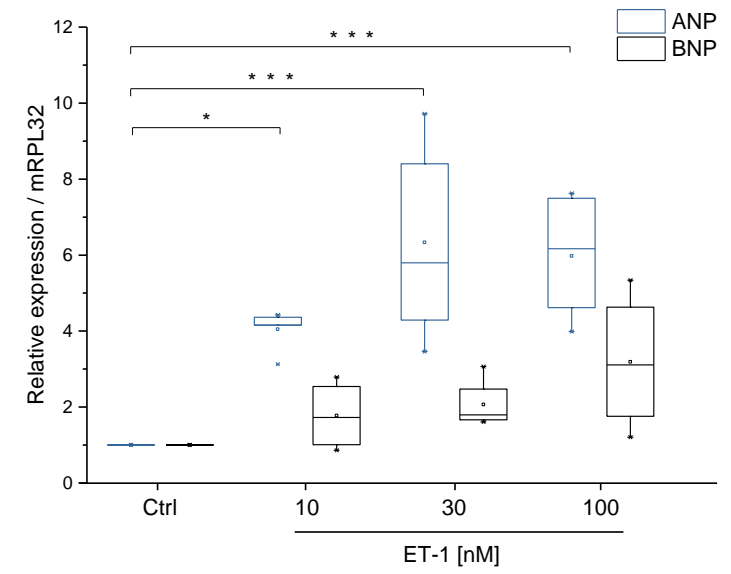

B

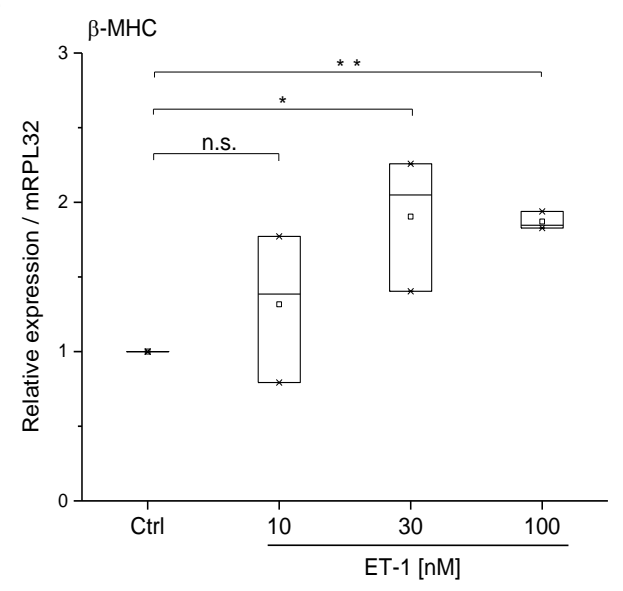

Figure 10. Fetal gene expression in HL-1 cells. Ctrl: HL-1 cells kept in serum-free DMEM medium without stimulation for 24 hours. ET-1: HL-1 cells kept in serum-free DMEM medium and stimulated with ET-1 (10, 30, $100 \mathrm{nM})$ for 24 hours. (A) ANP and BNP mRNA: $n=5$ and $n=4$, respectively; (B) $\beta$-MHC mRNA: $n=3 .{ }^{*} \mathrm{p}<0.05, * * \mathrm{p}<0.01$, *** $<<0.001$ as indicated.

\subsubsection{Endothelin-1 (ET-1) induced ANP peptide release into HL-1 cell culture supernatant}

HL-1 cell culture supernatants collected during the mRNA expression experiments were subjected to ELISA analysis, revealing that ANP peptide concentration in the supernatant significantly increased with ET-1 stimulation at $100 \mathrm{nM}$ (Figure 11). 


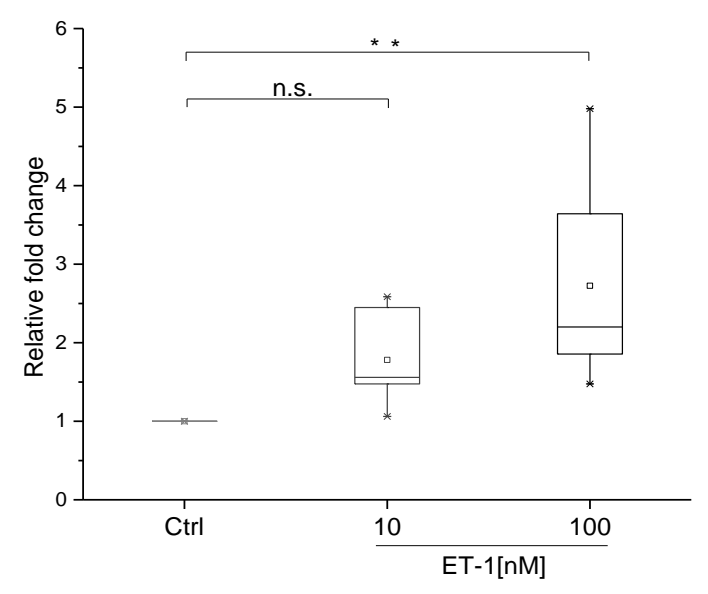

Figure 11. ANP peptide concentration in HL-1 cell culture supernatant. Ctrl: Supernatant from cells without stimulation; ET-1: Supernatant from cells exposed to ET-1 $(10,100 \mathrm{nM})$ for 24 hours, $n=6, * * \mathrm{p}<0.01$ as indicated.

\subsection{Fetal gene expression in HL-1 cells co-cultured with endothelial cells}

\subsubsection{Morphology and permeability of the endothelial cell monolayer seeded on}

\section{Falcon Transwell cell culture inserts}

MCECs were seeded on Falcon ${ }^{\circledR}$ Transwell cell culture inserts (pore size: 0.4 and 3.0 $\mu \mathrm{m})$ with a density of 0.5 million cells/well, and kept in a companion plate with cell culture medium in both the upper and lower chambers. When confluence was reached, the inserts were rinsed briefly with D-PBS and transferred to 60-mm petri-dishes. WGA membrane staining was applied to MCECs with DAPI. As shown in Figure 12A, MCECs formed a typical cobble stone monolayer on the $0.4 \mu \mathrm{m}$ pore-size PET membrane. In order to check permeability of the monolayers, FITC-dextran (40 kDa) was added to the cell culture medium for MCECs seeded on 0.4 and $3.0 \mu \mathrm{m}$ inserts. Fluorescence of the medium collected from both the upper and lower chambers after 1 hour was determined. Compared with the control group (basal medium without FITC-dextran), fluorescence of the medium from the lower chamber of the $0.4 \mu \mathrm{m}$ inserts essentially remained unchanged while that of the medium from the lower chamber of the $3.0 \mu \mathrm{m}$ inserts was clearly increased (Figure 12B). Fluorescence of the medium from the upper chambers of the inserts with both pore sizes seemed quite similar. 
A

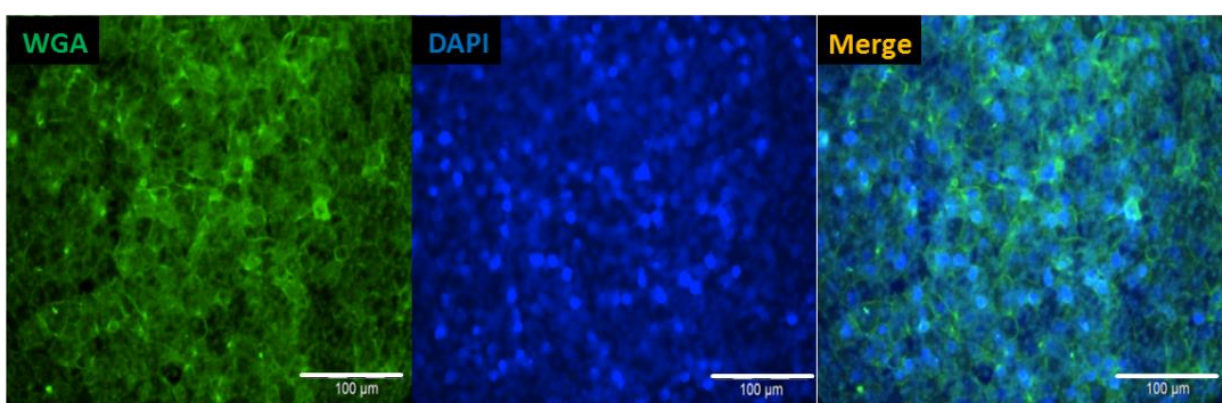

B
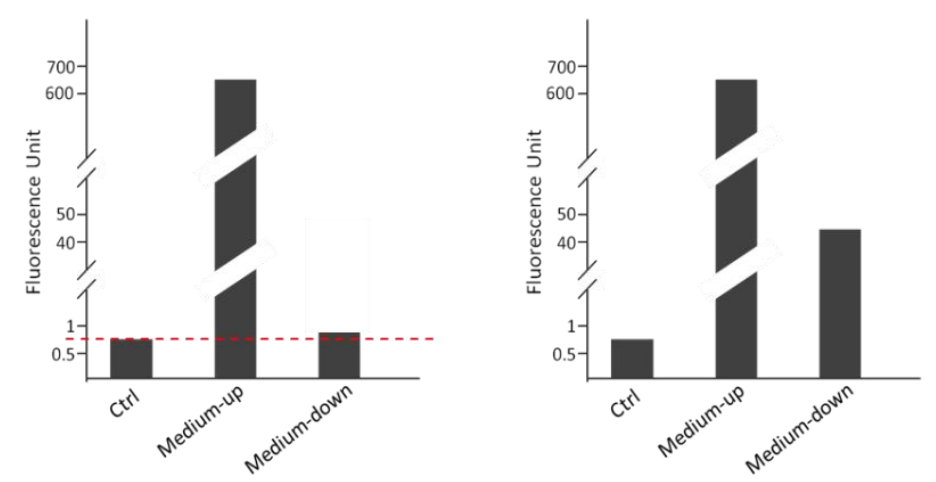

Figure 12. MCECs on Falcon Transwell cell culture inserts. A. MCEC monolayer on a 0.4 $\mu \mathrm{m}$ PET membrane. Green fluorescence: WGA; blue fluorescence: DAPI. B. Fluorescence of the medium from the upper and lower chambers of the inserts with 0.4 (left) and 3.0 (right) $\mu \mathrm{m}$ pore size. Ctrl: basal medium in companion plate without inserts and FITC-dextran (40 kDa); Medium-up: medium from upper chamber of insert with MCECs; Medium-down: medium from lower chamber of insert with MCECs.

\subsubsection{Fetal gene expression in HL-1 cells co-cultured with endothelial cells}

\subsubsection{ANP and BNP mRNA expression in HL-1 cells co-cultured with MCECs}

Two approaches of co-culture system were used in this study ( $c f$. Figure 4). In both approaches, MCECs on inserts were stimulated with or without ET-1 (100 nM) when reaching confluence. After 24 hours, total mRNA in HL-1 cells was extracted and ANP and BNP mRNA expression analysed by qRT-PCR. In the first approach, both ANP and BNP mRNA expression in HL-1 cells significantly increased when co-cultured with MCECs, and these increases were further enhanced when the MCECs had been stimulated with ET-1 (Figure 13A). In the second approach, HL-1 cell ANP mRNA expression increased significantly in a similar way as in approach 1. There also was an increase of BNP mRNA expression in HL-1 cells co-cultured with 
MCECs and a further increase upon ET-1 stimulation of the MCECs, but both effects did not reach statistical significance (Figure 13B).

A

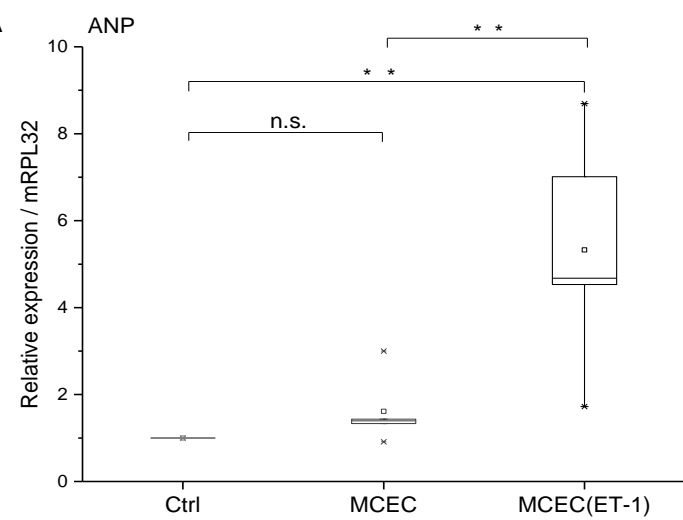

B

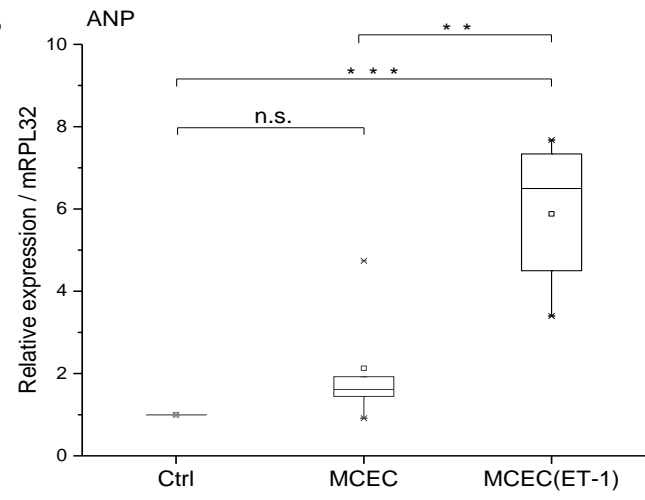

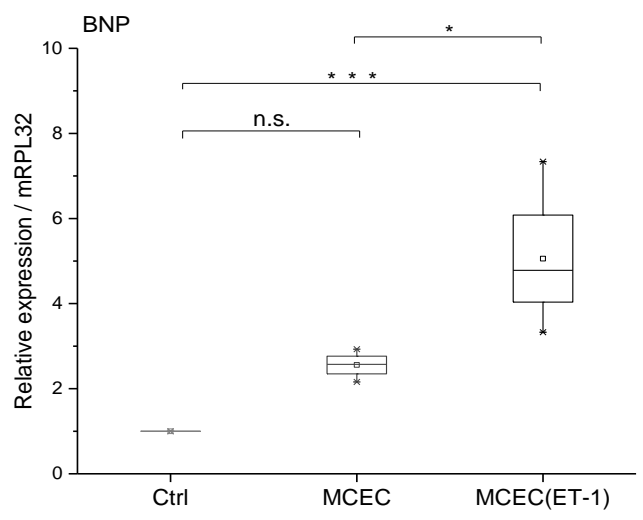
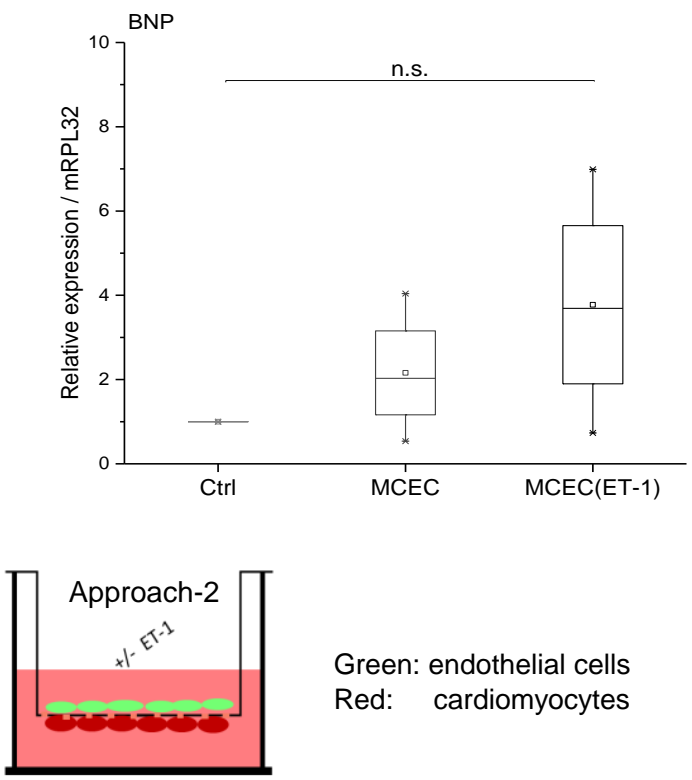

Green: endothelial cells

Red: cardiomyocytes

Figure 13. ANP (left) and BNP (right) mRNA expression in HL-1 cells co-cultured with MCECs in approach-1 (A) and approach-2 (B). A. Ctrl: HL-1 cells seeded on companion plates without transwell inserts; MCEC: HL-1 cells seeded on companion plates with MCECs on transwell inserts; MCEC (ET-1): HL-1 cells seeded on companion plates with MCECs on transwell inserts and ET-1 (100 nM) stimulation of the MCECs for 24 hours. ANP mRNA: $n=5$; BNP mRNA: $n=4$. The insert on the bottom left depicts the experimental set-up. ${ }^{*} \mathrm{p}<0.05,{ }^{*} \mathrm{p}<0.01, * * * \mathrm{p}<0.001$ as indicated. B. Ctrl: HL-1 cells seeded on the lower side of transwell inserts without MCECs on the inserts; MCEC: HL-1 cells and MCECs seeded on two sides of the transwell insert; MCEC (ET-1): HL-1 cells and MCECs seeded on two sides of the transwell insert and ET-1 $(100 \mathrm{nM})$ stimulation of MCECs for 24 hours. ANP mRNA: $n=5$; BNP mRNA: $n=4$. The insert on the bottom depicts the experimental set-up. **p $<0.01$, $* * * \mathrm{p}<0.001$ as indicated; n.s., not significant. 


\subsubsection{ANP mRNA expression in HL-1 cells co-cultured with CI-muMECs}

As shown in Figure 14, there was an upregulation of ANP mRNA expression in HL-1 cells when co-cultured with CI-muMECs, and the increase was significant with ET-1 (100 nM) stimulation of the CI-muMECs.

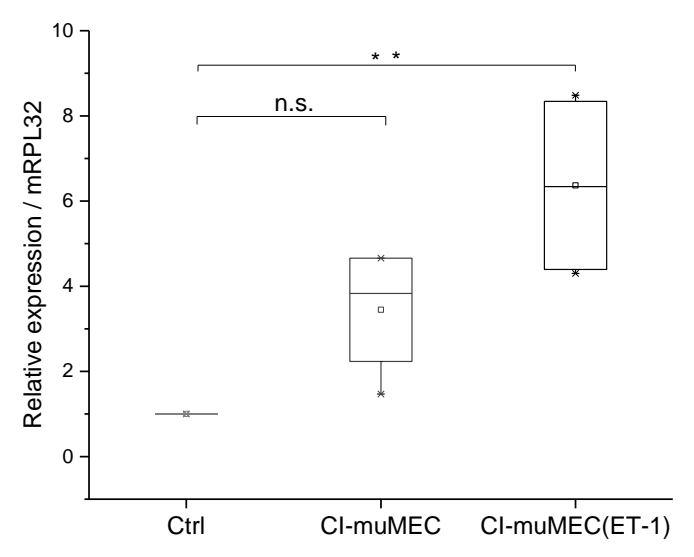

Figure 14. ANP mRNA expression in HL-1 cells co-cultured with CI-muMECs in approach-1. Ctrl: HL-1 cells seeded on companion plates without transwell inserts; CI-muMEC: HL-1 cells seeded on companion plates with CI-muMECs on transwell inserts; CI-muMEC (ET-1): HL-1 cells seeded on companion plates with CI-muMECs on transwell inserts and ET-1 $(100 \quad \mathrm{nM})$ stimulation of the CI-muMECs. $n=4, * * \mathrm{p}<0.01$ as indicated.

\subsection{Fetal gene expression in HL-1 cells co-cultured with EC-conditioned medium}

\subsubsection{ANP and BNP mRNA expression in HL-1 cells co-cultured with EC-conditioned medium}

HL-1 cells were kept in serum-free DMEM medium overnight until confluence was reached. MCEC conditioned medium with or without pre-stimulation by ET-1 of the MCECs was added to the HL-1 cells as half the volume of total cell culture medium in each group. Total mRNA in HL-1 cells was extracted after 24 hours and gene expression was analysed by qRT-PCR. There was a significant increase of ANP mRNA expression in HL-1 cells co-cultured with MCEC-conditioned medium with or without ET-1 pre-stimulation (Figure 15A left). BNP mRNA expression in HL-1 cells decreased when co-cultured with MCEC-conditioned medium while it increased in HL-1 cells co-cultured with the conditioned medium of MCECs that had been exposed to ET-1 for 24 hours before (Figure 15A right).

To exclude the possibility of remaining biological activity of ET-1 in the conditioned medium of ET-1 pre-stimulated MCECs, serum-free DMEM medium containing ET-1 
(100 nM) was kept at $37^{\circ} \mathrm{C}$ for 24 hours and then added to the cultured HL-1 cells.

Compared with the control group and ET-1 pre-stimulated group, ET-1 kept in medium at $37^{\circ} \mathrm{C}$ for 24 hours did not induce an obvious increase in ANP or BNP mRNA expression in the HL-1 cells (Figure 15B).
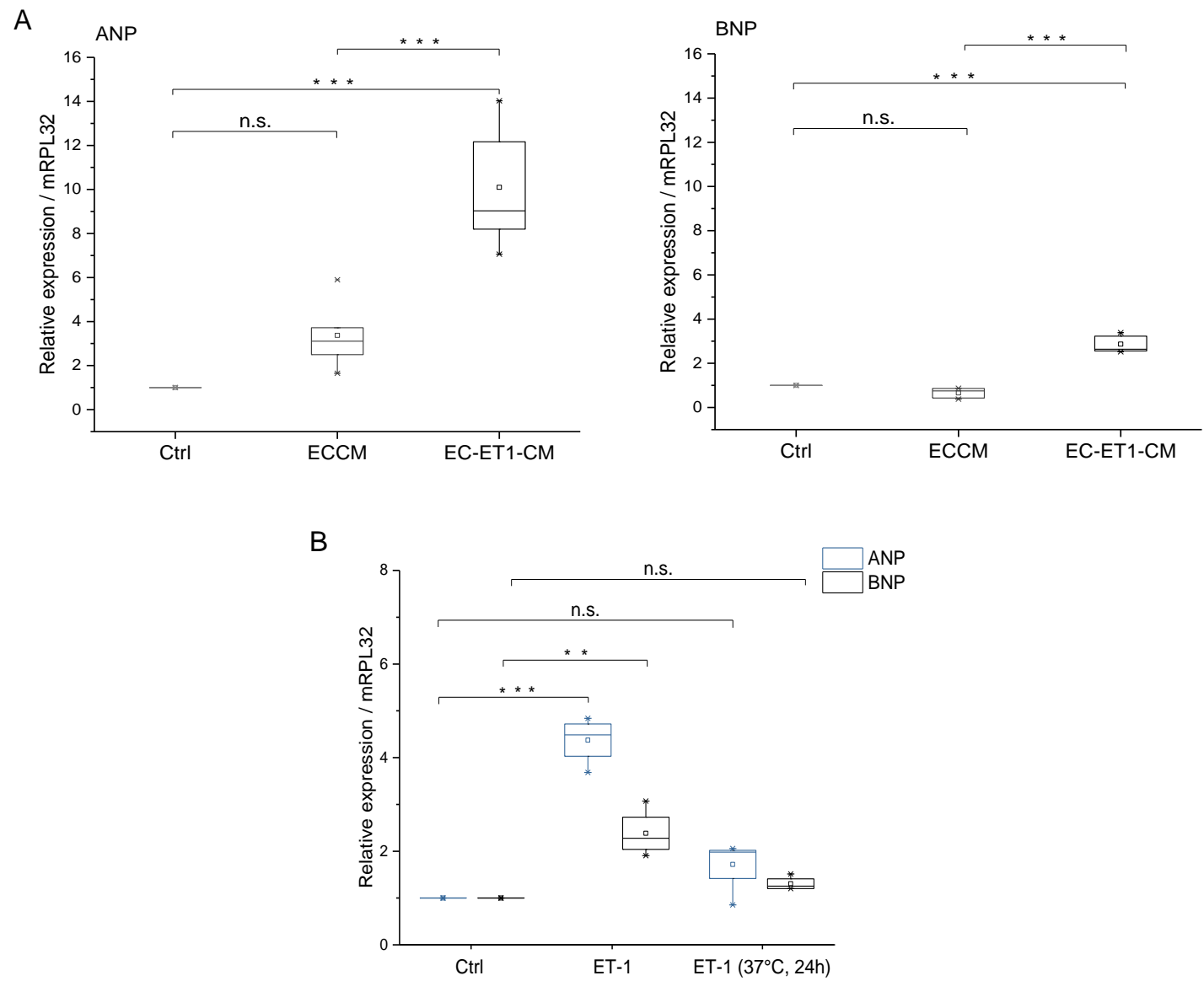

Figure 15. ANP and BNP mRNA expression in HL-1 cells exposed to MCEC-conditioned medium. A. Left: ANP mRNA; right: BNP mRNA. Ctrl: HL-1 cells kept in serum-free DMEM medium without stimulation; ECCM: HL-1 cells cultured with MCEC-conditioned medium; EC-ET1-CM: HL-1 cells cultured with ET-1 pre-stimulated MCEC-conditioned medium. $n=5$, $* * * \mathrm{p}<0.001$ as indicated B. Ctrl: HL-1 cells kept in serum-free DMEM medium; ET-1: HL-1 cells with ET-1 $(100 \mathrm{nM})$ stimulation for 24 hours; ET-1 (37 $\left.{ }^{\circ} \mathrm{C}, \mathbf{2 4 h}\right)$ : HL- 1 cells cultured with medium containing $100 \mathrm{nM}$ ET- 1 kept at $37^{\circ} \mathrm{C}$ for 24 hours. $n=3$, $* * \mathrm{p}<0.01, * * * \mathrm{p}<0.001$ as indicated; n.s., not significant; ANP and BNP mRNA levels as indicated

\subsubsection{ANP peptide release in cell culture supernatant from HL-1 cells cultured with EC-conditioned medium}

Cell culture supernatant from HL-1 cells was collected 24 hours after EC-conditioned 
medium was added. ANP peptide concentration was analysed by ELISA. There was an obvious upregulation of ANP concentration in the supernatant from HL-1 cells cultured with MCEC-conditioned medium which was significantly enhanced further upon pre-stimulation of the MCECs with ET-1 (Figure 16 left). Similar findings were obtained with the conditioned medium of CI-muMECs with ANP concentrations in the supernatant of the HL-1 cells rising significantly especially when the CI-muMECs had been pre-stimulated with ET-1 (Figure 16 right).

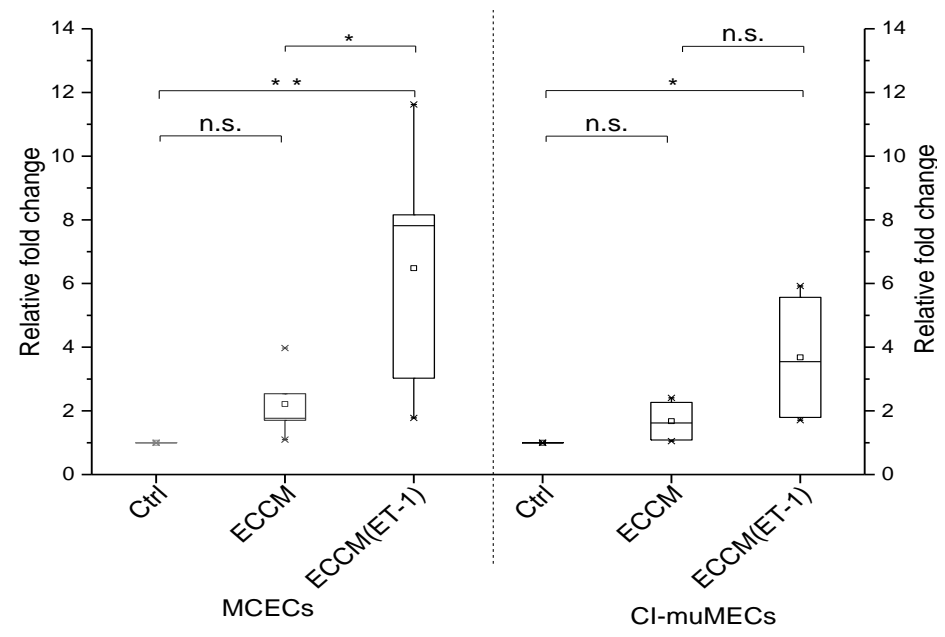

Figure 16. ANP peptide concentration in the supernatant of cultured HL-1 cells. Ctrl: Supernatant from HL-1 cells cultured with serum-free DMEM medium; ECCM: Supernatant from HL-1 cells cultured with EC-conditioned medium; ECCM(ET-1): Supernatant from HL-1 cells cultured with the conditioned medium of ECs pre-stimulated with ET-1 (100 nM) for 24 hours. $n=5, * \mathrm{p}<0.05, * * \mathrm{p}<0.01$ as indicated

\subsection{Analysis of EC-conditioned medium}

\subsubsection{Rough fractionation of the EC-conditioned medium according to molecular} mass

To classify the contents in the EC-conditioned medium affecting HL-1 cell gene expression by molecular weight (MW), MCEC-conditioned medium was concentrated with filtration through Vivaspin ${ }^{\circledR}$ centrifugal concentrators (membrane exclusion pore size: 10, 30 and $50 \mathrm{kDa}$ ). Compared with basal conditioned medium, fractionated medium with contents exceeding a MW of 10,30 or $50 \mathrm{kDa}$ maintained the effect of inducing ANP mRNA expression in the HL-1 cells. Fractions containing contents with 
smaller MW did not show this effect (Figure 17).
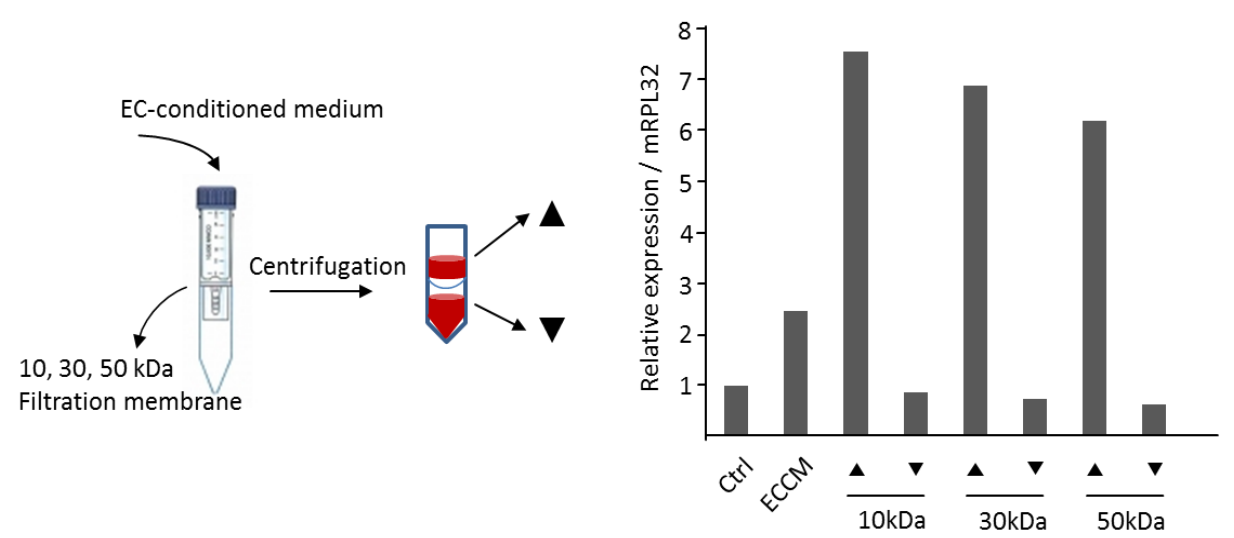

Figure 17. ANP mRNA expression in HL-1 cells with fractionated MCEC-conditioned medium. Filtration membrane pore size: 10,30 and $50 \mathrm{kDa}$; Concentrator capacity: $6 \mathrm{ml}$; Spin Speed: $3000 \times g, 10-15 \mathrm{~min}$; $\boldsymbol{\Delta}$ Fraction containing contents with MW larger than membrane pore size, concentration ratio: around 5 to $1 ; \boldsymbol{\nabla}$ Fraction containing contents with MW smaller than membrane pore size. Representative experiment (right) with the principle illustrated on the left.

\subsubsection{SDS-PAGE analysis of EC-conditioned medium}

Concentrated (10 kDa Vivaspin ${ }^{\circledR}$ centrifugal concentrator) MCEC-conditioned medium with and without prior ET-1 stimulation was separated by SDS-PAGE followed by staining of the gel with Coomassie blue resulted in concentration of a band with a MW of around $60 \mathrm{kDa}$ (Figure 18A). On a second SDS-PAGE, human recombinant angiopoietin-2 (MW: $57 \mathrm{kDa}, \mathrm{Hr}-\mathrm{Ang} 2)$ was loaded followed by Western blot analysis with a specific anti-Ang2 antibody, yielding a band on the blot with a very similar MW than the Coomassie blue-stained band on the SDS-PAGE (Figure 20B). To further confirm whether the contents of the bands from the EC-conditioned medium mainly consisted of Angiopoietin-2, control, ECCM and ET-1-stimulated ECCM were blotted as well, yielding visible bands of a similar size also with the mouse ECCM (Figure 18B). 

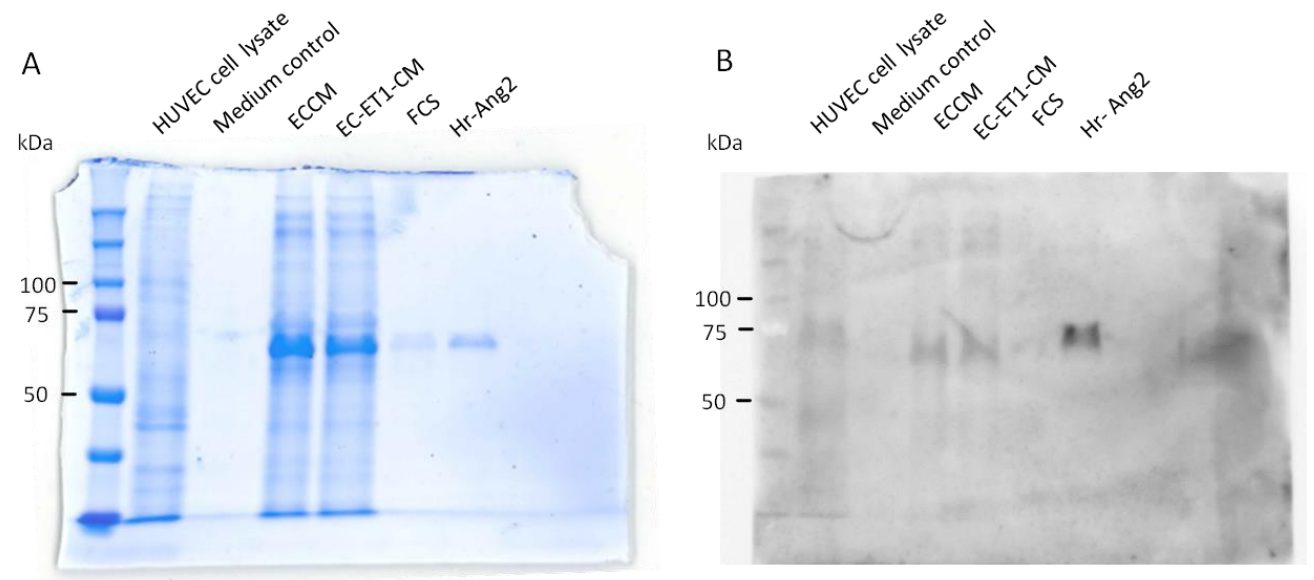

Figure 18. SDS-PAGE analysis of MCEC-conditioned medium. A. Coomassie blue staining of SDS-PAGE gel, protein loading: $10 \mu \mathrm{g}$. B. Western blot PVDF membrane stained with anti-Ang2 antibody, protein loading: $10 \mu \mathrm{g}$. Medium control: serum-free DMEM medium; ECCM: MCEC-conditioned medium (concentrated); EC-ET1-CM: medium of MCECs prior stimulated with $100 \mathrm{nM}$ ET-1 for 24 hours (concentrated); Hr-Ang2: Human recombinant angiopoietin-2, $5 \mu \mathrm{g}$; FCS: foetal bovine serum; HUVEC: human umbilical vein endothelial cells. Representative experiments.

\subsection{Angiopoietin-2 and endothelin-1 co-effects on fetal gene expression in HL-1 cells}

\subsubsection{ANP mRNA expression in HL-1 cells}

Next, expression of the Ang2 receptor Tie1/2 in HL-1 cells was analysed by qRT-PCR.

The crossing point for Tie1 receptor cDNA in the PCR program was larger than 33, which is considered below the detectable range. Moreover, there was a significant decrease of Tie2 receptor mRNA expression in HL-1 cells co-cultured with MCECs compared with that at the basal level (Figure 19A). Ang2 was added to HL-1 cells at different concentrations $(0.1$ to $10 \mathrm{ng} / \mathrm{ml})$, with or without ET-1 $(100 \mathrm{nM})$, and cells were harvested after 24 hours for further analysis. As shown in Figure 19B, there was a decrease of ANP mRNA expression in HL-1 cells exposed to Ang2 at concentrations higher than $1 \mathrm{ng} / \mathrm{ml}$. There was an upregulation of ET-1 (100 nM) induced ANP mRNA expression in the presence of $1 \mathrm{ng} / \mathrm{ml}$ Ang2 while a decrease was seen with 10 ng/ml Ang2. 


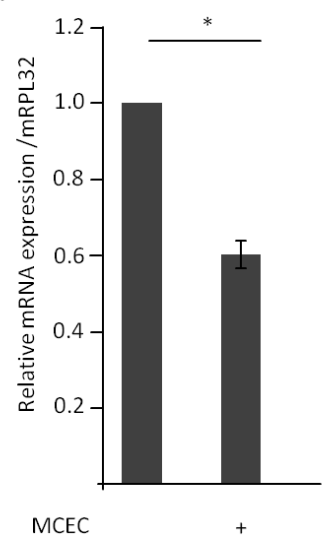

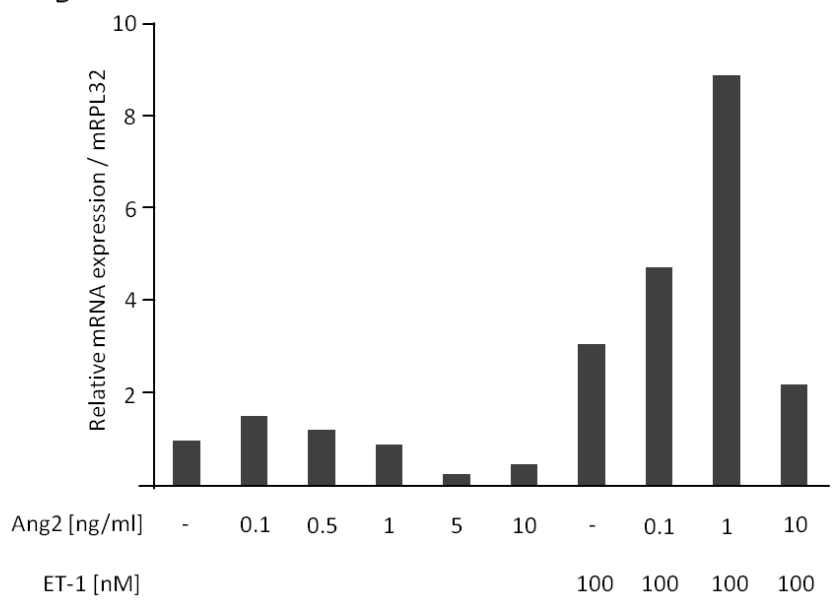

Figure 19. The effect of Angiopoietin-2 on ANP mRNA expression in HL-1 cells. A. Tie2 receptor mRNA expression in HL-1 cells, +: HL-1 cells co-cultured with MCECs in approach-1, $n=3, * p<0.05$. B. ANP mRNA expression in HL-1 cells in the absence or presence of Ang2 (as indicated) with or without co-stimulation with ET-1 (100 nM). Representative experiment.

\subsubsection{Effects of Angiopoietin-2 on endothelin-1-stimulated ANP mRNA expression in HL-1 cells}

To further explore the effect of Ang2 on ET-1 induced ANP mRNA expression in HL-1 cells, Ang2 (1 ng/ml) was applied to cells 30 min prior to ET-1 (10, 30, $100 \mathrm{nM})$ stimulation, and cells were harvested 24 hours later. ANP mRNA expression in HL-1 cells increased with increasing ET-1 concentrations. Pre-incubation with $1 \mathrm{ng} / \mathrm{ml}$ Ang2 provoked a significant enhancement of ET-1-induced ANP expression at $10 \mathrm{nM}$. Stimulation with higher concentrations of ET-1 (30, $100 \mathrm{nM})$ revealed a slight but insignificant decrease in ANP mRNA expression following pre-incubation with 1 ng/ml Ang2 (Figure 20A). Higher concentrations of Ang2 (10 ng/ml) significantly decreased ET-1-induced ANP mRNA expression in HL-1 cells (Figure 20B). 

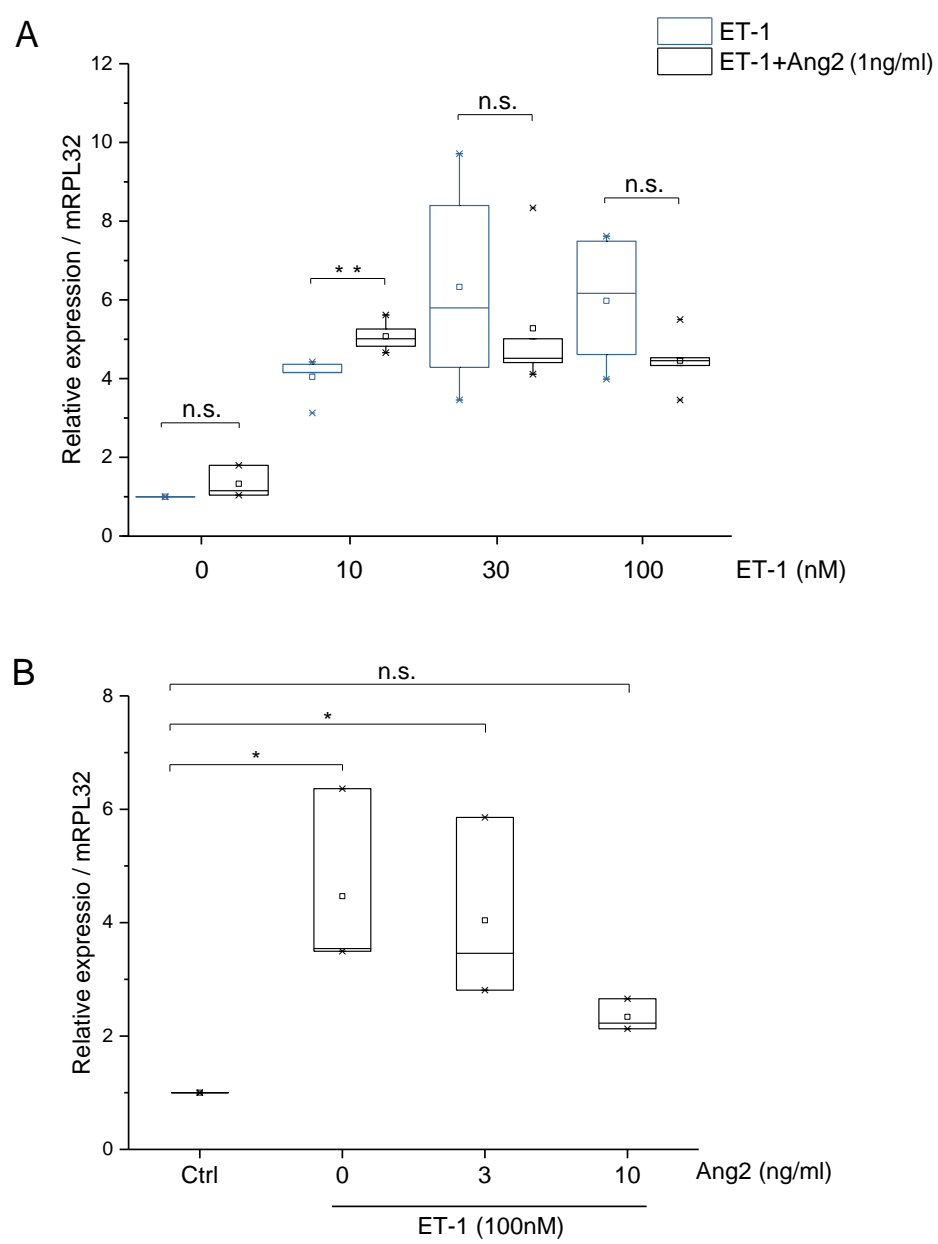

Figure 20. Angiopoietin-2 affects Endothelin-1-induced ANP mRNA expression in HL-1 cells. A. ANP mRNA expression in HL-1 cells pre-incubated with Ang2 (1 ng/ml) and stimulated with ET-1 $(10,30,100 \mathrm{nM})$ afterwards, $n=5$, $* * \mathrm{p}<0.01$ as indicated; n.s., not significant. B. ANP mRNA in HL-1 cells pre-incubated with Ang2 (3, $10 \mathrm{ng} / \mathrm{ml})$ and stimulated with ET-1 (100 nM) afterwards, $n=3$, *p<0.05as indicated; n.s., not significant.

\subsubsection{ANP peptide concentration in cell culture supernatant from HL-1 cells cultured with Angiopoietin-2 and Endothelin-1}

Cell culture supernatant from HL-1 cells stimulated with ET-1 (10, $100 \mathrm{nM})$ with or without Ang2 (1 ng/ml) pre-incubation was collected 24 hours after stimulation. Consistent with the increased ANP expression at the mRNA level, Ang2 (1 ng/ml) pre-incubation had a pronounced but not yet significant augmenting effect on ANP peptide release from HL-1 cells induced by 10 nM ET-1 (Figure 21). 


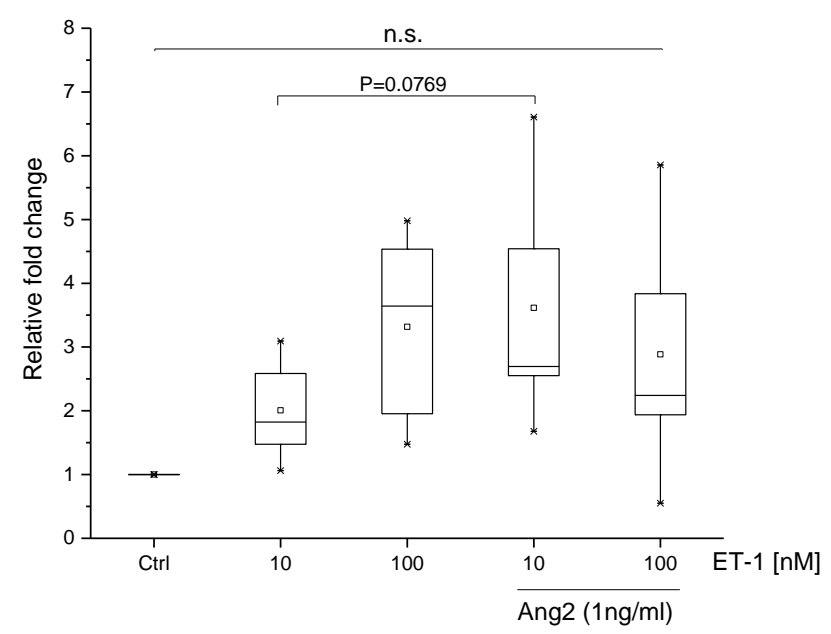

Figure 21. ANP peptide concentration in the supernatant of cultured HL-1 cells. Ctrl: Supernatant from HL-1 cells cultured in serum-free DMEM medium, without stimulation. ET-1: Supernatant from HL-1 cells cultured in serum-free DMEM medium with or without Ang2 (1 ng/ml) exposure $30 \mathrm{~min}$ prior to ET-1 (10, $100 \mathrm{nM})$ stimulation for 24 hours. $n=6$; n.s., not significant.

4.7 The role of nuclear factor of activated T-cells (NFAT) in endothelial cell-cardiomyocyte interaction

\subsubsection{NFAT activity inhibition in endothelial cell-cardiomyocyte interaction}

To investigate whether the calcineurin-NFAT pathway plays a role in EC-conditioned medium (ECCM) induced ANP expression in HL-1 cells, FK506, a calcineurin activity inhibitor (Sieber and Baumgrass, 2009), was applied to HL-1 cells $30 \mathrm{~min}$ before adding the EC-conditioned medium. FK506 (100 nM) pre-incubation did not show much effect on ECCM-induced ANP mRNA expression in HL cells. There was a clear but just not significant decrease of ET-1-enhanced ECCM-mediated ANP mRNA expression by FK506 (Figure 22). 


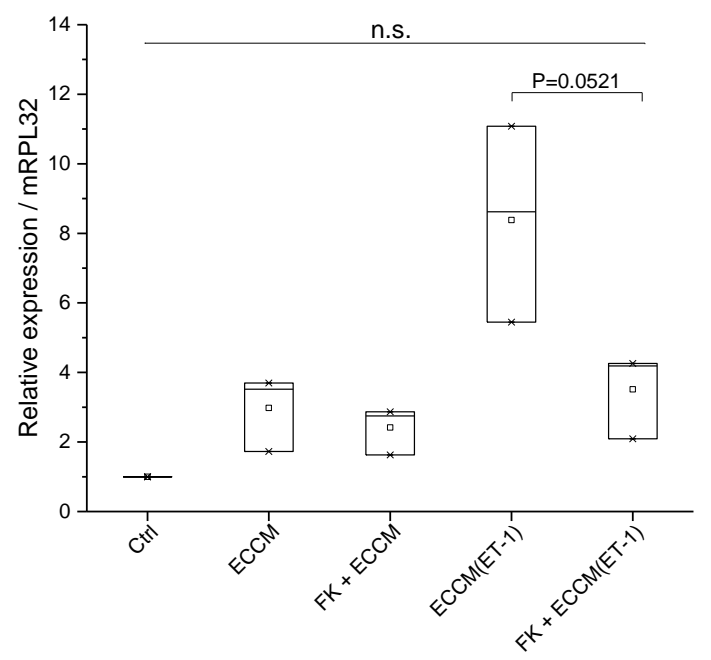

Figure 22. ANP mRNA expression in HL-1 cells cultured with MCEC-conditioned medium with and without NFAT inhibition. Ctrl: HL-1 cells cultured in serum-free DMEM medium; ECCM: HL-1 cells cultured with MCEC-conditioned medium; FK+ECCM: HL-1 cells cultured with MCEC-conditioned medium and pre-incubation with FK506 (100 nM); EC-ET1-CM: HL-1 cells cultured with ET-1 (100 nM) pre-stimulated MCEC-conditioned medium; FK+EC-ET1-CM: HL-1 cells cultured with ET-1 (100 nM) pre-stimulated MCEC-conditioned medium and FK506 pre-treatment. $n=3$; n.s., not significant.

\subsubsection{Vascular endothelial growth factor C (VEGF-C) release in EC-conditioned medium}

The release of VEGF-C, a calcineurin-NFAT pathway related ligand, by endothelial cells, was analysed by ELISA. MCECs and CI-muMECs were kept in serum-free DMEM medium upon reaching confluence. After overnight starvation, ET-1 (100 nM) was applied to the cells and conditioned medium collected after 4 and 24 hours with and without stimulation by ET-.1. VEGFR2 and VEGFR3 mRNA expression were detected by qRT-PCR. There was some decrease in receptor expression in HL-1 cells stimulated with ET-1 (10, $100 \mathrm{nM})$ (Figure 23A). In the MCEC culture supernatant there was a time-dependent accumulation of VEGF-C peptide that was not affected by ET-1 (100 nM) stimulation (Figure 23B). In the conditioned medium of CI-muMECs, VEGF-C peptide was not detectable. 

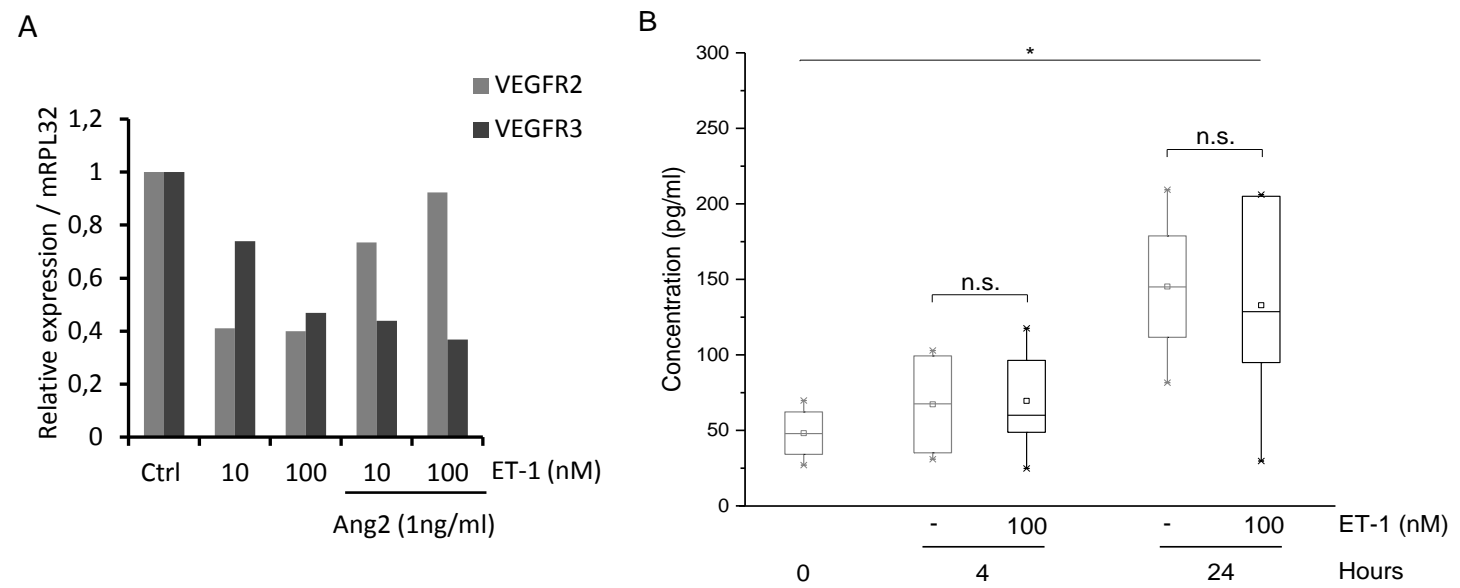

Figure 23. VEGF receptor expression in HL-1 cells and VEGFC concentration in the conditioned medium of MCECs. A. VEGFR2 and VEGFR3 mRNA expression in HL-1 cells with or without Ang2 (1 ng/ml) and ET-1 (10, $100 \mathrm{nM})$ stimulation, $n=2$. B. VEGF-C peptide concentrations in the supernatant of MCECs after 4 and 24 hours exposure to ET-1 $(100 \mathrm{nM}), n=5 ; * \mathrm{p}<0.05$ as indicated; n.s., not significant.

\subsection{Qualitative mass spectrometry analysis of EC-conditioned medium}

4.8.1 Gene ontology annotation of proteins detected in EC-conditioned medium by mass spectrometry

Conditioned medium from MCECs and CI-muMECs was concentrated with $10 \mathrm{kDa}$ Vivaspin ${ }^{\circledR}$ centrifugal concentrators. From each sample, $5 \mathrm{ml}$ of conditioned medium was concentrated to around $100 \mu \mathrm{l}$, with a final protein concentration corresponding to $0.5-1.0 \mu \mathrm{g} / \mu \mathrm{l}$. For each group, 3 samples from independent experiments were prepared. Mass spectrometry results were analysed with DAVID Bioinformatics Resources 6.8 (NIH, US). Distinctively presented proteins identified in the control and ET-1 (100 nM) stimulated groups were categorized with Gene Ontology (GO) annotation. Proteins were grouped into three well-established GO categories, known as cellular components, biological process and molecular function.

There were 265 proteins identified in MCEC-conditioned medium at baseline of which 33 proteins were distinctively present, mainly associated with the extracellular exosome and proteolysis (Figure 24A). After ET-1 stimulation 347 proteins were identified of which 73 were distinctively presented, mostly related with protein 
folding and protein binding (Figure 24B). In CI-muMEC-conditioned medium, there were 538 proteins identified at baseline of which 68 were distinctively presented, mainly associated with transport and nucleotide binding (Figure 24C). After ET-1 stimulation, 472 proteins were identified in the supernatant of which 68 were distinctively present, mostly involved in RNA binding and splicing (Figure 24D).
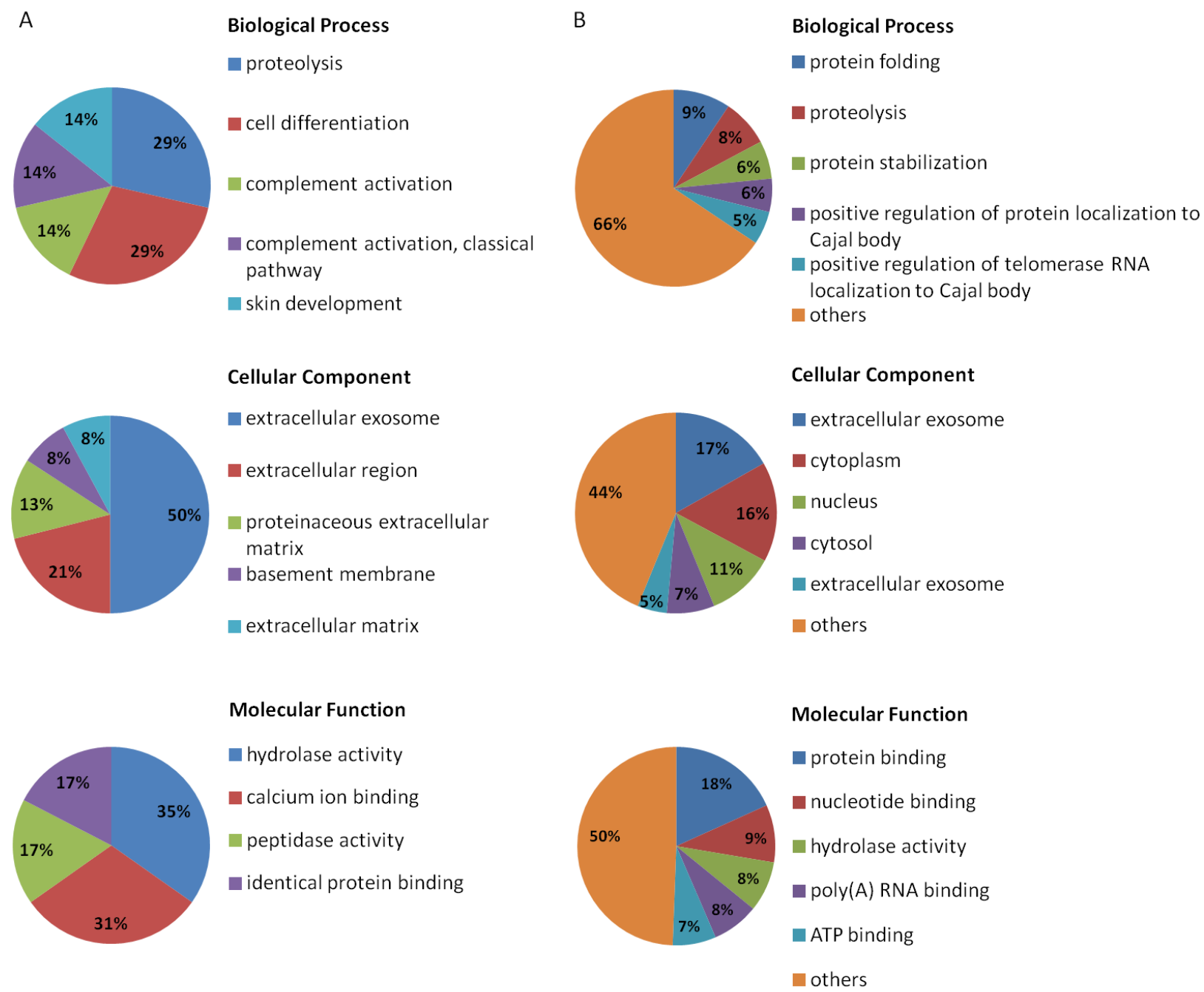


$$
\text { C }
$$
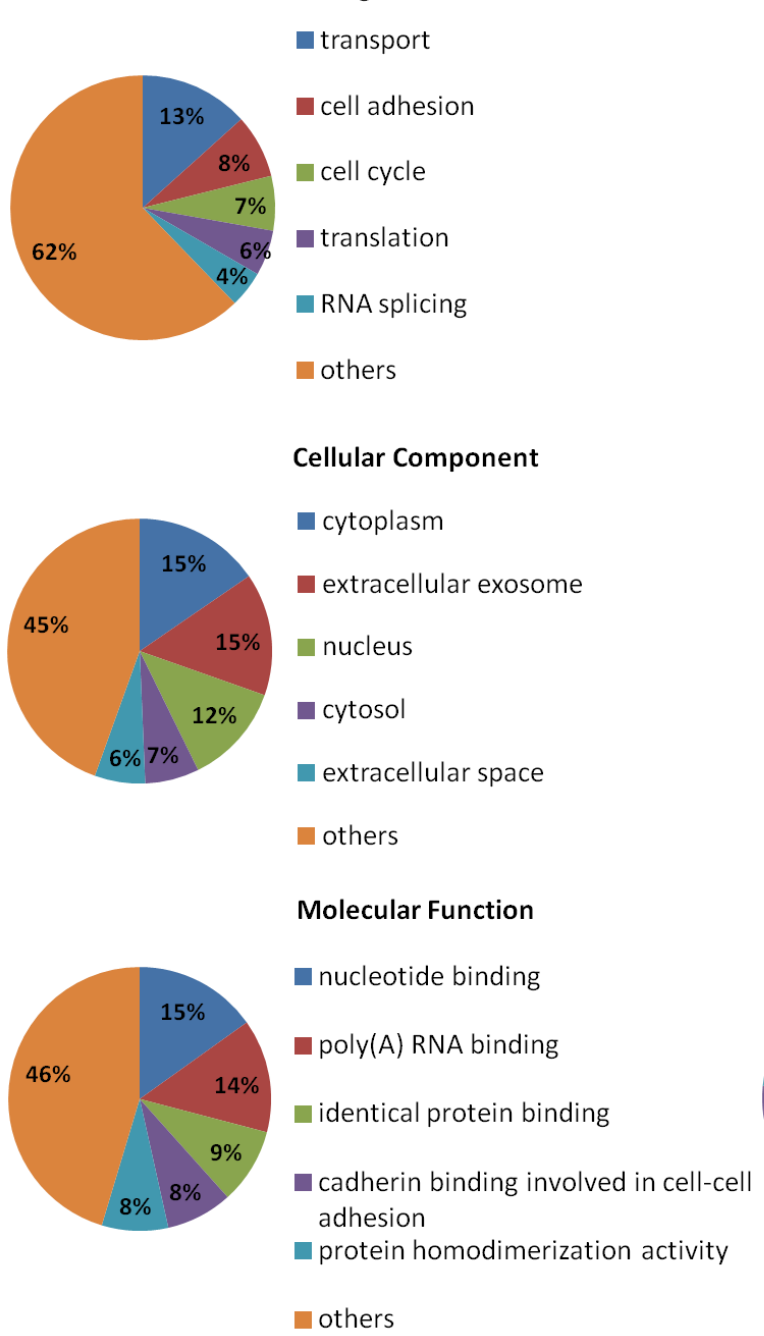

D

Biological Process

rNA splicing

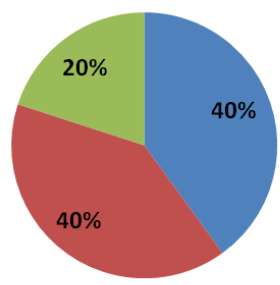

mRNA processing

alternative mRNA splicing, via spliceosome
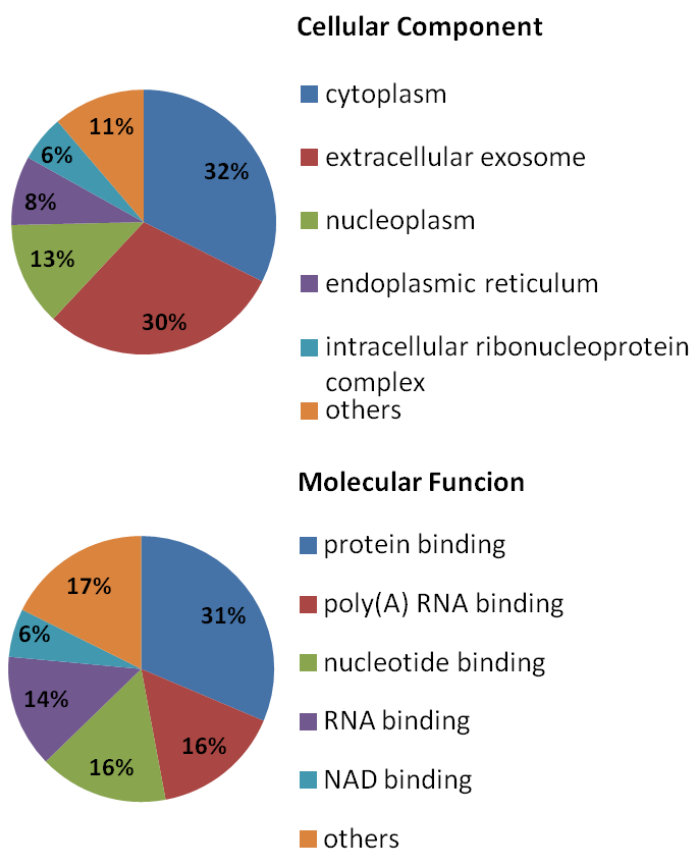

Figure 24. GO annotation of distinctively present proteins in each group of MCEC and CI-muMEC supernatants with or without ET-1 (100 nM) stimulation. A. Proteins distinctively present in MCEC supernatant at baseline. B. Proteins distinctively present in MCEC supernatant after ET-1 stimulation. C. Proteins distinctively present in CI-muMEC supernatant at baseline. D. Proteins distinctively present in CI-muMEC supernatant after ET-1 stimulation. Average percentages of $n=3$ individual experiments for each group.

\subsubsection{Gene functional classification of differently released proteins in EC-conditioned medium}

Functional clusters of distinctively present proteins in EC-conditioned medium were analysed with DAVID Bioinformatics Resources 6.8 (Table 11). Cluster 1 and 2 were formed from the most abundant proteins identified in the secretome of MCECs at baseline and following ET-1 (100 nM) stimulation, cluster 3 from those present in the 
secretome of quiescent CI-muMECs, and cluster 4 of the most abundant proteins in the secretome of ET-1 (100 nM) stimulated CI-muMECs.

Tab.11: Functional clusters of distinctively present proteins identified in the different EC secretomes

\begin{tabular}{lll}
\hline Cluster-1 & $\begin{array}{l}\text { Uniprot } \\
\text { Accession }\end{array}$ & Protein \\
\hline P21107 & tropomyosin 3, gamma (Tpm3) \\
P47753 & $\begin{array}{l}\text { capping protein (actin filament) muscle Z-line, alpha } \\
\text { Q6apza1) }\end{array}$ \\
P58771 & tropomyosin 4 (Tpm4) \\
\hline
\end{tabular}

\begin{tabular}{lll}
\hline Cluster-2 & $\begin{array}{l}\text { Uniprot } \\
\text { Accession }\end{array}$ & Protein \\
\hline Q8BGZ7 & keratin 75 $(\mathrm{Krt75})$ \\
Q972T6 & keratin 85 $(\mathrm{Krt} 85)$ \\
P02535 & keratin 10 $(\mathrm{Krt10})$ \\
Q9ERE2 & keratin 81 $(\mathrm{Krt} 81)$ \\
Q61897 & keratin 33B (Krt33b) \\
Q497I4 & keratin 35 $(\mathrm{Krt35})$ \\
\hline
\end{tabular}

\begin{tabular}{lll}
\hline Cluster-3 & $\begin{array}{l}\text { Uniprot } \\
\text { Accession }\end{array}$ & Protein \\
\hline O35737 & heterogeneous nuclear ribonucleoprotein H1 \\
& $($ Hnrnph1) \\
& P49312 & heterogeneous nuclear ribonucleoprotein A1 \\
& $($ Hnrnpa1) \\
\hline
\end{tabular}


Q8VIJ6 splicing factor proline/glutamine rich

(polypyrimidine tract binding protein associated)

(Sfpq)

P29341 poly(A) binding protein, cytoplasmic 1 (Pabpc1)

\begin{tabular}{lll}
\hline Cluster-4 & $\begin{array}{l}\text { Uniprot } \\
\text { Accession }\end{array}$ & Protein \\
\hline O35737 & heterogeneous nuclear ribonucleoprotein H1 \\
& $($ Hnrnph1) \\
P49312 & heterogeneous nuclear ribonucleoprotein A1 \\
& $($ Hnrnpa1) \\
Q8VIJ6 & splicing factor proline/glutamine rich \\
& $($ polypyrimidine tract binding protein associated) \\
& $($ Sfpq $)$ \\
& poly(A) binding protein, cytoplasmic 1 (Pabpc1) \\
\hline
\end{tabular}




\section{Discussion}

\subsection{Characterization of endothelial cells}

\subsubsection{Characterization of CI-muMECs}

VCAM-1 and ICAM-1 are well-known cell surface proteins expressed in endothelial cells, playing important roles during inflammation and endothelial cell-leukocyte interaction. Expression of both proteins had been indicated in pulmonary microvascular endothelial cells (Xue et al., 2017, Sievert et al., 2015). MCP-1 is one of the key chemokines that play an important role in the diapedesis of monocytes and their differentiation to macrophages (Deshmane et al., 2009). NO, a critical cardiovascular signalling molecule, can be generated by three different isoforms of the enzyme NO synthase (NOS). The endothelial NOS (NOS3 or eNOS), is mostly expressed in endothelial cells (Forstermann and Sessa, 2012). Nitrite is a central homeostatic molecule in NO biology and serves as an important signalling molecule in its own right (Bryan et al., 2005). Nitrite and nitrate levels in blood have been widely used as an index of endothelial NO synthase activity (Bryan and Grisham, 2007, Kleinbongard et al., 2003).

$\mathrm{TNF} \alpha$ and IFN $\gamma$ are cytokines that play an important role in endothelial cell activation and dysfunction. Previous work indicated that expression of adhesion molecules such as VCAM-1, ICAM-1 and E-selectin or chemokines by microvascular endothelial cells is upregulated upon exposure to these cytokines (Zhang, 2008, Pober and Sessa, 2007). NO production was also reported to be correlated with the effect of these cytokines (Dinarello, 2007). In our study, VCAM-1, ICAM-1 and MCP-1 mRNA expression in CI-muMECs increased significantly with cytokine stimulation and there was a slight decrease of NOS3 mRNA expression. These results were in accordance with the known effects of these cytokines on macrovascular endothelial cells. Furthermore, there was a significant increase of VCAM-1 abundance on CI-muMECs 24 hours after cytokines stimulation.

Under physiological conditions, endothelial cells are exposed to mechanical forces 
caused by the flowing blood and the beating heart (Davies, 1995). Among these forces, shear stress appears to be a particularly important hemodynamic force. It stimulates the release of vasoactive substances, namely that of NO, and regulates gene expression, cell metabolism, and cell morphology (Davies, 1995, Traub and Berk, 1998). In our study, NOS3 protein expression by CI-muMECs cultured in the presence of fluid shear stress increased compared to the basal level, and there was a significantly higher concentration of nitrite, as an indirect measure of NO release in the supernatant. Combined with the decrease of NOS3 mRNA levels following cytokine stimulation, NOS3 activity and expression as well as their response to pro-inflammatory cytokines seem to be regulated normally in these conditionally immortalised murine microvascular ECs.

\subsubsection{Characterization of MCECs}

When exposed to endothelin-1, MCECs revealed an increased production of ROS, presumably mainly peroxides, ROS and oxidative stress are important features of cardiovascular diseases including atherosclerosis, hypertension, and congestive heart failure (Sugamura and Keaney, 2011). Endothelium-derived ROS may also contribute to cardiac remodelling (Zhang and Shah, 2014). The enhanced ROS signal detected in MCECs upon ET-1 stimulation suggested such a possible effect also on the HL-1 cells they have been co-cultured with. In this context, it would be interesting to be able to detect the ROS signal for more than 120 min. Keeping cells in proper condition for longer time during detection would be a critical point. Optimization of solvent of DCF-DA during incubation and fluorescence detection period might improve cellular performance in future experiments.

Angiopoietin-2 has been extensively investigated in angiogenesis and inflammation. Angiogenesis and inflammation are common companion conditions in the process of cardiac hypertrophy (Shiojima et al., 2005); however little is known about Ang2 expression and its regulation in cardiac microvascular ECs. Von Willebrand factor is an adhesive and multimeric glycoprotein extensively studied during haemostasis 
(Peyvandi et al., 2011). Since the first report about its expression by cardiac microvascular endothelial cells in the 1990s (Aird et al., 1997, Edelberg et al., 1998), only few studies have been conducted regarding its regulation in the heart. In the MCECs, both Ang2 and vWF were highly abundant with homogeneous distribution in the cytoplasm. After one hour of starvation, there was an obvious accumulation of both proteins on the cell membrane as compared to quiescent cells, indicating that both proteins may share a similar route of transportation in the cell upon serum removal stress. MCECs, on the other hand, did not express appreciable amounts of NOS3 or reacted to FSS by increasing the formation/release of NO.

\subsection{Endothelin-1 induced fetal gene expression in HL-1 cells}

Previous studies demonstrated that ET-1 plasma levels correlate with the development of cardiac hypertrophy (Liu et al., 2017, Xu et al., 2017). In fact, ET-1 has been widely used to induce cardiac remodelling (Archer et al., 2017, Viero et al., 2016) or as a stimulus to study hypertrophy-related pathways (Seidlmayer et al., 2016, Irvine et al., 2013). Little was known about the effect of ET-1 on HL-1 cells. ANP protein abundance in HL-1 cells was markedly enhanced 48 hours post ET-1 stimulation (Hong et al., 2011). In our experiments, ANP mRNA expression significantly increased upon exposure to $10 \mathrm{nM}$ ET-1, and the increment became greater with higher concentrations. Also BNP mRNA expression increased upon ET-1 stimulation but not as avidly as that of ANP. Although ANP and BNP are closely related natriuretic peptide hormones, clinical trials (Grandi et al., 2004, Rubattu et al., 2006, Uusimaa et al., 2004) suggest that their plasma levels correlate with different parameters such as diastolic dysfunction and ventricular hypertrophy. In our hands, ANP and BNP expression in HL-1 cells reacted differently to ET-1 stimulation, a finding compatible with previous results by another group (Sergeeva and Christoffels, 2013). Also upregulated was $\beta$-MHC expression in response to ET-1 stimulation, providing further evidence to support a reprogramming of gene expression in the HL-1 cells. 


\subsection{Fetal gene expression in HL-1 cells co-cultured with endothelial cells}

\subsubsection{HL-1 cell-endothelial cell co-culture system}

Co-culturing cells, namely on a Transwell insert within a companion plate, is a well-established model to investigate cell-cell interactions in vitro (Sattayaprasert et al., 2016, Heiss et al., 2015). As described in the methods section, two co-culture approaches were used in this study. In both approaches, pores in the Transwell membrane allowed molecules released from endothelial cells, which were seeded on top of the insert, to diffuse to the other side of the membrane and further into the bottom chamber. Moreover, in the approach in which HL-1 cells were seeded on the lower side of membrane, the pores in the membrane provided the possibility for a direct physical contact of the two cell types on each side of the membrane.

From experience in our laboratory, human umbilical vein endothelial cells seeded on the PET membrane form a tight monolayer upon reaching confluence. In the present co-culture experiments, MCECs seeded on the Transwell inserts with $0.4 \mu \mathrm{m}$ and 3.0 $\mu \mathrm{m}$ pore size also formed a cobblestone-like monolayer upon reaching confluence, which was in line with basic endothelial cell characteristics.

The vascular endothelium is permeable for molecules from $0.1 \mathrm{~nm}$ to $11.5 \mathrm{~nm}$ in diameter. Two transport mechanisms were defined for solute/ion influx into the vessel wall through the EC monolayer: The transport of macromolecules larger than $3 \mathrm{~nm}$, such as albumin, $\operatorname{IgG}$, and others, via the transcellular pathway, also referred to as transcytosis or vesicular transport. Molecules smaller than $3 \mathrm{~nm}$, such as glucose, water, and ions, can pass through inter-endothelial junctions via the paracellular pathway (Sukriti et al., 2014). In our study, permeability of the MCEC monolayer on the Transwell inserts was evaluated with FITC-labelled dextran of $40 \mathrm{kDa}$ which has an estimated molecule diameter of $4.5 \mu \mathrm{m}$. As expected, monolayers on the 3.0- $\mu \mathrm{m}$ pore size membrane showed much higher permeability compared with that on the 0.4- $\mu \mathrm{m}$ pore size membrane. Considering the molecule diameter of the FITC-labelled dextran used, the rather high permeability of the MCEC monolayer on the 3.0- $\mu \mathrm{m}$ 
pore size membrane may have been due to impaired inter-endothelial junctions. In order to have a reasonably tight monolayer, therefore, only the $0.4-\mu \mathrm{m}$ pore size membrane was used in further experiments.

\subsubsection{ANP and BNP mRNA expression in HL-1 cells co-cultured with endothelial cells}

As delineated in the introduction section, microvascular endothelial cells and cardiomyocytes interact through multiple pathways under physiological and pathophysiological conditions. The secretome of microvascular cardiac ECs contribute largely to the maintenance of proper cardiomyocyte function (Coppiello et al., 2015, Parodi and Kuhn, 2014, Paulus and Tschope, 2013). In our study, after co-culturing with MCECs for 24 hours, ANP and BNP expression in HL-1 cells was upregulated in both co-culture settings, suggesting that a component within the MCEC secretome induces or reinforces induction of the fetal gene program in the cardiomyocyte cell line.

With ET-1 stimulation of MCECs, ANP and BNP expression in HL-1 cells was markedly upregulated compared to untreated MCECs. ET-1 stimulation apparently induced a change in the MCEC secretome that further enhanced transcription of the $A N P$ and BNP genes in the HL-1 cells. A similar effect was seen when instead of MCECs the supernatant of ET-1-stimulated CI-muMECs was employed.

A study by Nolan et al. (Nolan et al., 2013) suggests that there is tissue/organ-specific heterogeneity of microvascular endothelial cells with respect toclusters of transcription factors, angiocrine growth factors, adhesion molecules, and chemokines that are expressed in unique combinations by such ECs of different organs. In fact, the MCECs which are of cardiac origin displayed a different gene expression pattern than the CI-muMECs which are derived from the lungs. Nonetheless does the ET-1-stimulated secretome of both microvascular endothelial cell types contain a similar humoral factor or factors that induces or reinforces the fetal gene program in 
HL-1 cells.

\subsection{Fetal gene expression in HL-1 cells co-cultured with endothelial cell conditioned medium}

As discussed above, the endothelial cell monolayer on the Transwell inserts with $0.4-\mu \mathrm{m}$ pore size showed very little permeability for FITC-labelled dextran. ET-1 has a much smaller molecular mass $(2.5 \mathrm{kDa})$ than the $40 \mathrm{kDa}$ dextran preparation used and hence a smaller size (1.9 $\mathrm{nm}$ as compared to $4.5 \mathrm{~nm}$ ). To exclude the possible effect of a leak of ET-1 from the upper to the lower chamber through the Transwell filter insert, ET-1 at a concentration of $100 \mathrm{nM}$ dissolved in serum-free DMEM medium was kept at $37^{\circ} \mathrm{C}$ for 24 hours to facilitate its decomposition. When compared to freshly added ET-1 at the same concentration, the serum-free DMEM had very little if any effect on ANP and BNP expression by the HL-1 cells, suggesting that it is not any excess ET-1 leaking through the Transwell filter that caused the effect of the EC-conditioned medium on HL-1 cell gene expression.. As a consequence, next the nature of the factor or factors in the EC-conditioned medium was investigated assuming that it probably is a polypeptide or protein.

\subsection{Analysis of EC-conditioned medium}

\subsubsection{EC-conditioned medium fractionation by molecular weight}

Application of centrifugal concentrators has been reported to be a practical method to concentrate and fractionate cell culture supernatant by molecular weight (Saha et al., 1992, Zimmermann et al., 2011). First, the EC-conditioned medium was fractionated by concentrators with exclusion sizes of 10, 30 and $50 \mathrm{kDa}$. ANP mRNA expression in HL-1 cells increased significantly with fractions containing polypeptides or proteins larger than 10,30 or $50 \mathrm{kDa}$. The effect exerted by the fractionated EC-conditioned medium was much larger than that induced by the unfractionated EC-conditioned medium, which may have been due to the concentration (approximately 5 times) of the medium during the filtration step. The flow through 
fractions did not affect ANP mRNA expression in the HL-1 cells. As suggested by the technical service from the supplier (Sartorius), the pore size of the filters could provide a rough estimate of the molecular weight of the contents separated by the filter, but cannot serve as a distinct cut-off. Nonetheless, these results strongly indicated that the polypeptide factor in the MCEC-conditioned medium that induces ANP mRNA expression in the HL-1 cells should be equal to or larger than 50kDa.

\subsubsection{SDS-PAGE analysis of EC-conditioned medium}

This fractionation of the EC-conditioned medium also offered the possibility to have enough protein in the concentrated fraction for SDS-PAGE analysis. Coomassie blue staining delineated several bands from 10 to up to $100 \mathrm{kDa}$ but there was no appreciable difference in staining intensity between bands detected in the fractionated EC-conditioned medium and the fractionated conditioned medium of MCECs pre-incubated with ET-1, suggesting that the method may not be sensitive enough.

Among proteins $\geq 50 \mathrm{kDa}$ known to be released by microvascular cells, angiopoietin-2 plasma levels have been reported to correlate with cardiac function (Lukasz et al., 2013, Poss et al., 2015). Therefore, human recombinant Ang2 (Hr-Ang2) was subjected to SDS-PAGE followed by Western blot analysis, and produced a band with a similar size than a murine protein of about $60 \mathrm{kDa}$ detected in theMCEC-conditioned medium, insinuating that this may in fact contain Ang2. Therefore, the potential role of MCEC-derived Ang2 in inducing or reinforcing ANP and BNP expression by HL-1 cells was investigated further.

\subsection{Angiopoietin-2 and endothelin-1 co-effect on fetal gene expression in HL-1 cells}

Despite the extensively studied role of Ang2 in angiogenesis, very little is known about its effect on cardiomyocytes. In one study (Greulich et al., 2012) cardiomyocytes treated with secretory products from epicardial adipose tissue of 
patients with type 2 diabetes mellitus that was enriched in Ang2 caused reductions in sarcomere shortening, cytosolic calcium fluxes, and expression of sarcoplasmic endoplasmic reticulum ATPase 2a.

Since there were no reports about Ang2 receptor expression in HL-1 cells, we measured these ourselves. While Tie1 mRNA levels were below the detection limit of the qRT-PCR, Tie2 mRNA expression was significantly decreased in HL-1 cells co-cultured with MCECs, indicating that a secreted protein such as Ang2 may have activated the HL-1 cell Tie2 receptors. Exposure of the HL-1 cells to authentic Ang2 caused a concentration-dependent decrease in ANP expression while ET-1-induced ANP expression was augmented by low concentrations of Ang2 (1 ng/ml) but inhibited by high concentrations of Ang2 (10 ng/ml). Tie2 receptor activation in endothelial cells is linked to pro-inflammatory signalling pathways (Milam and Parikh, 2015), while the Ang2-dependent signal transduction in cardiomyocytes is not yet clear. Moreover, Ang2 plasma concentration has been reported to be associated with cardiovascular disease (Nadar et al., 2005, Tabit et al., 2016). Due to these varying, concentration-dependent effects of authentic Ang2 on basal or ET-1-stimulated MCEC-mediated induction of the fetal gene program in the HL-1 cells, it is difficult to conclude that (i) Ang2 is in fact the humoral factor present in the MCEC-conditioned medium and (ii) how this is effect is brought about by Ang2 in the cardiomyocyte cell line. Further experiments are required to elucidate this point. In this regard, a neutralising anti-Ang2 antibody did not significantly attenuate the stimulatory effect of the EC-conditioned medium with or without ET-1 pre-stimulation on ANP expression by the HL-1 cells.

\subsection{The role of NFAT in endothelial cell-cardiomyocyte interaction}

NFAT is an extensively studied transcription factor family in cardiac remodelling (Corban et al., 2017, Bakthavatsalam et al., 2014) that is generally activated upon dephosphorylation in the cytoplasm by the calcium-dependent phosphatase calcineurin. In our study, a calcineurin inhibitor, FK506, had no effect on the 
MCEC-conditioned medium-dependent upregulation of ANP mRNA in the HL-1 cells but downregulated the additional effect of the conditioned medium from MCECs pre-stimulated with ET-1. Increased NFAT activity is mainly involved in pathophysiological cardiac remodelling rather than physiological remodelling induced, e.g. by endurance sports (Clerk et al., 2007). In this context, induction of the fetal gene program in the HL-1 cells by the conditioned medium of ET-1-stimulated endothelial cells might be achieved through different cellular signalling mechanisms than that mediated by the conditioned medium of quiescent endothelial cells. Activation of NFAT through the calcium-calcineurin pathway may be responsible in part for this difference.

VEGF-C is a calcineurin-NFAT pathway related ligand known to be released by endothelial cells, the concentration of which in the conditioned medium of quiescent or ET-1-pre-stimulated MCECs did not differ. Although there was a ET-1-mediated decrease in expression of the VEGF receptors 2 and 3 that are both targeted by VEGF-C, this finding essentially excludes VEGF-C, despite a fitting molecular mass, as the humoral factor which mediates the prominent stimulatory effect of the conditioned medium of ET-1-pre-stimulated ECs on HL-1 cell expression of fetal genes such ANP, BNP or $\beta$-MHC. On the other hand, it does not exclude the possibility that VEGF-C like Ang2 contributes to ANP and BNP mRNA expression in the HL-1 cells induced by the conditioned medium from quiescent microvascular ECs.

\subsection{Mass spectrometry analysis of EC-conditioned medium}

\subsubsection{Gene ontology annotation of proteins detected in EC-conditioned medium} by mass spectrometry

In an alternative approach to identify candidate polypeptides present in the conditioned medium of the ECs, mass spectrometry analysis was used which provides this possibility (Hu et al., 2016). Gene ontology (GO) annotation allows for the interpretation of the potential involvement of a specific protein within a group of 
proteins with similar biological function (Gene Ontology, 2015). Thus analysed, the majority of proteins detected in the EC-conditioned medium could be classified into three well established GO categories: biological process(es), cellular component and molecular function. Moreover, proteins released from quiescent and ET-1-stimulated MCECs are frequently found in exosomes. While the most abundant proteins in the secretome of quiescent MCECs are associated with proteolysis, those in the secretome of ET-1-pre-stimulated MCECs are involved in protein folding and binding. Proteins detected in the secretome of quiescent or ET-1-stimulated CI-muMECs represented mainly cytoplasmic or exosomal proteins. While the former are mostly related with transport and cell adhesion, the latter are associated mainly with RNA processing and splicing.

Exosomes are extracellular vesicles containing key mediators of intercellular communication. Previous studies demonstrated that cardiac progenitor cells, HUVECs, and mesenchymal stem cells derived exosomes modulate cardiac function (Barile et al., 2017, Wang et al., 2017a). The results of our mass spectrometry analysis suggest that the secretome of the microvascular ECs contains exosomal proteins and thus perhaps whole exosomes. In addition, they support the notion of a cellular heterogeneity among microvascular ECs from different tissue/organ origin.

\subsubsection{Gene functional classification of distinctively presented proteins in EC-conditioned medium}

The DAVID Gene Functional Classification tool uses an agglomeration algorithm to condense a list of genes or associated biological terms into organized classes of related genes or biology, called biological modules (Huang et al., 2007). In our study, it served as a tool to classify functionally related proteins into biological modules for better interpretation of the microvascular EC secretome. Clusters (groups of proteins) characteristic for the conditioned medium of quiescent and ET-1-stimulated CI-muMECs comprised different members of heterogeneous nuclear ribonucleoproteins (hnRNPs), i.e. RNA-protein complexes present in the nucleus 
during gene transcription and post-transcriptional modification of pre-mRNA. There is no evidence for a direct link between hnRNPs and pathophysiological cardiac remodelling (hypertrophic cardiomyopathy). However, one member of the hnRNP family, HnRNPA2B1, has been shown to be in charge of micro-RNA loading into exosomes (Villarroya-Beltri et al., 2013). Two other hnRNP family members, hnRNPA1 and hnRNPC, can also bind to exosomal miRNAs, suggesting that they might be candidates for miRNA sorting as well (Zhang et al., 2015).

MicroRNAs continue to spark interest in the process of cardiac hypertrophy. Thus, miR-22, a cardiac- and skeletal muscle-enriched microRNA, was found to be upregulated during myocyte differentiation and cardiomyocyte hypertrophy, and overexpression of miR-22 was sufficient to induce cardiomyocyte hypertrophy (Huang et al., 2013). Cardiac-specific overexpression of miR-206 in mice also induced hypertrophy but protected the heart from ischemia/reperfusion injury, whereas suppression of miR-206 exacerbated ischemia/reperfusion injury and prevented pressure overload-induced cardiac hypertrophy (Yang et al., 2015). Combined with the GO cellular component annotation, our findings may support the concept that exosomes containing functional RNAs play important role in endothelial cell-cardiomyocyte interaction. Furthermore, the effect of hnRNPs on RNA sorting and transport might link them to the process of cardiac hypertrophy, and make them a potentially interesting target for future manipulation of microvascular EC-cardiomyocyte interaction.

\subsubsection{Pathway analysis of distinctively presented proteins in EC-conditioned medium}

The DAVID Pathway analysis function also provided the possibility to connect a list of proteins with up-to-date intercellular and extracellular signalling pathways from established pathway databases (such as KEGG). There were numerous pathways comprising proteins from our input list. In consideration of cell-cell communication, pathways containing ligand-receptor interaction(s) would be particularly interesting. 
In this context, two components of complement $\mathrm{C} 1$, the complex that initiates the classical pathway of complement activation, C1/r (90 kDa) and C1/s (80 kDa), could be potential mediators of the stimulatory effect of EC-conditioned medium on HL-1 cell fetal gene expression. One study showed that overexpression of $\mathrm{C} 1 / \mathrm{r}$ and $\mathrm{C} 1 / \mathrm{s}$ induces cardiac hypertrophy in mice (Yang et al., 2007). In our study, both C1/r and $\mathrm{C} 1 / \mathrm{s}$ were present in the secretome of quiescent MCECs which is at variance with some of the previous findings. However, they whet the appetite for further investigations in this direction. 


\section{Summary}

The anatomic arrangement of microvascular endothelial cells and cardiomyocytes in vivo enables close interactions among these cells. In our in vitro co-culture system, ANP and BNP mRNA expression in cardiomyocytes and subsequent ANP release were significantly upregulated when co-cultured with endothelial cells or exposed to endothelial cell-conditioned medium. Combined with previous results indicating a crucial role for ANP and BNP in cardiac homeostasis, our finding provide further evidence that paracrine signalling by cardiac microvascular endothelial cells modulates cardiomyocyte function.

Endothelin-1 (ET-1) activation of endothelial cells remarkably enhanced their paracrine effects on cardiomyocyte gene expression in our study, suggesting for the first time that ET-1 stimulation of endothelial cells affects expression of fetal genes such as ANP and BNP in adult cardiomyocytes through paracrine signalling. Elevated plasma levels of ET-1 are observed during hypertension and cardiac hypertrophy, and microvascular activation and inflammation have been reported to accompany cardiac hypertrophy. The present results further confirm the importance of an intact microvascular homeostasis for the pathogenesis of such complex cardiac disease processes and might provide a basis for future therapeutic strategies targeting microvascular endothelial cell-cardiomyocyte interaction during cardiac hypertrophy. Such a strategy may comprise inhibition of the calcineurin-NFAT pathway in the cardiomyocytes which herein selectively inhibited the stimulatory effect on cardiomyocyte fetal gene expression by the conditioned medium derived from ET-1-pre-stimulated endothelial cells.

The importance of keeping the balance between angiogenesis and cardiomyocyte growth during cardiac hypertrophy has frequently been addressed in the past. In our study, angiopoietin-2 (Ang2) alone or in combination with exogenous ET-1 affected cardiomyocyte ANP expression and release in a concentration-dependant manner. In consideration of elevated plasma levels of Ang2 in patients with acute or chronic heart 
failure, these results may spur further studies on the role of Ang2 in cardiac remodelling processes.

Mass spectrometry analysis of endothelial cell-conditioned media revealed qualitative differences in the release of proteins from endothelial cells with and without ET-1 stimulation. Gene ontology annotation of the detected proteins points towards a role for exosomes and proteins involved in RNA folding in endothelial cell-cardiomyocyte crosstalk. Based on previous findings of a role for micro-RNAs in this type of cell-to-cell communication, endothelial cell-derived exosomal micro-RNAs may not only mediate part of the biological effects of the microvascular endothelial cell-conditioned medium described herein but also provide a basis to targeting such potentially maladaptive endothelial cell-cardiomyocyte interactions in the future. 


\section{Zusammenfassung}

Mikrovaskuläre Endothelzellen und Kardiomyozyten sind zwei Zelltypen, welche in vivo in anatomisch in direktem Kontakt zueinander stehen, was nahelegt, dass diese Zellen miteinander interagieren. In unseren in vitro Co-kultur Experimenten haben wir in Kardiomyozyten eine signifikante Zunahme der ANP und BNP mRNA Expression, sowie der darauf folgenden ANP Sekretion feststellen können, wenn Kardiomyozyten entweder zusammen mit Endothelzellen kultiviert wurden, oder mit Endothelzell-konditioniertem Medium behandelt wurden. In Verbindung mit früheren Ergebnissen, welche auf eine entscheidende Rolle für ANP und BNP in der Erhaltung der kardiale Homöostase hindeuten, liefern unsere Ergebnisse weitere Beweise, dass parakrine Signalwege der kardialen mikrovaskulären Endothelzellen die Funktion von Kardiomyozyten modellieren.

Gabe von Endothelin-1, welches Endothelzellen aktiviert, konnte in unseren Versuchen den parakrin vermittelten Effekt auf die Genexpression der Kardiomyozyten verstärken, was Endothelin-1 Stimulation als bisher unbekannten Faktor in der parakrinen Signalübertragung zu adulten Kardiomyozyten über die Expression fötaler Gene wie ANP und BNP, nahelegt. Erhöhte Endothelin-1 Plasmakonzentrationen wurden bereits in der Vergangenheit bei Hypertonie und ventrikuläre Hypertrophie festgestellt. Gleichsam wurden mikrovaskuläre Aktivierung und Entzündung zusammen mit diesen Krankheitsbildern gefunden. Die gezeigten Ergebnisse bestätigen wie wichtig die mikrovaskuläre Homöostase in der Pathogenese dieser komplexen kardialen Erkrankungen ist und könnte die Entwicklung neuer therapeutischer Ansätze ermöglichen, welche die mikrovaskulären Endothelzellen und ihre Interaktion mit Kardiomyozyten ins Ziel fassen. Ein möglicher Ansatz könnte die Inhibition des Calcineurin-NFAT Signalwegs sein. Diese Inhibition unterbindet die Aktivierung der Expression fötaler Gene in Kardiomyozyten, nachdem diese mit konditioniertem Medium von Endothelin-1-aktivierten Endothelzellen behandelt wurden. 
Schon in zahlreichen Studien wurde die Balance zwischen Angiogenese und Kardiomyozytenwachstum im Zusammenhang mit Hypertrophie untersucht. In unserem Experiment hat Angiopoitin-2 alleine oder in Kombination mit exogenem Endothelin-1 einen konzentrationsabhängigen Effekt auf die Kardiomyozytenexpression und Sekretion von ANP. Da die Angiopoietin-2 Konzentration im Plasma von Patienten mit akuter oder chronischer Herzinsuffizienz erhöht ist, könnten unsere Ergebnisse weitere Studien anregen, welche die Rolle von Angiopoietin-2 im kardialen Remodelling-Prozess behandeln.

Die massenspektrometrische Analyse von Zellkulturmedium, in welchem Endothelzellen kultiviert wurden, zeigen deutliche qualitative Unterschiede im Proteingehalt, wenn die Endothelzellen zuvor mit Endnothelin-1 stimuliert wurden im Vergleich $\mathrm{zu}$ nicht stimulierten Endothelzellen. Anschließend durchgeführte genontologische Untersuchungen der detektierten Proteine deuten darauf hin, dass diese wichtig für Bildung von Exosomen, RNA-Faltung und Endothelzell-Kardiomyozyten-Interaktionen sind.

Es ist bekannt, das Mikro-RNA in dieser Art der Zell-zu-Zell Kommunikation involviert sind. Es ist daher möglich, dass exosomale Mikro-RNA aus Endothelzellen nicht nur den hier Beschriebenen Effekt haben, sondern ein potentielles Ziel darstellen um künftig fehlerhafte Endothelzell-zu-Kardiomyozyten-Kommunikation zu behandeln. 


\section{References}

ADELBORG, K., HORVATH-PUHO, E., ORDING, A., PEDERSEN, L., TOFT SORENSEN, H. \& HENDERSON, V. W. (2017). Heart failure and risk of dementia: a Danish nationwide population-based cohort study. Eur J Heart Fail 19, 253-260.

AIRD, W. C. (2007). Phenotypic heterogeneity of the endothelium: I. Structure, function, and mechanisms. Circ Res 100, 158-173.

AIRD, W. C. (2012). Endothelial cell heterogeneity. Cold Spring Harb Perspect Med 2, a006429.

AIRD, W. C., EDELBERG, J. M., WEILER-GUETTLER, H., SIMMONS, W. W., SMITH, T. W. \& ROSENBERG, R. D. (1997). Vascular bed-specific expression of an endothelial cell gene is programmed by the tissue microenvironment. J Cell Biol 138, 1117-1124.

ALONSO-GONZALEZ, R., BORGIA, F., DILLER, G. P., INUZUKA, R., KEMPNY, A., MARTINEZ-NAHARRO, A., TUTAREL, O., MARINO, P., WUSTMANN, K., CHARALAMBIDES, M., SILVA, M., SWAN, L., DIMOPOULOS, K. \& GATZOULIS, M. A. (2013). Abnormal lung function in adults with congenital heart disease: prevalence, relation to cardiac anatomy, and association with survival. Circulation 127, 882-890.

ARCHER, C. R., ROBINSON, E. L., DRAWNEL, F. M. \& RODERICK, H. L. (2017). Endothelin-1 promotes hypertrophic remodelling of cardiac myocytes by activating sustained signalling and transcription downstream of endothelin type A receptors. Cell Signal 36, 240-254.

BAKTHAVATSALAM, D., SOUNG, R. H., TWEARDY, D. J., CHIU, W., DIXON, R. A. \& WOODSIDE, D. G. (2014). Chaperonin-containing TCP-1 complex directly binds to the cytoplasmic domain of the LOX-1 receptor. FEBS Lett 588, 2133-2140.

BARBIERI, S. S., RUGGIERO, L., TREMOLI, E. \& WEKSLER, B. B. (2008). Suppressing PTEN activity by tobacco smoke plus interleukin-1beta modulates dissociation of VE-cadherin/beta-catenin complexes in endothelium. Arterioscler Thromb Vasc Biol 28, 732-738.

BARBIERI, S. S. \& WEKSLER, B. B. (2007). Tobacco smoke cooperates with interleukin-1beta to alter beta-catenin trafficking in vascular endothelium resulting in increased permeability and induction of cyclooxygenase-2 expression in vitro and in vivo. FASEB J 21, 1831-1843.

BARILE, L., MOCCETTI, T., MARBAN, E. \& VASSALLI, G. (2017). Roles of exosomes in cardioprotection. Eur Heart J 38, 1372-1379.

BERGMANN, O., ZDUNEK, S., FELKER, A., SALEHPOUR, M., ALKASS, K., BERNARD, S., SJOSTROM, S. L., SZEWCZYKOWSKA, M., JACKOWSKA, T., DOS REMEDIOS, C., MALM, T., ANDRA, M., JASHARI, R., NYENGAARD, J. R., POSSNERT, G., JOVINGE, S., DRUID, H. \& FRISEN, J. (2015). Dynamics of Cell Generation and Turnover in the Human Heart. Cell 161, 1566-1575. 
BRUCE, A., ALEXANDER, J., JULIAN, L., MARTIN, R., KEITH, R. \& PETER, W. (2002). Molecular Biology of the Cell. Garland Science, New York.

BRUNNER, F., BRAS-SILVA, C., CERDEIRA, A. S. \& LEITE-MOREIRA, A. F. (2006). Cardiovascular endothelins: essential regulators of cardiovascular homeostasis. Pharmacol Ther 111, 508-531.

BRYAN, N. S., FERNANDEZ, B. O., BAUER, S. M., GARCIA-SAURA, M. F., MILSOM, A. B., RASSAF, T., MALONEY, R. E., BHARTI, A., RODRIGUEZ, J. \& FEELISCH, M. (2005). Nitrite is a signaling molecule and regulator of gene expression in mammalian tissues. Nat Chem Biol 1, 290-297.

BRYAN, N. S. \& GRISHAM, M. B. (2007). Methods to detect nitric oxide and its metabolites in biological samples. Free Radic Biol Med 43, 645-657.

CHEN, H. H. \& BURNETT, J. C., JR. (1999). The natriuretic peptides in heart failure: diagnostic and therapeutic potentials. Proc Assoc Am Physicians 111, 406-416.

CIKES, M. \& SOLOMON, S. D. (2016). Beyond ejection fraction: an integrative approach for assessment of cardiac structure and function in heart failure. Eur Heart J 37, 1642-1650.

CLAYCOMB, W. C., LANSON, N. A., JR., STALLWORTH, B. S., EGELAND, D. B., DELCARPIO, J. B., BAHINSKI, A. \& IZZO, N. J., JR. (1998). HL-1 cells: a cardiac muscle cell line that contracts and retains phenotypic characteristics of the adult cardiomyocyte. Proc Natl Acad Sci U S A 95, 2979-2984.

CLERK, A., CULlingFORD, T. E., FULlER, S. J., GIRALDO, A., MARKOU, T., PIKKARAINEN, S. \& SUGDEN, P. H. (2007). Signaling pathways mediating cardiac myocyte gene expression in physiological and stress responses. J Cell Physiol 212, 311-322.

COPPIELLO, G., COLLANTES, M., SIREROL-PIQUER, M. S., VANDENWIJNGAERT, S., SCHOORS, S., SWINNEN, M., VANDERSMISSEN, I., HERIJGERS, P., TOPAL, B., VAN LOON, J., GOFFIN, J., PROSPER, F., CARMELIET, P., GARCIA-VERDUGO, J. M., JANSSENS, S., PENUELAS, I., ARANGUREN, X. L. \& LUTTUN, A. (2015). Meox2/Tcf15 heterodimers program the heart capillary endothelium for cardiac fatty acid uptake. Circulation 131, 815-826.

CORBAN, M. T., DUARTE-GARCIA, A., MCBANE, R. D., MATTESON, E. L., LERMAN, L. O. \& LERMAN, A. (2017). Antiphospholipid Syndrome: Role of Vascular Endothelial Cells and Implications for Risk Stratification and Targeted Therapeutics. J Am Coll Cardiol 69, 2317-2330.

CROZATIER, B. \& VENTURA-CLAPIER, R. (2015). Inhibition of hypertrophy, per se, may not be a good therapeutic strategy in ventricular pressure overload: other approaches could be more beneficial. Circulation 131, 1448-1457. 
DAVIES, P. F. (1995). Flow-mediated endothelial mechanotransduction. Physiol Rev 75, 519-560.

DE CATERINA, R., LIBBY, P., PENG, H. B., THANNICKAL, V. J., RAJAVASHISTH, T. B., GIMBRONE, M. A., JR., SHIN, W. S. \& LIAO, J. K. (1995). Nitric oxide decreases cytokine-induced endothelial activation. Nitric oxide selectively reduces endothelial expression of adhesion molecules and proinflammatory cytokines. J Clin Invest 96, 60-68.

DEMISSEI, B. G., POSTMUS, D., ClELAND, J. G., O'CONNOR, C. M., METRA, M., PONIKOWSKI, P., TEERLINK, J. R., COTTER, G., DAVISON, B. A., GIVERTZ, M. M., BLOOMFIELD, D. M., VAN VELDHUISEN, D. J., DITTRICH, H. C., HILLEGE, H. L. \& VOORS, A. A. (2017). Plasma biomarkers to predict or rule out early post-discharge events after hospitalization for acute heart failure. Eur J Heart Fail 19, 728-738.

DESHMANE, S. L., KREMLEV, S., AMINI, S. \& SAWAYA, B. E. (2009). Monocyte chemoattractant protein-1 (MCP-1): an overview. J Interferon Cytokine Res 29, 313-326.

DiMOPOUloS, K., DILleR, G. P., KOLTSIDA, E., PIJUAN-DOMENECH, A., PAPADOPOUlOU, S. A., BABU-NARAYAN, S. V., SALUKHE, T. V., PIEPOLI, M. F., POOLE-WILSON, P. A., BEST, N., FRANCIS, D. P. \& GATZOULIS, M. A. (2008). Prevalence, predictors, and prognostic value of renal dysfunction in adults with congenital heart disease. Circulation 117, 2320-2328.

DINARELLO, C. A. (2007). Historical insights into cytokines. Eur J Immunol 37 Suppl 1, S34-45.

DIWAN, A. \& DORN, G. W., 2ND (2007). Decompensation of cardiac hypertrophy: cellular mechanisms and novel therapeutic targets. Physiology (Bethesda) 22, 56-64.

EDELBERG, J. M., AIRD, W. C., WU, W., RAYBURN, H., MAMUYA, W. S., MERCOLA, M. \& ROSENBERG, R. D. (1998). PDGF mediates cardiac microvascular communication. J Clin Invest 102, 837-843.

EHL, N. F., KUHNE, M., BRINKERT, M., MULLER-BRAND, J. \& ZELLWEGER, M. J. (2011). Diabetes reduces left ventricular ejection fraction--irrespective of presence and extent of coronary artery disease. Eur J Endocrinol 165, 945-951.

ERKELENS, C. D., VAN DER WAL, H. H., DE JONG, B. M., ELTING, J. W., RENKEN, R., GERRITSEN, M., VAN LAAR, P. J., VAN DEURSEN, V. M., VAN DER MEER, P., VAN VELDHUISEN, D. J., VOORS, A. A. \& LUIJCKX, G. J. (2017). Dynamics of cerebral blood flow in patients with mild non-ischaemic heart failure. Eur J Heart Fail 19, 261-268.

FARAH, C., NASCIMENTO, A., BOLEA, G., MEYER, G., GAYRARD, S., LACAMPAGNE, A., CAZORLA, O. \& REBOUL, C. (2017). Key role of endothelium in the eNOS-dependent cardioprotection with exercise training. J Mol Cell Cardiol 102, 26-30.

FARHAT, N., MATOUK, C. C., MAMARBACHI, A. M., MARSDEN, P. A., ALLEN, B. G. \& THORIN, E. (2008). Activation of ETB receptors regulates the abundance of ET-1 mRNA in vascular endothelial 
cells. Br J Pharmacol 153, 1420-1431.

FEDERICO, C. (2010). Natriuretic Peptide system and cardiovascular disease. Heart Views 11, 10-15.

Flammer, A. J., ANDERSON, T., CELERMAJER, D. S., CREAGER, M. A., DEANFIELD, J., GANZ, P., HAMBURG, N. M., LUSCHER, T. F., SHECHTER, M., TADDEI, S., VITA, J. A. \& LERMAN, A. (2012). The assessment of endothelial function: from research into clinical practice. Circulation 126 , 753-767.

FLOREY (1966). The endothelial cell. Br Med J 2, 487-490.

FOLSE, R. \& BRAUNWALD, E. (1962). Determination of fraction of left ventricular volume ejected per beat and of ventricular end-diastolic and residual volumes. Experimental and clinical observations with a precordial dilution technic. Circulation 25, 674-685.

FONAROW, G. C. \& HSU, J. J. (2016). Left Ventricular Ejection Fraction: What Is "Normal"? JACC Heart Fail 4, 511-513.

FONSECA, C., SARMENTO, P. M., MINEZ, A., GONCALVES, E., COVAS, R., DIAS, A. R., PINA, M. J. \& CEIA, F. (2004). Comparative value of BNP and NT-proBNP in diagnosis of heart failure. Rev Port Cardiol 23, 979-991.

FORSTERMANN, U. \& SESSA, W. C. (2012). Nitric oxide synthases: regulation and function. Eur Heart J $33,829-837,837 a-837 d$.

FRANSSEN, C., CHEN, S., UNGER, A., KORKMAZ, H. I., DE KEULENAER, G. W., TSCHOPE, C., LEITE-MOREIRA, A. F., MUSTERS, R., NIESSEN, H. W., LINKE, W. A., PAULUS, W. J. \& HAMDANI, N. (2016). Myocardial Microvascular Inflammatory Endothelial Activation in Heart Failure With Preserved Ejection Fraction. JACC Heart Fail 4, 312-324.

FREDRIKSEN, P. M., VELDTMAN, G., HECHTER, S., THERRIEN, J., CHEN, A., WARSI, M. A., FREEMAN, M., LIU, P., SIU, S., THAULOW, E. \& WEBB, G. (2001). Aerobic capacity in adults with various congenital heart diseases. Am J Cardiol 87, 310-314.

FREY, N., KATUS, H. A., OLSON, E. N. \& HILL, J. A. (2004). Hypertrophy of the heart: a new therapeutic target? Circulation 109, 1580-1589.

FREY, N. \& OLSON, E. N. (2003). Cardiac hypertrophy: the good, the bad, and the ugly. Annu Rev Physiol 65, 45-79.

FROHLICH, E. D., APSTEIN, C., ChOBANIAN, A. V., DEVEREUX, R. B., DUSTAN, H. P., DZAU, V., FAUAD-TARAZI, F., HORAN, M. J., MARCUS, M., MASSIE, B. \& ET AL. (1992). The heart in hypertension. N Engl J Med 327, 998-1008. 
FUJITA, S., SHIMOJO, N., TERASAKI, F., OTSUKA, K., HOSOTANI, N., KOHDA, Y., TANAKA, T., NISHIOKA, T., YOSHIDA, T., HIROE, M., KITAURA, Y., ISHIZAKA, N. \& IMANAKA-YOSHIDA, K. (2013). Atrial natriuretic peptide exerts protective action against angiotensin II-induced cardiac remodeling by attenuating inflammation via endothelin-1/endothelin receptor $A$ cascade. Heart Vessels 28, 646-657.

FURCHGOTT, R. F. \& ZAWADZKI, J. V. (1980). The obligatory role of endothelial cells in the relaxation of arterial smooth muscle by acetylcholine. Nature $288,373-376$.

GENE ONTOLOGY, C. (2015). Gene Ontology Consortium: going forward. Nucleic Acids Res 43, D1049-56.

GEORGIOPOULOU, V. V., KALOGEROPOULOS, A. P., BORLAUG, B. A., GHEORGHIADE, M. \& BUTLER, J. (2013). Left ventricular dysfunction with pulmonary hypertension: Part 1: epidemiology, pathophysiology, and definitions. Circ Heart Fail 6, 344-354.

GIMBRONE, M. A., JR. (1987). Vascular endothelium: nature's blood-compatible container. Ann N Y Acad Sci 516, 5-11.

GIVVIMANI, S., QIPSHIDZE, N., TYAGI, N., MISHRA, P. K., SEN, U. \& TYAGI, S. C. (2011). Synergism between arrhythmia and hyperhomo-cysteinemia in structural heart disease. Int J Physiol Pathophysiol Pharmacol 3, 107-119.

GLADYSHEVA, I. P., WANG, D., MCNAMEE, R. A., HOUNG, A. K., MOHAMAD, A. A., FAN, T. M. \& REED, G. L. (2013). Corin overexpression improves cardiac function, heart failure, and survival in mice with dilated cardiomyopathy. Hypertension 61, 327-332.

GOTTLIEB, S. S., KUKIN, M. L., AHERN, D. \& PACKER, M. (1989). Prognostic importance of atrial natriuretic peptide in patients with chronic heart failure. J Am Coll Cardiol 13, 1534-1539.

GRANDE, D., GIOIA, M. I., TERLIZZESE, P. \& IACOVIELLO, M. (2017). Heart Failure and Kidney Disease. Adv Exp Med Biol 21.

GRANDI, A. M., LAURITA, E., SELVA, E., PIANTANIDA, E., IMPERIALE, D., GIOVANELLA, L., GUASTI, L. \& VENCO, A. (2004). Natriuretic peptides as markers of preclinical cardiac disease in obesity. Eur J Clin Invest 34, 342-348.

GREULICH, S., MAXHERA, B., VANDENPLAS, G., DE WIZA, D. H., SMIRIS, K., MUELLER, H., HEINRICHS, J., BLUMENSATT, M., CUVELIER, C., AKHYARI, P., RUIGE, J. B., OUWENS, D. M. \& ECKEL, J. (2012). Secretory products from epicardial adipose tissue of patients with type 2 diabetes mellitus induce cardiomyocyte dysfunction. Circulation 126, 2324-2334.

GROSSMAN, W., JONES, D. \& MCLAURIN, L. P. (1975). Wall stress and patterns of hypertrophy in the human left ventricle. J Clin Invest 56, 56-64. 
GUYTON, A. C. \& HALL, J. E. (2006). Textbook of medical physiology. Elsevier Inc, $11^{\text {th }}$ ed, Philadelphia, Pennsylvania.

HADDADZADEH, M. H., MAIYA, A. G., PADMAKUMAR, R., SHAD, B. \& MIRBOLOUK, F. (2011). Effect of exercise-based cardiac rehabilitation on ejection fraction in coronary artery disease patients: a randomized controlled trial. Heart Views 12, 51-57.

HE, K. L., DEORA, A. B., XIONG, H., LING, Q., WEKSLER, B. B., NIESVIZKY, R. \& HAJJAR, K. A. (2008). Endothelial cell annexin $A 2$ regulates polyubiquitination and degradation of its binding partner S100A10/p11. J Biol Chem 283, 19192-19200.

HEART OUTCOMES PREVENTION EVALUATION STUDY, I., YUSUF, S., SLEIGHT, P., POGUE, J., BOSCH, J., DAVIES, R. \& DAGENAIS, G. (2000). Effects of an angiotensin-converting-enzyme inhibitor, ramipril, on cardiovascular events in high-risk patients. N Engl J Med 342, 145-153.

HEDHLI, N., HUANG, Q., KALINOWSKI, A., PALMERI, M., HU, X., RUSSELL, R. R. \& RUSSELL, K. S. (2011). Endothelium-derived neuregulin protects the heart against ischemic injury. Circulation 123, 2254-2262.

HEISS, M., HELLSTROM, M., KALEN, M., MAY, T., WEBER, H., HECKER, M., AUGUSTIN, H. G. \& KORFF, T. (2015). Endothelial cell spheroids as a versatile tool to study angiogenesis in vitro. FASEB J $29,3076-3084$.

HERWIG, M. C., MULLER, K. M. \& MULLER, A. M. (2008). Endothelial VE-cadherin expression in human lungs. Pathol Res Pract 204, 725-730.

HOLOPAINEN, T., RASANEN, M., ANISIMOV, A., TUOMAINEN, T., ZHENG, W., TVOROGOV, D., HULMI, J. J., ANDERSSON, L. C., CENNI, B., TAVI, P., MERVAALA, E., KIVELA, R. \& ALITALO, K. (2015). Endothelial Bmx tyrosine kinase activity is essential for myocardial hypertrophy and remodeling. Proc Natl Acad Sci U S A 112, 13063-13068.

HONG, H. M., SONG, E. J., OH, E., KABIR, M. H., LEE, C. \& YOO, Y. S. (2011). Endothelin-1- and isoproterenol-induced differential protein expression and signaling pathway in $\mathrm{HL}-1$ cardiomyocytes. Proteomics 11, 283-297.

HOOD, W. P., JR., RACKLEY, C. E. \& ROLETT, E. L. (1968). Wall stress in the normal and hypertrophied human left ventricle. Am J Cardiol 22, 550-558.

HOWARD, C. M. \& BAUDINO, T. A. (2014). Dynamic cell-cell and cell-ECM interactions in the heart. J Mol Cell Cardiol 70, 19-26.

HSIEH, P. C., DAVIS, M. E., LISOWSKI, L. K. \& LEE, R. T. (2006). Endothelial-cardiomyocyte interactions in cardiac development and repair. Annu Rev Physiol 68, 51-66. 
HU, R., HUFFMAN, K. E., CHU, M., ZHANG, Y., MINNA, J. D. \& YU, Y. (2016). Quantitative Secretomic Analysis Identifies Extracellular Protein Factors That Modulate the Metastatic Phenotype of Non-Small Cell Lung Cancer. J Proteome Res 15, 477-486.

HU, W., ZHOU, P. H., ZHANG, X. B., XU, C. G. \& WANG, W. (2015). Plasma concentrations of adrenomedullin and natriuretic peptides in patients with essential hypertension. Exp Ther Med 9, 1901-1908.

HUANG, D. W., SHERMAN, B. T., TAN, Q., COLLINS, J. R., ALVORD, W. G., ROAYAEI, J., STEPHENS, R., BASELER, M. W., LANE, H. C. \& LEMPICKI, R. A. (2007). The DAVID Gene Functional Classification Tool: a novel biological module-centric algorithm to functionally analyze large gene lists. Genome Biol 8, R183.

HUANG, Z. P., CHEN, J., SEOK, H. Y., ZHANG, Z., KATAOKA, M., HU, X. \& WANG, D. Z. (2013). MicroRNA-22 regulates cardiac hypertrophy and remodeling in response to stress. Circ Res $112,1234-1243$.

HUNT, B. J. \& JURD, K. M. (1998). Endothelial cell activation. A central pathophysiological process. BMJ 316, 1328-1329.

IRVINE, J. C., CAO, N., GOSSAIN, S., ALEXANDER, A. E., LOVE, J. E., QIN, C., HOROWITZ, J. D., KEMP-HARPER, B. K. \& RITCHIE, R. H. (2013). HNO/cGMP-dependent antihypertrophic actions of isopropylamine-NONOate in neonatal rat cardiomyocytes: potential therapeutic advantages of HNO over NO. Am J Physiol Heart Circ Physiol 305, H365-377.

JABA, I. M., ZHUANG, Z. W., LI, N., JIANG, Y., MARTIN, K. A., SINUSAS, A. J., PAPADEMETRIS, X., SIMONS, M., SESSA, W. C., YOUNG, L. H. \& TIRZIU, D. (2013). NO triggers RGS4 degradation to coordinate angiogenesis and cardiomyocyte growth. J Clin Invest 123, 1718-1731.

JAIN, A., SCOTT, C. \& CHEN, H. H. (2017). The renal-cardiac connection in subjects with preserved ejection fraction: a population based study. ESC Heart Fail 4, 266-273.

JEN, H. L., YIN, W. H., CHEN, J. W. \& LIN, S. J. (2017). Endothelin-1-Induced Cell Hypertrophy in Cardiomyocytes is Improved by Fenofibrate: Possible Roles of Adiponectin. J Atheroscler Thromb 24, 508-517.

JIA, G., HABIBI, J., AROOR, A. R., HILL, M. A., DEMARCO, V. G., LEE, L. E., MA, L., BARRON, B. J., WHALEY-CONNELL, A. \& SOWERS, J. R. (2018). Enhanced endothelium epithelial sodium channel signaling prompts left ventricular diastolic dysfunction in obese female mice. Metabolism 78, 69-79.

KATO, J., KITAMURA, K., MATSUI, E., TANAKA, M., ISHIZAKA, Y., KITA, T., KANGAWA, K. \& ETO, T. (1999). Plasma adrenomedullin and natriuretic peptides in patients with essential or malignant hypertension. Hypertens Res 22, 61-65. 
KJELDSEN, S. E., DAHLOF, B., DEVEREUX, R. B., JULIUS, S., AURUP, P., EDELMAN, J., BEEVERS, G., DE FAIRE, U., FYHRQUIST, F., IBSEN, H., KRISTIANSON, K., LEDERBALLE-PEDERSEN, O., LINDHOLM, L. H., NIEMINEN, M. S., OMVIK, P., OPARIL, S., SNAPINN, S., WEDEL, H. \& GROUP, L. S. (2002). Effects of losartan on cardiovascular morbidity and mortality in patients with isolated systolic hypertension and left ventricular hypertrophy: a Losartan Intervention for Endpoint Reduction (LIFE) substudy. JAMA 288, 1491-1498.

KLEINBONGARD, P., DEJAM, A., LAUER, T., RASSAF, T., SCHINDLER, A., PICKER, O., SCHEEREN, T., GODECKE, A., SCHRADER, J., SCHULZ, R., HEUSCH, G., SCHAUB, G. A., BRYAN, N. S., FEELISCH, M. \& KELM, M. (2003). Plasma nitrite reflects constitutive nitric oxide synthase activity in mammals. Free Radic Biol Med 35, 790-796.

KOREN, M. J., DEVEREUX, R. B., CASALE, P. N., SAVAGE, D. D. \& LARAGH, J. H. (1991). Relation of left ventricular mass and geometry to morbidity and mortality in uncomplicated essential hypertension. Ann Intern Med 114, 345-352.

LEURGANS, T. M., BLOKSGAARD, M., BREWER, J. R., BAGATOLLI, L. A., FREDGART, M. H., ROSENSTAND, K., HANSEN, M. L., RASMUSSEN, L. M., IRMUKHAMEDOV, A. \& DE MEY, J. G. (2016). Endothelin-1 shifts the mediator of bradykinin-induced relaxation from NO to $\mathrm{H2} \mathrm{O2}$ in resistance arteries from patients with cardiovascular disease. $\mathrm{Br} J$ Pharmacol 173, 1653-1664.

LEVY, D., GARRISON, R. J., SAVAGE, D. D., KANNEL, W. B. \& CASTELLI, W. P. (1990). Prognostic implications of echocardiographically determined left ventricular mass in the Framingham Heart Study. N Engl J Med 322, 1561-1566.

LILYANNA, S., PEH, M. T., LIEW, O. W., WANG, P., MOORE, P. K., RICHARDS, A. M. \& MARTINEZ, E. C. (2015). GYY4137 attenuates remodeling, preserves cardiac function and modulates the natriuretic peptide response to ischemia. J Mol Cell Cardiol 87, 27-37.

LIU, H., CHEN, B. \& LILLY, B. (2008). Fibroblasts potentiate blood vessel formation partially through secreted factor TIMP-1. Angiogenesis 11, 223-234.

LIU, W., DENG, J., DING, W., WANG, G., SHEN, Y., ZHENG, J., ZHANG, X., LUO, Y., LV, C., WANG, Y., CHEN, L., YAN, D., BOUDREAU, R. L., SONG, L. S. \& LIU, J. (2017). Decreased KCNE2 Expression Participates in the Development of Cardiac Hypertrophy by Regulation of Calcineurin-NFAT (Nuclear Factor of Activated T Cells) and Mitogen-Activated Protein Kinase Pathways. Circ Heart Fail 10(6), e003960.

LUI, G. K., SAIDI, A., BHATT, A. B., BURCHILL, L. J., DEEN, J. F., EARING, M. G., GEWITZ, M., GINNS, J., KAY, J. D., KIM, Y. Y., KOVACS, A. H., KRIEGER, E. V., WU, F. M., YOO, S. J., AMERICAN HEART ASSOCIATION ADULT CONGENITAL HEART DISEASE COMMITTEE OF THE COUNCIL ON CLINICAL, C., COUNCIL ON CARDIOVASCULAR DISEASE IN THE, Y., COUNCIL ON CARDIOVASCULAR, R., INTERVENTION, COUNCIL ON QUALITY OF, C. \& OUTCOMES, R. (2017). 
Diagnosis and Management of Noncardiac Complications in Adults With Congenital Heart Disease: A Scientific Statement From the American Heart Association. Circulation 136, e348-e392.

LUKASZ, A., BEUTEL, G., KUMPERS, P., DENECKE, A., WESTHOFF-BLECK, M., SCHIEFFER, B., BAUERSACHS, J., KIELSTEIN, J. T. \& TUTAREL, O. (2013). Angiopoietin-2 in adults with congenital heart disease and heart failure. PLoS One 8, e66861.

MAMAlygA, M. L. \& MAMALYGA, L. M. (2017). Effect of Progressive Heart Failure on Cerebral Hemodynamics and Monoamine Metabolism in CNS. Bull Exp Biol Med 163, 307-312.

MARIAN, A. J. \& BRAUNWALD, E. (2017). Hypertrophic Cardiomyopathy: Genetics, Pathogenesis, Clinical Manifestations, Diagnosis, and Therapy. Circ Res 121, 749-770.

MILAM, K. E. \& PARIKH, S. M. (2015). The angiopoietin-Tie2 signaling axis in the vascular leakage of systemic inflammation. Tissue Barriers 3, e957508.

MOLDOBAEVA, A. \& WAGNER, E. M. (2002). Heterogeneity of bronchial endothelial cell permeability. Am J Physiol Lung Cell Mol Physiol 283, L520-7.

MOLLOVA, M., BERSELL, K., WALSH, S., SAVLA, J., DAS, L. T., PARK, S. Y., SILBERSTEIN, L. E., DOS REMEDIOS, C. G., GRAHAM, D., COLAN, S. \& KUHN, B. (2013). Cardiomyocyte proliferation contributes to heart growth in young humans. Proc Natl Acad Sci U S A 110, 1446-1451.

NADAR, S. K., BLANN, A., BEEVERS, D. G. \& LIP, G. Y. (2005). Abnormal angiopoietins 1\&2, angiopoietin receptor Tie-2 and vascular endothelial growth factor levels in hypertension: relationship to target organ damage [a sub-study of the Anglo-Scandinavian Cardiac Outcomes Trial (ASCOT)]. J Intern Med 258, 336-343.

NOIREAUD, J. \& ANDRIANTSITOHAINA, R. (2014). Recent insights in the paracrine modulation of cardiomyocyte contractility by cardiac endothelial cells. Biomed Res Int 2014, 923805.

NOlAN, D. J., GINSBerg, M., ISRAely, E., PALIKUQI, B., POUlOS, M. G., JAMES, D., DiNG, B. S., SCHACHTERLE, W., LIU, Y., ROSENWAKS, Z., BUTLER, J. M., XIANG, J., RAFII, A., SHIDO, K., RABBANY, S. Y., ELEMENTO, O. \& RAFII, S. (2013). Molecular signatures of tissue-specific microvascular endothelial cell heterogeneity in organ maintenance and regeneration. Dev Cell 26, 204-219.

OKA, T., AKAZAWA, H., NAITO, A. T. \& KOMURO, I. (2014). Angiogenesis and cardiac hypertrophy: maintenance of cardiac function and causative roles in heart failure. Circ Res 114, 565-571.

OliVETTI, G., CIGOLA, E., MAESTRI, R., CORRADI, D., LAGRASTA, C., GAMBERT, S. R. \& ANVERSA, P. (1996). Aging, cardiac hypertrophy and ischemic cardiomyopathy do not affect the proportion of mononucleated and multinucleated myocytes in the human heart. J Mol Cell 
Cardiol 28, 1463-1477.

PARODI, E. M. \& KUHN, B. (2014). Signalling between microvascular endothelium and cardiomyocytes through neuregulin. Cardiovasc Res 102, 194-204.

PATTON, K. K., ELLINOR, P. T., HECKBERT, S. R., CHRISTENSON, R. H., DEFILIPPI, C., GOTTDIENER, J. S. \& KRONMAL, R. A. (2009). N-terminal pro-B-type natriuretic peptide is a major predictor of the development of atrial fibrillation: the Cardiovascular Health Study. Circulation 120, 1768-1774.

PAULUS, W. J. \& TSCHOPE, C. (2013). A novel paradigm for heart failure with preserved ejection fraction: comorbidities drive myocardial dysfunction and remodeling through coronary microvascular endothelial inflammation. J Am Coll Cardiol 62, 263-271.

PenNa, C., tullio, F., femmino, S., RoCCA, C., ANgelone, T., Cerra, M. C., Gallo, M. P., GESMUNDO, I., FANCIULLI, A., BRIZZI, M. F., PAGLIARO, P., ALLOATTI, G. \& GRANATA, R. (2017). Obestatin regulates cardiovascular function and promotes cardioprotection through the nitric oxide pathway. J Cell Mol Med 21(12), 3670-3678.

PEYVANDI, F., GARAGIOLA, I. \& BARONCIANI, L. (2011). Role of von Willebrand factor in the haemostasis. Blood Transfus 9 Suppl 2, s3-8.

PINTO, A. R., ILINYKH, A., IVEY, M. J., KUWABARA, J. T., D'ANTONI, M. L., DEBUQUE, R., CHANDRAN, A., WANG, L., ARORA, K., ROSENTHAL, N. A. \& TALLQUIST, M. D. (2016). Revisiting Cardiac Cellular Composition. Circ Res 118, 400-409.

POBER, J. S. \& SESSA, W. C. (2007). Evolving functions of endothelial cells in inflammation. Nat Rev Immunol 7, 803-815.

POSS, J., UKENA, C., KINDERMANN, I., EHRLICH, P., FUERNAU, G., EWEN, S., MAHFOUD, F., KRIECHBAUM, S., BOHM, M. \& LINK, A. (2015). Angiopoietin-2 and outcome in patients with acute decompensated heart failure. Clin Res Cardiol 104, 380-387.

RADOVITS, T., OLAH, A., LUX, A., NEMETH, B. T., HIDI, L., BIRTALAN, E., KELLERMAYER, D., MATYAS, C., SZABO, G. \& MERKELY, B. (2013). Rat model of exercise-induced cardiac hypertrophy: hemodynamic characterization using left ventricular pressure-volume analysis. Am J Physiol Heart Circ Physiol 305, H124-34.

REDFIELD, M. M., RODEHEFFER, R. J., JACOBSEN, S. J., MAHONEY, D. W., BAILEY, K. R. \& BURNETT, J. C., JR. (2004). Plasma brain natriuretic peptide to detect preclinical ventricular systolic or diastolic dysfunction: a community-based study. Circulation 109, 3176-3181.

ROSE, B. A., YOKOTA, T., CHINTALGATTU, V., REN, S., IRUELA-ARISPE, L., KHAKOO, A. Y., MINAMISAWA, S. \& WANG, Y. (2017). Cardiac myocyte p38alpha kinase regulates angiogenesis via 
myocyte-endothelial cell cross-talk during stress-induced remodeling in the heart. J Biol Chem 292, 12787-12800.

RUBATTU, S., BIGATTI, G., EVANGELISTA, A., LANZANI, C., STANZIONE, R., ZAGATO, L., MANUNTA, P., MARCHITTI, S., VENTURELLI, V., BIANCHI, G., VOLPE, M. \& STELLA, P. (2006). Association of atrial natriuretic peptide and type a natriuretic peptide receptor gene polymorphisms with left ventricular mass in human essential hypertension. J Am Coll Cardiol 48, 499-505.

SAHA, K., CASE, R. \& WONG, P. K. (1992). A simple method of concentrating monoclonal antibodies from culture supernatant by ultrafiltration. J Immunol Methods 151, 307-308.

SANCHEZ, R., MACKENZIE, A., FARHAT, N., NGUYEN, T. D., STEWART, D. J., MERCIER, I., CALDERONE, A. \& THORIN, E. (2002). Endothelin B receptor-mediated regulation of endothelin-1 content and release in cultured porcine aorta endothelial cell. J Cardiovasc Pharmacol 39, 652-659.

SATTAYAPRASERT, P., NASSAL, D. M., WAN, X., DESCHENES, I. \& LAURITA, K. R. (2016). Mesenchymal stem cells suppress cardiac alternans by activation of PI3K mediated nitroso-redox pathway. J Mol Cell Cardiol 98, 138-145.

SCHIATTARELLA, G. G. \& HILL, J. A. (2015). Inhibition of hypertrophy is a good therapeutic strategy in ventricular pressure overload. Circulation 131, 1435-1447.

SEIDLMAYER, L. K., KUHN, J., BERBNER, A., ARIAS-LOZA, P. A., WILLIAMS, T., KASPAR, M., CZOLBE, M., KWONG, J. Q., MOLKENTIN, J. D., HEINZE, K. G., DEDKOVA, E. N. \& RITTER, O. (2016). Inositol 1,4,5-trisphosphate-mediated sarcoplasmic reticulum-mitochondrial crosstalk influences adenosine triphosphate production via mitochondrial $\mathrm{Ca2+}$ uptake through the mitochondrial ryanodine receptor in cardiac myocytes. Cardiovasc Res 112, 491-501.

SEMINA, E. V., RUBINA, K. A., SYSOEVA, V. Y., RUTKEVICH, P. N., KASHIRINA, N. M. \& TKACHUK, V. A. (2014). Novel mechanism regulating endothelial permeability via T-cadherin-dependent VE-cadherin phosphorylation and clathrin-mediated endocytosis. Mol Cell Biochem 387, 39-53.

SERGEEVA, I. A. \& CHRISTOFFELS, V. M. (2013). Regulation of expression of atrial and brain natriuretic peptide, biomarkers for heart development and disease. Biochim Biophys Acta 1832, 2403-2413.

SERGEV, O., RACZ, K., VARGA, I., KISS, R., FUTO, L., GUTKOWSKA, J. \& GLAZ, E. (1991). Dissociation of plasma atrial natriuretic peptide responses to upright posture and furosemide administration in patients with normal-, low renin essential hypertension and primary aldosteronism. Clin Exp Hypertens A 13, 409-423.

SHEN, D., TANG, J., HENSLEY, M. T., LI, T., CARANASOS, T. G., ZHANG, T., ZHANG, J. \& CHENG, K. (2016). Effects of Matrix Metalloproteinases on the Performance of Platelet Fibrin Gel Spiked With 
Cardiac Stem Cells in Heart Repair. Stem Cells Transl Med 5, 793-803.

SHIOJIMA, I., SATO, K., IZUMIYA, Y., SCHIEKOFER, S., ITO, M., LIAO, R., COLUCCI, W. S. \& WALSH, K. (2005). Disruption of coordinated cardiac hypertrophy and angiogenesis contributes to the transition to heart failure. J Clin Invest 115, 2108-2118.

SIEBER, M. \& BAUMGRASS, R. (2009). Novel inhibitors of the calcineurin/NFATc hub - alternatives to CsA and FK506? Cell Commun Signal 7, 25.

SIEVERT, W., TROTT, K. R., AZIMZADEH, O., TAPIO, S., ZITZELSBERGER, H. \& MULTHOFF, G. (2015). Late proliferating and inflammatory effects on murine microvascular heart and lung endothelial cells after irradiation. Radiother Oncol 117, 376-381.

SU, W. H., CHEN, H. I. \& JEN, C. J. (2002). Differential movements of VE-cadherin and PECAM-1 during transmigration of polymorphonuclear leukocytes through human umbilical vein endothelium. Blood 100, 3597-3603.

SUGAMURA, K. \& KEANEY, J. F., JR. (2011). Reactive oxygen species in cardiovascular disease. Free Radic Biol Med 51, 978-992.

SUKRITI, S., TAUSEEF, M., YAZBECK, P. \& MEHTA, D. (2014). Mechanisms regulating endothelial permeability. Pulm Circ 4, 535-551.

TABIT, C. E., CHEN, P., KIM, G. H., FEDSON, S. E., SAYER, G., COPLAN, M. J., JEEVANANDAM, V., URIEL, N. \& LIAO, J. K. (2016). Elevated Angiopoietin-2 Level in Patients With Continuous-Flow Left Ventricular Assist Devices Leads to Altered Angiogenesis and Is Associated With Higher Nonsurgical Bleeding. Circulation 134, 141-152.

TAKEDA, N. \& MANABE, I. (2011). Cellular Interplay between Cardiomyocytes and Nonmyocytes in Cardiac Remodeling. Int J Inflam 2011, 535241.

TORRES-COURCHOUD, I. \& CHEN, H. H. (2016). B-type natriuretic peptide and acute heart failure: Fluid homeostasis, biomarker and therapeutics. Rev Clin Esp 216, 393-398.

TRAUB, O. \& BERK, B. C. (1998). Laminar shear stress: mechanisms by which endothelial cells transduce an atheroprotective force. Arterioscler Thromb Vasc Biol 18, 677-685.

TSAI, S. H., LU, G., XU, X., REN, Y., HEIN, T. W. \& KUO, L. (2017). Enhanced endothelin-1/Rho-kinase signalling and coronary microvascular dysfunction in hypertensive myocardial hypertrophy. Cardiovasc Res 113, 1329-1337.

UUSIMAA, P., TOKOLA, H., YLITALO, A., VUOLTEENAHO, O., RUSKOAHO, H., RISTELI, J., LINNALUOTO, M., PEUHKURINEN, K. \& ANGLO-SCANDINAVIAN CARDIAC OUTCOMES TRIAL, I. (2004). Plasma B-type natriuretic peptide reflects left ventricular hypertrophy and diastolic function in 
hypertension. Int J Cardiol 97, 251-256.

VERMA, A., MERIS, A., SKALI, H., GHALI, J. K., ARNOLD, J. M., BOURGOUN, M., VELAZQUEZ, E. J., MCMURRAY, J. J., KOBER, L., PFEFFER, M. A., CALIFF, R. M. \& SOLOMON, S. D. (2008). Prognostic implications of left ventricular mass and geometry following myocardial infarction: the VALIANT (VALsartan In Acute myocardial iNfarcTion) Echocardiographic Study. JACC Cardiovasc Imaging 1, 582-591.

VIERO, C., WEgENER, S., SCHOLZ, A., RUPPENTHAL, S., TIAN, Q., TABELLION, W., KREINEST, M., LASCHKE, M. W., KAESTNER, L. \& LIPP, P. (2016). Endothelin-1-induced remodelling of murine adult ventricular myocytes. Cell Calcium 59, 41-53.

VILLARROYA-BELTRI, C., GUTIERREZ-VAZQUEZ, C., SANCHEZ-CABO, F., PEREZ-HERNANDEZ, D., VAZQUEZ, J., MARTIN-COFRECES, N., MARTINEZ-HERRERA, D. J., PASCUAL-MONTANO, A., MITTELBRUNN, M. \& SANCHEZ-MADRID, F. (2013). Sumoylated hnRNPA2B1 controls the sorting of miRNAs into exosomes through binding to specific motifs. Nat Commun 4, 2980.

WANG, K., JIANG, Z., WEBSTER, K. A., CHEN, J., HU, H., ZHOU, Y., ZHAO, J., WANG, L., WANG, Y., ZHONG, Z., NI, C., LI, Q., XIANG, C., ZHANG, L., WU, R., ZHU, W., YU, H., HU, X. \& WANG, J. (2017). Enhanced Cardioprotection by Human Endometrium Mesenchymal Stem Cells Driven by Exosomal MicroRNA-21. Stem Cells Transl Med 6, 209-222.

WANG, Y., TANG, Y., ZOU, Y., WANG, D., ZHU, L., TIAN, T., WANG, J., BAO, J., HUI, R., KANG, L., SONG, L. \& WANG, J. (2017). Plasma level of big endothelin-1 predicts the prognosis in patients with hypertrophic cardiomyopathy. Int J Cardiol 243, 283-289.

WATT, N. T., GAGE, M. C., PATEL, P. A., VISWAMBHARAN, H., SUKUMAR, P., GALLOWAY, S., YULDASHEVA, N. Y., IMRIE, H., WALKER, A. M., GRIFFIN, K. J., MAKAVA, N., SKROMNA, A., BRIDGE, K., BEECH, D. J., SCHURMANS, S., WHEATCROFT, S. B., KEARNEY, M. T. \& CUBBON, R. M. (2017). Endothelial SHIP2 Suppresses Nox2 NADPH Oxidase-Dependent Vascular Oxidative Stress, Endothelial Dysfunction and Systemic Insulin Resistance. Diabetes 66(11), 2808-2821.

WILLMS-KRETSCHMER, K., FLAX, M. H. \& COTRAN, R. S. (1967). The fine structure of the vascular response in hapten-specific delayed hypersensitivity and contact dermatitis. Lab Invest 17 , 334-349.

XU, F. P., CHEN, M. S., WANG, Y. Z., YI, Q., LIN, S. B., CHEN, A. F. \& LUO, J. D. (2004). Leptin induces hypertrophy via endothelin-1-reactive oxygen species pathway in cultured neonatal rat cardiomyocytes. Circulation 110, 1269-1275.

XU, M., LU, Y. P., HASAN, A. A. \& HOCHER, B. (2017). Plasma ET-1 Concentrations are Elevated in Patients with Hypertension - Meta-Analysis of Clinical Studies. Kidney Blood Press Res 42, 304-313. 
XUE, C., SOWDEN, M. \& BERK, B. C. (2017). Extracellular Cyclophilin A, Especially Acetylated, Causes Pulmonary Hypertension by Stimulating Endothelial Apoptosis, Redox Stress, and Inflammation. Arterioscler Thromb Vasc Biol 37, 1138-1146.

YANCY, C. W., JESSUP, M., BOZKURT, B., BUTLER, J., CASEY, D. E., JR., DRAZNER, M. H., FONAROW, G. C., GERACI, S. A., HORWICH, T., JANUZZI, J. L., JOHNSON, M. R., KASPER, E. K., LEVY, W. C., MASOUDI, F. A., MCBRIDE, P. E., MCMURRAY, J. J., MITCHELL, J. E., PETERSON, P. N., RIEGEL, B., SAM, F., STEVENSON, L. W., TANG, W. H., TSAI, E. J., WILKOFF, B. L., AMERICAN COLLEGE OF CARDIOLOGY, F. \& AMERICAN HEART ASSOCIATION TASK FORCE ON PRACTICE, G. (2013). 2013 ACCF/AHA guideline for the management of heart failure: a report of the American College of Cardiology Foundation/American Heart Association Task Force on Practice Guidelines. J Am Coll Cardiol 62, e147-239.

YANG, H. Y., CHENG, C. F., DJOKO, B., LIAN, W. S., TU, C. F., TSAI, M. T., CHEN, Y. H., CHEN, C. C., CHENG, C. J. \& YANG, R. B. (2007). Transgenic overexpression of the secreted, extracellular EGF-CUB domain-containing protein SCUBE3 induces cardiac hypertrophy in mice. Cardiovasc Res 75, 139-147.

YANG, Y., DEL RE, D. P., NAKANO, N., SCIARRETTA, S., ZHAI, P., PARK, J., SAYED, D., SHIRAKABE, A., MATSUSHIMA, S., PARK, Y., TIAN, B., ABDELLATIF, M. \& SADOSHIMA, J. (2015). miR-206 Mediates YAP-Induced Cardiac Hypertrophy and Survival. Circ Res 117, 891-904.

ZEISBERG, E. M., TARNAVSKI, O., ZEISBERG, M., DORFMAN, A. L., MCMULLEN, J. R., GUSTAFSSON, E., CHANDRAKER, A., YUAN, X., PU, W. T., ROBERTS, A. B., NEILSON, E. G., SAYEGH, M. H., IZUMO, S. \& KALLURI, R. (2007). Endothelial-to-mesenchymal transition contributes to cardiac fibrosis. Nat Med 13, 952-961.

ZHANG, C. (2008). The role of inflammatory cytokines in endothelial dysfunction. Basic Res Cardiol 103, 398-406.

ZHANG, J., LI, S., LI, L., LI, M., GUO, C., YAO, J. \& MI, S. (2015). Exosome and exosomal microRNA: trafficking, sorting, and function. Genomics Proteomics Bioinformatics 13, 17-24.

ZHANG, M. \& SHAH, A. M. (2014). ROS signalling between endothelial cells and cardiac cells. Cardiovasc Res 102, 249-257.

ZILE, M. R., GOTTDIENER, J. S., HETZEL, S. J., MCMURRAY, J. J., KOMAJDA, M., MCKELVIE, R., BAICU, C. F., MASSIE, B. M., CARSON, P. E. \& INVESTIGATORS, I. P. (2011). Prevalence and significance of alterations in cardiac structure and function in patients with heart failure and a preserved ejection fraction. Circulation 124, 2491-2501.

ZIMMERMANN, K., SCHEIBE, O., KOCOUREK, A., MUELICH, J., JURKIEWICZ, E. \& PFEIFER, A. (2011). Highly efficient concentration of lenti- and retroviral vector preparations by membrane adsorbers and ultrafiltration. BMC Biotechnol 11, 55. 


\section{Acknowledgements}

Firstly, I would like to express my sincere gratitude to Prof. Dr. Markus Hecker, for giving me the opportunity to pursue my $\mathrm{PhD}$ study in the Department of Cardiovascular Physiology, University of Heidelberg. I thank him for his consistent and fruitful supervision during my study. His constructive suggestions and useful comments during each lab meeting guided the project though these years.

I would like to thank my supervisors, PD Dr. Andreas H. Wagner and Dr. Nina D. Ullrich. They provided continuous support about experiment design, trouble shootings, data analysis, academic writing, and collaboration with others during the whole period of my study. Their profuse experience in science contributed a lot to the process of this project. I thank Prof. Dr. Thomas Korff and Dr. Oliver Drews, for their suggestions to the improvement of this project.

I am sincerely grateful for the excellent technical assistance from Franziska Mohr, Manuela Höfer and Nadine Schulz. I also would like to thank Dr. Sarawuth Wantha, Dr. Valentin Sottas, Anca Remes, Carl-Mattheis Wahl, Dr. Cheryl Sultan, Dr. Tanja Wiedenmann, Miruna Popa, Sebastian Lont, Christoph Hangel, Sibgha Tahir, Eda Demirel, Hanna Kuk, Felix Trogisch, Dr. Caroline Arnold, Dr. Cordula Rumig, Dr. Ivelina Kadiyska, Taslima Nahar, Renate Cattaruzza, Felicia Feiler, Barbara Richards, Dr. Gerd König and all other current and former colleagues.

Special thanks to Pegah Khamehgir-Silz, Dr. Thomas Ruppert, and Jing Yang for the excellent collaboration work and helpful assistance on mass spectrometry operation and data analysis.

My sincere thanks also go to all the friends I met in Mannheim and Heidelberg.

Last but the most important, I would like to express my greatest gratitude to my parents, for the constant support and warmest accompany in my life. 